\title{
Functional characterization and lineage analysis of broadly neutralizing human antibodies against dengue virus identified by single $B$ cell transcriptomics
}

Natasha D. Durham ${ }^{1^{*}}$, Aditi Agrawal ${ }^{1 *}$, Eric Waltari ${ }^{1}$, Derek Croote ${ }^{2}$, Fabio Zanini ${ }^{2+}$, Edgar Davidson $^{3}$, Mallorie Fouch ${ }^{3}$, Olivia Smith ${ }^{1}$, Esteban Carabajal ${ }^{1}$, John E. Pak ${ }^{1}$, Benjamin J. Doranz $^{3}$, Makeda Robinson ${ }^{4,5}$, Ana M. Sanz ${ }^{6}$, Ludwig L. Albornoz ${ }^{7}$, Fernando Rosso ${ }^{6,8}$, Shirit Einav $^{4,5}$, Stephen R. Quake ${ }^{1,2}$, Krista M. McCutcheon ${ }^{1}$, Leslie Goo ${ }^{1,9 \# \text {. }}$

${ }^{1}$ Chan Zuckerberg Biohub, San Francisco, United States

${ }^{2}$ Department of Bioengineering, Stanford University, Stanford, United States

${ }^{3}$ Integral Molecular, Inc., Philadelphia, United States

${ }^{4}$ Division of Infectious Diseases and Geographic Medicine, Department of Medicine, Stanford University School of Medicine, Stanford, United States

${ }^{5}$ Department of Microbiology and Immunology, Stanford University School of Medicine, Stanford, United States

${ }^{6}$ Clinical Research Center, Fundación Valle del Lili, Cali, Colombia

${ }^{7}$ Pathology and Laboratory Department, Fundación Valle del Lili, Cali, Colombia.

${ }^{8}$ Department of Internal Medicine, Division of Infectious Diseases, Fundación Valle del Lili, Cali, Colombia

${ }^{9}$ Fred Hutchinson Cancer Research Center, Seattle, United States

\section{${ }^{*}$ Equal contribution}

${ }^{\wedge}$ Current affiliation: Department of Microbiology and Physiological Systems, University of Massachusetts Medical School, Worcester, United States

${ }^{+}$Current affiliation: Lowy Cancer Research Center, University of New South Wales, Kensington, NSW, Australia

\#Corresponding author: lgoo@fredhutch.org

\footnotetext{
Abstract

Eliciting broadly neutralizing antibodies (bNAbs) against the four dengue virus serotypes (DENV1-4) that are spreading into new territories is an important goal of vaccine design. To delineate bNAb targets, we characterized 28 monoclonal antibodies belonging to expanded and hypermutated clonal families identified by transcriptomic analysis of single plasmablasts from DENV-infected individuals. Among these, we identified two somatically related bNAbs that potently neutralized DENV1-4. Mutagenesis studies revealed that the major recognition determinants of these bNAbs are in E protein domain I, distinct from the only known class of human bNAbs against flaviviruses with a well-defined epitope. B cell repertoire analysis from acute-phase peripheral blood suggested a memory origin and divergent somatic hypermutation pathways for these bNAbs, and a limited number of mutations was sufficient for neutralizing activity. Our study suggests multiple B cell evolutionary pathways leading to DENV bNAbs targeting a novel epitope that can be exploited for vaccine design.
} 


\section{Introduction}

Dengue virus (DENV) is an enveloped, positive-stranded RNA virus belonging to the Flavivirus genus, which includes clinically significant human pathogens such as Yellow Fever virus (YFV), Japanese encephalitis virus (JEV), West Nile virus (WNV), and Zika virus (ZIKV). DENV is transmitted to humans via Aedes mosquitoes, whose global distribution places half of the world's population at risk for infection (Kraemer et al., 2019; Messina et al., 2019). Each year, the four phylogenetically and antigenically distinct DENV serotypes (DENV1-4) cause approximately 400 million infections (Bhatt et al., 2013). Additionally, increased global trade, connectivity, and climate change have fueled the expansion of DENV1-4 into new territories (Kraemer et al., 2019; Messina et al., 2014).

Approximately $20 \%$ of DENV-infected individuals develop a mild febrile illness, of which $5 \%$ to $20 \%$ progress to potentially fatal severe disease, characterized by bleeding, plasma leakage, shock, and organ failure (Guzman \& Harris, 2015; Khursheed et al., 2013; Thein, Leo, Lee, Sun, \& Lye, 2011). Epidemiological studies have shown that pre-existing antibodies from a primary DENV infection are a risk factor for severe disease following subsequent infection with a heterologous DENV serotype (Katzelnick et al., 2017; Salje et al., 2018; Sangkawibha et al., 1984). This is partly attributed to the prevalence of cross-reactive antibodies from the initial infection that can bind, but not neutralize the secondary heterologous virus. Instead, these nonneutralizing antibodies have the potential to facilitate viral uptake into Fc gamma receptorexpressing target cells in a process known as antibody-dependent enhancement (ADE) (Guzman \& Harris, 2015; Halstead, 2014). Recent studies of clinical cohorts demonstrated that the risk of severe disease following secondary infection is greatest when pre-existing titers of cross-reactive antibodies fall within a narrow, intermediate range (Katzelnick et al., 2017; Salje et al., 2018). To limit the potential for ADE, an effective vaccine must therefore elicit durable and potent neutralizing antibodies of high titer against DENV1-4 simultaneously. However, the viral and host determinants leading to such bNAbs against flaviviruses are poorly understood.

All of the leading DENV vaccine candidates in clinical development are based on a tetravalent strategy (Scherwitzl, Mongkolsapaja, \& Screaton, 2017), which assumes that the use of representative viral strains from each serotype will elicit a balanced and potent polyclonal antibody response to minimize the risk of ADE. However, the suboptimal efficacy and safety profile of a recently licensed DENV vaccine has been partly attributed to its inability to generate a balanced neutralizing antibody response to all four serotypes (Hadinegoro et al., 2015). Additionally, there may be important antigenic differences between circulating and lab-adapted strains (Lim et al., 2019; Raut et al., 2019), as well as among strains even within a given serotype (Bell, Katzelnick, \& Bedford, 2019; Katzelnick et al., 2015). Antigenic mismatch between vaccine and circulating strains impacted vaccine efficacy (Juraska et al., 2018), highlighting the importance of rational selection of vaccine components. An alternative strategy, largely exemplified by vaccine development efforts for HIV (Kwong \& Mascola, 2018) and respiratory syncytial virus (RSV) (Crank et al., 2019), relies on identifying antibodies with desirable properties and precisely defining their epitopes to guide epitope-based vaccine design (Graham, Gilman, \& McLellan, 2019). For antigenically diverse viruses such as DENV, a 
conserved epitope-based vaccine strategy to elicit a broad and potent monoclonal neutralizing antibody response could mitigate the challenge of selecting representative vaccine strains.

The main target of flavivirus neutralizing antibodies is the envelope (E) glycoprotein, which consists of three structural domains (DI, DII, DIII), and is anchored to the viral membrane via a helical stem and transmembrane domain. The $\mathrm{E}$ proteins direct many steps of the flavivirus life cycle, including entry, fusion, and assembly of new virus particles (Pierson \& Diamond, 2012). Flaviviruses bud into the endoplasmic reticulum lumen as immature particles with a spiky surface on which $E$ proteins associate into sixty heterotrimers with a chaperone protein, prM (Prasad et al., 2017; Y. Zhang et al., 2003; Y. Zhang, Kaufmann, Chipman, Kuhn, \& Rossmann, 2007). Within the low pH environment of the trans-golgi network, E proteins undergo conformational changes that allow furin-mediated cleavage of prM (Yu et al., 2008), resulting in the release of mature infectious virions with a smooth surface densely coated with ninety $\mathrm{E}$ homodimers (Kostyuchenko et al., 2016; Kuhn et al., 2002; Mukhopadhyay, Kim, Chipman, Rossmann, \& Kuhn, 2003; Sirohi et al., 2016; X. Zhang et al., 2013). The dense arrangement of $E$ proteins on the virion surface is important for antigenicity, as many potently neutralizing human antibodies against flaviviruses target quaternary epitopes spanning multiple $E$ proteins (de Alwis et al., 2012; Hasan et al., 2017; Kaufmann et al., 2010; Rouvinski et al., 2015; Teoh et al., 2012).

Recent advances in monoclonal antibody isolation and characterization (Boonyaratanakornkit \& Taylor, 2019; Corti \& Lanzavecchia, 2014) have accelerated the identification of bNAbs, including those against flaviviruses. Examples include antibodies d488 (Li et al., 2019) and m366 (Hu et al., 2019), which were cloned from B cells of rhesus macaques receiving an experimental DENV vaccine and from healthy flavivirus-naive humans, respectively, and mAb DM25-3, which was isolated from a mouse immunized with a mature form of DENV2 virus-like particles ((Shen et al., 2018). Although these antibodies are cross-reactive against DENV1-4, they demonstrated only moderate potency. E protein residues involved in d488 binding lie at the interface of the M protein and the E protein ectodomain (Li et al., 2019), while those for m366.6 binding appear to be located at the dimerization interface between DII and DIII (Hu et al., 2019). Residue W101 within the DII fusion loop was identified to be important for recognition by mAb DM25-3 (Shen et al., 2018). Attempts to engineer mouse antibodies with increased breadth and potency against DENV1-4 have also been described (Deng et al., 2011; Shi et al., 2016; Tharakaraman et al., 2013).

Only a few naturally occurring human bNAbs against flaviviruses have been characterized. Many of these antibodies target epitopes consisting of the DII fusion loop as well as the adjacent bc loop in DII in some cases (Smith et al., 2013; Tsai et al., 2013; Xu et al., 2017). Although antibodies recognizing the highly conserved fusion loop can demonstrate broad reactivity to all DENV serotypes and related flaviviruses, their neutralizing potency is often limited due to this epitope being largely inaccessible, especially on mature virions (Cherrier et al., 2009; Nelson et al., 2008; Shen et al., 2018; Stiasny, Kiermayr, Holzmann, \& Heinz, 2006). To date, the most well-characterized class of human antibodies with broad and potent neutralizing activity against flaviviruses targets a conserved, quaternary epitope spanning both 
E monomeric subunits within the dimer. A subset of these $E$ dimer epitope (EDE)-specific bNAbs potently neutralize not only DENV1-4, but also ZIKV, owing to the high conservation of the EDE, which overlaps the prM binding site on $E$ (Barba-Spaeth et al., 2016; Dejnirattisai et al., 2015; Rouvinski et al., 2015). The exciting discovery of the EDE class of bNAbs highlights the potential for an epitope-focused flavivirus vaccine strategy.

As multiple specificities are likely required to provide maximum coverage of diverse circulating viral variants (Bell et al., 2019; Doria-Rose et al., 2012; Goo, Jalalian-Lechak, Richardson, \& Overbaugh, 2012; Katzelnick et al., 2015; Keeffe et al., 2018; Kong et al., 2015), in this study, we aimed to define novel sites on the flavivirus $E$ protein that can be targeted by bNAbs. By characterizing 28 monoclonal antibodies from the plasmablasts of two DENV-infected individuals, we identified $\mathrm{J} 8$ and $\mathrm{J} 9$, clonally related bNAbs that neutralized DENV1-4 in the low picomolar range. The major recognition determinants for J8 and J9 were in E protein DI, distinct from previously characterized bNAbs. Analysis of the corresponding B cell repertoire revealed divergent evolution of $\mathrm{J} 8$ and $\mathrm{J} 9$, suggesting multiple evolutionary pathways to generate bNAbs within this lineage. Our work identifies both viral and host determinants of the development of DENV bNAbs that can guide immunogen design and evaluation.

\section{Results}

\section{Identification of cross-reactive neutralizing antibodies from clonally expanded plasmablasts of DENV-infected individuals}

We previously profiled the single-cell transcriptomics of peripheral blood mononuclear cells (PBMCs) from six dengue patients and four healthy individuals (Zanini et al., 2018). In two DENV-infected patients (013 and 020), we identified 15 clonal families comprising a total of 38 unique paired heavy $(\mathrm{VH})$ and light $(\mathrm{VL})$ chain lgG1 plasmablast sequences, some of which were hypermutated $(1.67 \%$ to $10.77 \%$ for $\mathrm{VH}, 0.67 \%$ to $7.22 \%$ for VL; Figure S1). One clonal family (CF) included members found in both individuals (antibodies B10, M1, and D8 from CF1, Figure S1), suggesting convergent evolution, which has been described for the antibody response to distinct viruses, including flaviviruses (Parameswaran et al., 2013; Robbiani et al., 2017), Ebola virus (Davis et al., 2019) and HIV (Scheid et al., 2011; Wu et al., 2011). To functionally characterize these monoclonal antibodies (mAbs), we successfully cloned 36 paired $\mathrm{VH}$ and VL sequences into expression vectors, and transfected mammalian cells for small scale (96-well) recombinant IgG1 production. We detected secreted IgG in the transfection supernatants for 28 of 36 mAbs, which were tested for binding to DENV2 recombinant soluble $E$ protein (rE) and reporter virus particles (RVPs), as well as for neutralizing activity against a panel of flavivirus RVPs, including DENV1-4, ZIKV, and WNV (Figure S1). Seventeen of 28 mAbs bound to either DENV2 rE $(n=1)$, or RVPs $(n=7)$, or both $(n=9)$. None of the mAbs neutralized ZIKV, but all 28 neutralized at least one DENV serotype, $21 \mathrm{mAbs}$ neutralized two or more DENV serotypes, and one mAb neutralized WNV in addition to DENV.

\section{Binding profile of mAbs}

For further characterization, we selected six mAbs for larger scale production and IgG purification based on their ability to neutralize at least four of the six RVPs tested. These 
included two mAb clonal variants found in both patients (B10 from patient 020 and M1 from patient 013 ), two $(\mathrm{C} 4, \mathrm{J9})$ and one (L8) patient 013 and patient $020 \mathrm{mAbs}$, respectively, that neutralized DENV1-4, and the only mAb that neutralized WNV (I7 from patient 020$)$. We first confirmed binding activity at a single antibody concentration $(5 \mu \mathrm{g} / \mathrm{ml})$ by ELISA. Consistent with our pilot screen using crude IgG-containing supernatant (Figure S1), 17, M1, B10, and L8 bound to both rE and RVPs, while C4 and J9 bound to RVPs only (Figure 1A \& B), suggesting that these mAbs target epitopes preferentially displayed on the intact virion. As incubation at higher temperatures has been shown to improve exposure of some epitopes (Dowd, Jost, Durbin, Whitehead, \& Pierson, 2011; Lok et al., 2008; Sukupolvi-Petty et al., 2013), we performed the ELISA at both ambient temperature and $37^{\circ} \mathrm{C}$. For most antibodies, incubation at $37^{\circ} \mathrm{C}$ resulted in a modest but consistent increase in RVP binding (Figure 1B). To evaluate the relative binding of the mAbs to rE and RVP, we also performed a dose-responsive indirect ELISA at ambient temperature (Figure $1 \mathrm{C}$ ). Binding curves revealed robust binding of $\mathrm{mAbs} L 8, \mathrm{~B} 10, \mathrm{M} 1$, and 17 to DENV2 rE (EC50 range of 0.4 to $23 \mathrm{ng} / \mathrm{ml}$ ) while $\mathrm{J9}$, C4 and the EDE mAbs C10 and B7 displayed little to no binding to $\mathrm{rE}$ even at high antibody concentrations (up to $200 \mu \mathrm{g} / \mathrm{mL}$ ). All mAbs showed binding to DENV2 RVP to varying extents, with relatively high EC50 values for J9 (200 ng/ml), J8 (213 ng/ml), and C4 (1200 ng/ml), suggesting limited affinity maturation (Figure 1D).

\section{Neutralization potency of mAbs}

We next performed dose-response neutralization assays to obtain $\mathrm{IC}_{50}$ values (mAb concentration at which $50 \%$ of virus infectivity was inhibited). Antibodies M1, B10, and L8 displayed modest (average $\mathrm{IC}_{50}$ range of 379 to $796 \mathrm{ng} / \mathrm{ml}$ ) and incomplete neutralization of DENV1-4, with $\sim 10 \%$ to $\sim 50 \%$ infectivity persisting at the highest mAb concentration tested (10 $\mu \mathrm{g} / \mathrm{ml}$ ) (Figures $2 \mathrm{~A}-\mathrm{B}$ ). Incomplete neutralization is commonly observed for cross-reactive DII fusion loop-specific antibodies, and likely represents structurally heterogeneous virions on which the epitope is not displayed frequently enough for antibodies to bind at a stoichiometry sufficient for neutralization (Nelson et al., 2008; Pierson et al., 2007). Antibody 17 displayed an unusual neutralization profile as it did not neutralize DENV4, and its potency against DENV1-3 was lower than that against the more antigenically distant WNV. Although mAb C4 completely neutralized DENV1-4, it did so with modest potency, especially against DENV4 $\left(\mathrm{IC}_{50}>1000\right.$ $\mathrm{ng} / \mathrm{ml}$ ). The most potent $\mathrm{mAb}$ we identified was $\mathrm{J9}$, which despite relatively weak binding (Figure 1), completely neutralized DENV1-4 with average $I C_{50}$ values of $6 \mathrm{ng} / \mathrm{ml}, 30 \mathrm{ng} / \mathrm{ml}, 15 \mathrm{ng} / \mathrm{ml}$, and $39 \mathrm{ng} / \mathrm{ml}$, respectively. A previously characterized subgroup of the EDE class of bNAbs, which includes mAb EDE1 C10 can neutralize not only DENV1-4, but also ZIKV (Barba-Spaeth et al., 2016). J9 showed a high specificity for DENV, with no activity against ZIKV, and up to 60-fold greater potency against some DENV serotypes compared to EDE1 C10 (Figure 2B). Depending on the serotype, the average neutralization potency of J9 against DENV1-4 was also up to 15-fold higher than that of bNAb EDE2 B7, which belongs to another EDE subgroup with poor neutralizing activity against ZIKV (Barba-Spaeth et al., 2016).

The broad and potent neutralizing activity of $\mathrm{J9}$ prompted us to re-evaluate our pilot results obtained for J8, a somatic variant with no binding or neutralizing activity in our screen with crude IgG-containing supernatant (Figure S1). When we repeated the cloning, expression, and 
purification of J8 IgG, we observed similar binding (Figure 1) and neutralization (Figure 2) profiles to J9. When tested as Fab fragments, J9 and J8 were still able to potently neutralize DENV, unlike C4 and EDE1 C10, which failed to achieve 50\% neutralization at the highest $\mathrm{mAb}$ concentration tested (Figure S2). J9 and J8 also potently neutralized contemporary DENV1-4 isolates with $\mathrm{IC}_{50}$ values $<50 \mathrm{ng} / \mathrm{ml}$ (Figure S3). Additionally, in contrast to C4 and the crossreactive DII fusion loop-specific mouse mAb E60 (Goo, VanBlargan, Dowd, Diamond, \& Pierson, 2017; Nelson et al., 2008; Oliphant et al., 2006), but similar to EDE bNAbs (Dejnirattisai et al., 2015), J9 and J8 potently neutralized DENV regardless of virion maturation state (Figure S4), which can indirectly modulate epitope exposure (Cherrier et al., 2009; Goo et al., 2019; Nelson et al., 2008) and has been shown to be distinct among circulating versus labadapted strains (Raut et al., 2019). We also tested the ability of mAbs to mediate neutralization after virus attachment to cells, which is characteristic of many potently neutralizing antibodies against flaviviruses (Goo et al., 2019; Nybakken et al., 2005; Sukupolvi-Petty et al., 2010; Vogt et al., 2009; Xu et al., 2017). When added after virus attachment to Raji-DCSIGNR cells, C4 failed to inhibit $40-50 \%$ of infection at the highest $\mathrm{mAb}$ concentration tested $(300 \mu \mathrm{g} / \mathrm{ml})$ (Figure 3). In contrast, J9, J8, and EDE1 C10 potently inhibited DENV2 infection both pre- and postvirus attachment to cells.

\section{ADE potential of mAbs}

In vitro, antibodies can mediate ADE of infection in cells expressing Fc gamma receptor (FcyR) at sub-neutralizing concentrations (Pierson et al., 2007). Recent studies in humans have also demonstrated that the risk of severe dengue disease following secondary infection is greatest within a range of intermediate titers of pre-existing DENV-specific antibodies, while higher titers are protective against symptomatic infection (Katzelnick et al., 2017; Salje et al., 2018). Thus, eliciting potently neutralizing antibodies is desirable to limit the concentration range within which ADE can occur. We measured the ADE potential of a subset of the mAbs identified above in K562 cells, which have been used extensively to study ADE of flaviviruses as they express FcyR and are poorly permissive for infection in the absence of antibody (Littaua, Kurane, \& Ennis, 1990). As expected, all DENV-specific mAbs mediated ADE of DENV2 infection to varying extents (Figure S5). We measured the antibody concentration at which the highest level of ADE was observed (peak enhancement titer). Consistent with their high neutralization potencies, the average peak enhancement titer of $\mathrm{J9}$ and J8 for DENV2 (3 ng/ml) was approximately 27 -fold and 480-fold lower than that of mAbs EDE1 C10 (80 ng/ml) and C4 (1467 $\mathrm{ng} / \mathrm{ml}$ ), respectively (Figures S5A and S5D). For J9, J8, and EDE bNAbs, DENV2 neutralization occurred beyond the peak enhancement titer, with no infectivity observed at high antibody concentrations. In contrast, for C4 and L8, which neutralized DENV relatively weakly (Figure 1), ADE of DENV2 was still detected at the highest concentration $(10 \mu \mathrm{g} / \mathrm{ml})$ tested (Figure S5A). Even at high concentrations, L8 also mediated ADE of ZIKV (Figure S5B) and WNV (Figure $\mathrm{S} 5 \mathrm{C}$ ), suggesting binding, but not neutralizing activity against these viruses (Figure 1). Consistent with their ability to recognize ZIKV, EDE bNAbs enhanced ZIKV infection at subneutralizing concentrations (Figure S5B). J9 and J8 did not facilitate ADE of ZIKV nor WNV infection, suggesting lack of binding to these flaviviruses. Given their high neutralization potencies against DENV1-4, J9 and J8 represent desirable antibodies to elicit as their ADE 
potential is restricted to a narrow range of low antibody concentrations, beyond which neutralization is observed.

\section{Epitope specificity of mAbs}

To identify amino acid residues required for mAb recognition, we screened a shotgun alaninescanning mutagenesis library of DENV2 $\mathrm{E}$ protein variants for $\mathrm{mAb}$ binding by flow cytometry (Davidson \& Doranz, 2014). MAb binding profiles to this entire library are summarized in Table S1. MAbs M1 and L8 demonstrated loss of binding to variants encoding W101A and F108A mutations within the DII fusion loop (Figure 4A). Similar to a subset of previously described fusion loop-specific antibodies (Cherrier et al., 2009; Smith et al., 2013; Tsai et al., 2013), M1 recognition also depended on residue $\mathrm{G} 106$ within the fusion loop and residue 75 on the adjacent bc loop (Figure 4A). Specificity for the fusion loop epitope likely contributes to the inability of these mAbs to neutralize completely, even at high concentrations (Figures $2 A-B$ ), as previously described (Dowd et al., 2011; Nelson et al., 2008). The 17 epitope involved DII residues Q256 and G266 (Figure 4B), which are conserved among many flaviviruses (indicated by yellow squares in Figure S6A alignment) and are important for recognition by the recently described cross-reactive mAb (d448) isolated from vaccinated rhesus macaques ( $\mathrm{Li}$ et al., 2019). Unlike 17, d448 neutralized DENV4, but not WNV (Li et al., 2019). Despite testing different temperature and $\mathrm{pH}$ conditions, we did not detect $\mathrm{C} 4$ binding to WT DENV2 in this flow cytometry-based assay (data not shown) and were thus unable to screen against the mutant library. For J9, most E protein mutations that reduced binding by $>80 \%$ relative to WT (shown in bold in Table S1) were found in DI (R2, I4, K47, S145, H149, N153, T155), but G102 within DII fusion loop and DII N242, as well as DIII N366 were also important (Figure 4C). These mutations minimally affected EDE1 C10 binding (Figure 4C).

For further epitope mapping of $\mathrm{J9}$, one of the most potent bNAbs we identified, we first attempted to select for neutralization escape viral variants but were unsuccessful after six serial passages in cell culture under mAb selection pressure. We noted that J9 neutralized DENV1-4 but not ZIKV (Figure 1). As an alternative epitope mapping approach, we generated a panel of DENV2 RVP variants encoding individual mutations at solvent accessible $E$ protein residues on the mature DENV virion that are identical or chemically conserved across representative DENV1-4 strains but differ from ZIKV (Figure S6A). These residues in DENV2 $16681 \mathrm{E}$ were substituted for analogous residues in ZIKV H/PF/2013. We also included a subset of alanine mutants identified by our binding screen to confirm their importance for neutralization. In total, we generated 34 DENV2 RVP variants encoding individual mutations throughout the E protein (Figure S6B); 31 of these variants retained sufficient infectivity (Figure S7) for neutralization studies. Most individual mutations displayed minimal (<2-fold) effects on J9 neutralization potency (Figure S8A). Two DI mutations, K47T and V151T resulted in a modest 4-fold increase in $\mathrm{IC}_{50}$ (Figure S8A). Consistent with our binding screen, we confirmed that mutation at residue $\mathrm{N} 153$ or T155, each of which results in a loss of a potential N-linked glycosylation site, abrogated $\mathrm{J} 9$ neutralization, while mutation at $\mathrm{N} 242$ resulted in a 5-fold reduction in potency (Figures S8A). Although our binding screen suggested that individual G102A and S145A mutations contributed to $\mathrm{J} 9$ recognition, they had limited effects ( 2-fold) on neutralization potency (Figure S8A). 
Because we observed only modest effects with single mutations, we next generated DENV2 RVPs encoding the K47T and V151T mutations in combination, as well as 8 additional pairs of mutations at a subset of the above 34 residues selected based on their proximity to each other on the E dimer structure (Figure S6C). Seven of 8 DENV2 RVP variants encoding paired mutations retained infectivity (Figure S7). Five combinations of paired mutations displayed similarly modest (up to 4-fold) effects on $\mathrm{J} 9$ neutralization potency as when these mutations were tested individually (Figure S8A). However, in combination, K47T+V151T reduced J9 potency by almost 100 -fold. In combination with the F279S mutation in DI, K47T also resulted in a 16-fold average reduction in $\mathrm{J9}$ potency (Figure S8A). Figures 5A-B highlight key residues that reduced $\mathrm{J} 9$ neutralization potency, either alone or in combination, as identified from our screen against the entire panel of single and double mutants (Figure S8).

As seen for $\mathrm{J9}$, individual mutations at residues N153 and N155, which together encode a potential $\mathrm{N}$-linked glycosylation site, abrogated the neutralizing activity of the somatically related bNAb, J8 (Figure 5C). To varying extents, a similar set of individual and paired mutations that reduced $\mathrm{J} 9$ neutralization potency, including V151T, N242A, K47T+V151T, and H149S+V151T, also reduced $\mathrm{J} 8$ and C4 neutralization potency (Figures 5C-D). However, individual mutations at some DII and DIII residues that did not impact J9 neutralization potency (Figure S8A) did modestly increase resistance to neutralization by J8 (Figure S8B) and C4 (Figure S8C), respectively by 4- to 7-fold. Interestingly, the V151T mutation alone or in combination with either K47T or H149S increased neutralization potency of EDE1 C10 by 25 -fold (Figure 5E). These mutations had minimal (<2-fold) effects on the neutralizing activity of EDE2 B7 (Figure 5F) as well as patient 013 polyclonal serum (Figure S9), suggesting that they did not globally alter antigenicity. As previously shown (Dejnirattisai et al., 2015; Rouvinski et al., 2015), mutation at residue N153 or N155 improved and disrupted EDE1 C10 and EDE2 B7 recognition, respectively (Figures $5 \mathrm{E}-\mathrm{F}$ ). Overall, these results suggest that the recognition determinants of $\mathrm{J} 9, \mathrm{~J} 8$, and $\mathrm{C} 4$, are distinct from those targeted by EDE-specific and other previously characterized bNAbs against DENV1-4 (Dejnirattisai et al., 2015; Hu et al., 2019; Li et al., 2019; Smith et al., 2013; Tsai et al., 2013; Xu et al., 2017).

\section{Lineage analysis reveals memory origin and divergent evolution of bNAbs}

To gain insight into the development of bNAbs J9 and J8, we processed PBMCs of patient 013 (from which these bNAbs were identified) obtained four days post-fever onset, and performed next generation sequencing (NGS) of the $B$ cell receptor (BCR) repertoire. This patient experienced acute secondary infection with DENV4 (Zanini et al., 2018). Given its greater junctional diversity compared to light chain, we focused our analysis on the heavy chain repertoire, which is sufficient to identify clonal relationships (Zhou \& Kleinstein, 2019). We have recently shown that PBMC stimulation in a polyclonal, BCR-independent manner can selectively expand antigen-specific memory B cells (Waltari, McGeever, Friedland, Kim, \& McCutcheon, 2019). Accordingly, we obtained 8-fold more unique VH sequences from stimulated PBMCs with a greater representation of IgG over IgM clonal families compared to unstimulated PBMCs (Table S2). Compared to previously described healthy BCR repertoire data (Waltari et al., 2019), VH1-69, VH3-30, VH3-30-3, VH4-34, VH4-39 and VH4-59 were the most dominant 
across both unstimulated and stimulated PBMC VH families in patient 013 (average > $>5 \%$ of repertoire; Figure S10).

We found 579 and $43,179 \mathrm{VH}$ sequences related to J9/J8 in unstimulated and stimulated PBMCs, respectively $(0.4 \%$ and $3.5 \%$ of total reads, respectively, Table S3). For lineage construction (Figure 6A), we included sequences that met one of three criteria: 1) highest numbers of unique molecular identifier (UMI) counts (>35 in PBMC repertoire and $>150$ in stimulated PBMC repertoire IgG sequences and $>15$ in IgA sequences), 2 ) $<5 \%$ somatic hypermutation, or 3) $97 \%$ identity to $\mathrm{J} 9$ or $\mathrm{J} 8$. The $\mathrm{J} 9 / \mathrm{J} 8$ lineage derived from recombination of IGHV1-69 with IGHD2-2 and IGHJ5 with no CDRH3 insertions or deletions (Figure 6B). The majority of the clonal family members were of the $\lg _{1}$ subtype, with no IgM identified having a UMI count $>2$ and only a small percentage of $\lg A$ ( $1.8 \%$ of stimulated PBMC relatives; Figure $6 \mathrm{~A}$, triangles).

We identified clones with a $100 \%$ match at the nucleotide (nt) level to J9 and J8 in the stimulated PBMC repertoire (UMI counts of 9 and 14, respectively), and related clones identical in both unstimulated and stimulated PBMC repertoires throughout the various branches of the lineage (branch tips labeled J, Q, M, N and $P$ in Figure 6A). Overall, the repertoire showed a rapid expansion of class switched $\lg \mathrm{G}$ with numerous nt point mutations from germline $\mathrm{VH}$, strongly suggesting both J8 (27 nt) and J9 (28 nt) plasmablasts derived from memory B cells from a prior infection, consistent with previous studies (Priyamvada et al., 2016; Xu et al., 2016). Among this acute-phase repertoire, we did observe less mutated IgG clones A (3 nt), B (5 nt), and $C(5 \mathrm{nt})$ early in the lineage (Figure 6A ), which could represent antibodies derived from a de novo immune response, or from less mutated memory clones. Finally, the divergent evolution of $\mathrm{J} 9$ and $\mathrm{J} 8$ suggested multiple somatic hypermutation pathways within this lineage leading to bNAbs.

\section{VH and VL maturation contributes to broadly neutralizing activity}

As described above, J8 and J9 VH derived from V-D-J recombination of IGHV1-69 with IGHD22 and IGHJ5. Although we did not analyze the light chain repertoires, both J8 and J9 used the same founder germline IGKV3-11 and IGKJ2 genes with identical CDR lengths and no convergent mutations from germline (Figure 6C). To investigate the contribution of somatic hypermutation (SHM) on broadly neutralizing activity, we generated a panel of recombinant IgG variants, confirmed proper folding (Figure S11), and tested them for neutralizing activity. As expected, recombinant $\mathrm{J} 8$ and $\mathrm{J} 9 \mathrm{lgGs}$ expressing fully germline $\mathrm{VH}$ and VL had no neutralizing activity (Figures 7A-D). Similarly, J8 and J9 IgG expressing germline VH paired with the corresponding mature VL, and vice versa, did not neutralize DENV1-4, suggesting that both $\mathrm{VH}$ and VL SHM contributed to neutralizing activity.

Several mutations occurred early in the J8/J9 lineage, including CDR-H2 I53F, CDR-H3 T99A/P and $\mathrm{D} 100 \mathrm{cH}$ (clones labeled $\mathrm{A}, \mathrm{B}$, and $\mathrm{C}$ in Figure 6A, and alignments in Figure 6B), and were retained throughout the continued $\mathrm{VH}$ somatic hypermutation. To investigate the $\mathrm{VH}$ SHM requirements for broadly neutralizing activity, we generated "J9 5mut" and "J8 5mut" variants containing the above three early $\mathrm{VH}$ mutations (I53F, T99P, D100cH) and two additional CDR$\mathrm{H} 2$ mutations (Q61D, K62N) common across different lineage branches (Figures 6A and 6B). We paired J8 and J9 5mut VH with the corresponding mature VL to generate recombinant IgGs. These five CDR-H2 and CDR-H3 mutations were sufficient for broadly neutralizing activity of J8 against DENV1-4 (Figures 7A-D) and of J9 against DENV1 and DENV2 only (Figures 7A-B). Compared to fully mature J9, J9 5mut displayed reduced neutralization potency against DENV3 and DENV4 (Figures 7C-D), suggesting that additional J9 VH mutations were required for 
neutralization of these viruses. J9 VL mutations also played a role in neutralization of DENV3 and DENV4 as chimeric IgG expressing J9 heavy chain with J8 light chain displayed less potent neutralization of these viruses (Figures 7C-D). Finally, although the FR2 of J9 VH contained a glycine insertion not present in related clones (Figure 6B), this insertion was not necessary for neutralizing activity (Figure 7A-D).

\section{Discussion}

A safe and effective vaccine to protect against DENV remains elusive, largely due to the challenge of eliciting antibodies that can potently neutralize all four viral serotypes simultaneously to minimize the risk of ADE. For antigenically diverse viruses, more than one antibody specificity may be required to provide optimal coverage of diverse circulating variants (Bell et al., 2019; Doria-Rose et al., 2012; Goo et al., 2012; Katzelnick et al., 2015; Keeffe et al., 2018; Kong et al., 2015). Although cross-reactive antibodies against flaviviruses have been described, very few display potent neutralizing activity (Barba-Spaeth et al., 2016; Dejnirattisai et al., 2015; Xu et al., 2017). The epitope for one of these bNAbs (SiGN-3C) is not well defined but involves 2 residues within DII fusion loop and one in DIII (Xu et al., 2017). Detailed epitope mapping studies have been performed only for the EDE class of bNAbs, which recognize a quaternary epitope spanning both monomers within the E protein dimer (Barba-Spaeth et al., 2016; Rouvinski et al., 2015). This epitope involves five main regions on the $E$ protein: $b$ strand, fusion loop, and ij loop on DII; glycan loop on DI; and the DIII A strand. In this study, we functionally characterized $28 \mathrm{mAbs}$ identified to be clonally expanded and somatically hypermutated by transcriptomic analyses of single plasmablasts from two individuals acutely infected with DENV (Zanini et al., 2018). Among these, we identified bNAbs J9 and J8, which potently neutralized all four DENV serotypes and recognize an epitope with major determinants in DI. The location of residues important for $\mathrm{J9}$ and J8 recognition (Figure 5A), and the ability of these bNAbs to bind virus particles but not soluble E protein (Figure 1) suggest a quaternary epitope. Alternatively, the epitope may be localized to the $E$ monomer, but is preferentially displayed on virus particles, as previously described for a DENV1-specific mAb (Fibriansah et al., 2014). Nevertheless, our epitope mapping results demonstrated that the recognition determinants for J9/J8 are distinct from EDE bNAbs because E protein mutations that reduced neutralization potency of $\mathrm{J} 9 / \mathrm{J} 8$ either increased or did not alter neutralization potency of EDE1 and EDE2 antibodies, respectively (Figure 5). Thus, our study defines a new vulnerable site on the DENV E protein that can be exploited for immunogen design to elicit bNAbs.

A common strategy to isolate and characterize virus-specific mAbs involves sorting hundreds of single B cells from immune donors followed by reverse-transcription (RT)-PCR to isolate paired VH/VL genes for recombinant IgG production and functional characterization (Dejnirattisai et al., 2015; Robbiani et al., 2017; Rogers et al., 2017). In some cases, memory B cells that specifically bind viral antigens are first enriched by staining with fluorescently labeled antigen (Robbiani et al., 2017; Rogers et al., 2017; Scheid et al., 2009; Woda \& Mathew, 2015; Wu et al., 2010). Alternatively, single B cells are cultured, and secreted antibodies are directly screened for function (Walker et al., 2009). Although these methods have successfully identified many human bNAbs, including those against flaviviruses (Dejnirattisai et al., 2015; Smith et al., 2013; Tsai et al., 2013; Xu et al., 2012; Xu et al., 2017), they involve labor intensive steps. Instead of screening a large panel of candidate antibodies, we leveraged transcriptomic 
analyses of single plasmablasts from acute secondary DENV infection to focus our screen on clonally expanded and somatically hypermutated B cells (Zanini et al., 2018), which are likely to encode antigen-specific and affinity matured antibodies. Using this approach, we successfully identified highly potent mAbs capable of neutralizing all four DENV serotypes. It is unclear whether this bioinformatics-based approach to identify DENV bNAbs is fortuitous as acute DENV infection has been shown to induce a rapid and massive expansion of plasmablasts, many of which can neutralize multiple DENV serotypes (Priyamvada et al., 2016; Wrammert et al., 2012; Xu et al., 2012), or whether it is applicable to the rapid identification of highly functional antibodies against other viruses.

$\mathrm{J} 9$ and J8 are somatic IgG variants isolated from the same patient (013) who had an acute secondary infection with DENV4 (Zanini et al., 2018). NGS of the B cell repertoire and phylogenetic analysis of the J9/J8 lineage revealed divergent evolution of these bNAbs (Figure $6 \mathrm{~A}$ ), suggesting multiple SHM pathways to generate bNAbs against the $\mathrm{J} 9 / \mathrm{J} 8$ epitope, which is encouraging for vaccine design. Antibody lineage divergence and parallel evolution leading to multiple bNAbs within the same individual has also been described in the context of HIV infection (MacLeod et al., 2016). J9 and J8 bNAbs derived from IGVH1-69 and IGVK3-11 germline genes. Consistent with a previous study of DENV-infected individuals (Appanna et al., 2016), many of the DENV-specific mAbs originating from plasmablasts of patient 013 also derived from IGVH1-69 (Table S3), which is commonly used among bNAbs against other viruses such as influenza and Hepatitis C virus (Chen, Tzarum, Wilson, \& Law, 2019). Many of these bNAbs can achieve neutralization breadth and potency with limited SHM (Lingwood et al., 2012; Tzarum et al., 2019). Despite a moderately high degree of SHM for J8 VH (9.9\% at the nucleotide level, Figure S1), five early amino acid mutations in CDR-H2 and CDR-H3 were sufficient for neutralization breadth and potency (Figure 7). As the paired VL had a low (1.4\%) level of SHM, this observation suggests a relatively limited maturation pathway to a highly functional antibody.

To our knowledge, all human bNAbs against flaviviruses identified in the context of natural infection so far, including $\mathrm{J} 9$ and $\mathrm{J} 8$, were isolated from plasmablasts of individuals sequentially exposed to at least two different DENV serotypes (Dejnirattisai et al., 2015; Xu et al., 2012; Zanini et al., 2018). Sequential infection with heterologous DENV serotypes or HIV strains has been shown to broaden and strengthen the polyclonal neutralizing antibody response (Cortez, Odem-Davis, McClelland, Jaoko, \& Overbaugh, 2012; Patel et al., 2017; Tsai et al., 2015; Tsai et al., 2013). One proposed model is that low affinity, cross-reactive antibody secreting B-cell clones elicited by primary DENV exposure are reactivated during secondary infection to undergo further affinity maturation resulting in antibodies with more broad and potent neutralizing activity (Patel et al., 2017). Although the relatively high level of SHM already present in $\mathrm{J} 9$ and $\mathrm{J} 8$ at day 4 post-fever onset following secondary DENV infection suggests a recall response, repertoire analysis from earlier time points would be required to determine whether the memory B cell clones from which these bNAbs were derived underwent further SHM to achieve neutralization breadth and potency. 
It is also unclear whether the specificities and functions of plasmablast-derived mAbs present during acute infection confer long-lived protection from infection and pathogenesis. Interestingly, despite the presence of plasmablast-derived bNAbs such as $\mathrm{J} 9$ and $\mathrm{J} 8$, and those belonging to the EDE class during acute secondary infection, the donors from which these antibodies were isolated subsequently developed severe dengue disease (Dejnirattisai et al., 2015; Zanini et al., 2018). Indeed, the rapid and massive plasmablast activation following acute DENV infection is coincident with the onset of severe symptoms and has been proposed to contribute to immunopathology (Wrammert et al., 2012). Alternatively, despite broad and potent in vitro neutralizing activity against a surrogate panel of DENV1-4 strains, these bNAbs may not efficiently neutralize circulating infecting strains. Finally, it is possible that these bNAbs make up a minor component of the overall polyclonal antibody response, as supported by our finding that J9/J8-like mAbs minimally contribute to the overall neutralizing activity of patient 013 serum (Figure S9). Moreover, BCR repertoire analysis revealed that though expanded, the J9/J8 clonal family is not the largest in this donor (Table S3), at least not in the acute phase sample tested. The complex interplay among $B$ cells and antibodies of different specificities and functions present in sera, and their impact on immunity and pathogenesis warrant further study.

\section{Acknowledgements}

We thank the cohort participants and staff; Ted Pierson for providing Raji-DCSIGNR cells and constructs for RVP production; Anna Sellas, Gorica Margulis, Esther Ho, and Purnima Ravisankar for lab management and support; Peter Kim and Don Ganem for helpful discussion; Erick Matsen and Duncan Ralph for valuable comments on the manuscript.

Molecular graphics and analyses of the DENV2 E dimer were performed with UCSF Chimera, developed by the Resource for Biocomputing, Visualization, and Informatics at the University of California, San Francisco, with support from NIH P41-GM103311.

This work was funded by the Chan Zuckerberg Biohub (NDD, AA, EW, FZ, OS, EC, JEP, SRQ, KMM, LG); NSF Graduate Research Fellowship and the Kou-I Yeh Stanford Graduate Fellowship (DC); Catalyst Award from Dr. Ralph \& Marian Falk Medical Research Trust and the Stanford Bio-X Interdisciplinary Initiatives Seed Grants Program (SE); Stanford Advanced Residency Training at Stanford Fellowship Program (MR); NIH contract HHSN272201400058C (BJD); and Fred Hutchinson Cancer Research Center (LG).

\section{Competing interests}

FZ, DC, MR, LG, SRQ, SH, KMM, and EW are inventors of the following patent application, which is co-owned by the Chan Zuckerberg Biohub and Stanford University: PCT patent application entitled ANTIBODIES AGAINST DENGUE VIRUS AND RELATED METHODS, Serial no. PCT/US2019/045427, filed August 7, 2019. 


\section{Methods}

\section{Patient samples}

The study was approved by the Stanford University Administrative Panel on Human Subjects in Medical Research (Protocol \#35460) and the Fundación Valle del Lili Ethics committee in biomedical research (Cali,Colombia). All subjects, their parents, or legal guardians provided written informed consent, and subjects between 6 to 17 years of age and older provided assent. We collected blood samples from individuals who presented with symptoms compatible with dengue between 2016 and 2017 to the Fundación Valle del Lili in Cali, Colombia. Cohort details have been previously described (Zanini et al., 2018).

\section{Monoclonal antibodies}

Plasmablast-derived variable heavy or light chain sequences (Zanini et al., 2018) were synthesized as gene fragments (Genewiz, San Francisco, CA; Integrated DNA Technologies, Coralville, IA) to include at least a 15 basepair overlap with the 5' signal sequence and 3' constant region of our human IgG1, kappa or lambda expression vectors described elsewhere (Waltari et al., 2019). For pilot ELISAs and neutralization assays using crude IgG-containing supernatant, paired heavy and light chain plasmids for each mAb were expressed in Expi293F cells (Cat\# A14527, ThermoFisher Scientific, Waltham, MA) in a 96-well format. IgG levels were quantified by ELISA as described (Waltari et al., 2019). Antibodies with crude IgG expression levels $<0.5 \mathrm{ng} / \mathrm{mL}$ were excluded from further characterization. Antibodies selected for in-depth characterization (J9, J8, C4, B10, M1, L8 and I7), as well as control mAbs EDE1 C10

(Dejnirattisai et al., 2015), EDE2 B7 (Dejnirattisai et al., 2015), CR4354 (Kaufmann et al., 2010) were expressed by transient transfection of Expi-CHO-S cells (Cat\# A29129; ThermoFisher Scientific). Variable heavy and light chain sequences of the above control mAbs used for gene synthesis and cloning into expression vectors were based on PDB IDs 4UT9, 4UT6, and 3N9G, respectively. Cell culture supernatant was clarified by centrifugation at $3900 \mathrm{xg}$ for $30 \mathrm{~min}$ at $4^{\circ} \mathrm{C}$, passed through a $0.22 \mu \mathrm{m}$ filter, and IgG was purified on MabSelect SuRe resin (Cat\# 175438-01; GE Healthcare, Chicago, IL). Other control mAbs used in this study were obtained commercially: Anti-Dengue Virus Type II Antibody, clone 3H5-1 (Cat\# MAB8702; Millipore Sigma, Burlington, MA); Flavivirus group antigen Antibody (D1-4G2-4-15 (4G2)) (Cat\# NBP252709-0.2mg; Novus Biologicals, Centennial, CO).

\section{Cells}

Expi293F cells (Cat\# A14527; ThermoFisher Scientific) were cultured in Expi293 Expression Medium (Cat\# A1435101; ThermoFisher Scientific) according to the manufacturer's instructions. Expi-CHO-S Cells (Cat\# A29127; ThermoFisher Scientific) were cultured in ExpiCHO Expression Medium (Cat\# A2910001; ThermoFisher Scientific). HEK-293T/17 cells (ATCC CRL-11268) were maintained in DMEM (Cat\# 11965118; ThermoFisher Scientific) supplemented with 10\% fetal bovine serum (Cat\# FB-11; Omega Scientific, Inc.) and 100U/mL penicillin-streptomycin (Cat\# 15140-122; ThermoFisher Scientific). Raji cells stably expressing DCSIGNR (Raji-DCSIGNR) (Davis et al., 2006) (provided by Ted Pierson, NIH) and K562 cells (ATCC Cat\# CCL-243) were maintained in RPMI 1640 supplemented with GlutaMAX (Cat\# 72400-047; ThermoFisher Scientific), 10\% FBS and 100U/mL penicillin-streptomycin. All cells 
were maintained at $37^{\circ} \mathrm{C}$ in $5 \% \mathrm{CO}_{2}$ unless otherwise stated. C6/36 cells (ATCC CRL-1660) were maintained in EMEM (ATCC Cat\# 30-2003) supplemented with $10 \%$ FBS at $30^{\circ} \mathrm{C}$ in $5 \%$ $\mathrm{CO}_{2}$.

\section{Production of reporter virus particles (RVPs)}

RVPs were produced by co-transfection of HEK-293T/17 cells with (i) a plasmid expressing a WNV subgenomic replicon encoding GFP in place of structural genes (Pierson et al., 2006), and (ii) a plasmid encoding C-prM-E structural genes from the following viruses: DENV1 Western Pacific (WP) (Ansarah-Sobrinho, Nelson, Jost, Whitehead, \& Pierson, 2008), DENV2 16681 (Ansarah-Sobrinho et al., 2008), WNV NY99 (Pierson et al., 2006), and ZIKV H/PF/2013 (Dowd et al., 2016). Briefly, $8 \times 10^{\wedge} 5 \mathrm{HEK}-293 \mathrm{~T} / 17$ cells pre-plated in a 6-well plate were cotransfected with a mass ratio of 1:3 replicon:C-prM-E plasmids using Lipofectamine 3000 (Cat\# L3000-015; ThermoFisher Scientific). Four hours post-transfection, media was replaced with low-glucose DMEM (Cat\# 12320-032; ThermoFisher Scientific) containing 10\% FBS and $100 \mathrm{U} / \mathrm{mL}$ penicillin-streptomycin (i.e. low-glucose DMEM complete) and cells were transferred to $30^{\circ} \mathrm{C}$ in $5 \% \mathrm{CO}_{2}$. RVP-containing supernatant was harvested at 3,4 , and 5 days posttransfection, passed through a $0.22 \mu \mathrm{m}$ filter, pooled, and stored at $-80^{\circ} \mathrm{C}$. DENV3 strain CH53489 RVPs (Cat\# RVP-301; Integral Molecular, Philadelphia, PA) and DENV4 strain TVP360 RVPs (Cat\# RVP-401; Integral Molecular) were obtained commercially. RVPs with increased efficiency of prM cleavage were produced as above by co-transfecting plasmids encoding the replicon, structural genes, and human furin (provided by Ted Pierson, NIH) at a 1:3:1 mass ratio. Where indicated, RVPs were concentrated by ultracentrifugation through $20 \%$ sucrose at $164,000 \mathrm{xg}$ for $4 \mathrm{~h}$ at $4^{\circ} \mathrm{C}$, resuspended in HNE buffer $(5 \mathrm{mM} \mathrm{HEPES}, 150 \mathrm{mM} \mathrm{NaCl}$, $0.1 \mathrm{mM}$ EDTA, $\mathrm{pH} 7.4$ ), and stored at $-80^{\circ} \mathrm{C}$.

Infectious titers of RVPs were determined by infection of Raji-DCSIGNR cells. At $48 \mathrm{~h}$ postinfection, cells were fixed in 2\% paraformaldehyde (Cat\# 15714S; Electron Microscopy Sciences, Hatfield, PA), and GFP positive cells quantified by flow cytometry (Intellicyt iQue Screener PLUS, Sartorius AG, Gottingen, Germany).

Production, titer and neutralization of fully infectious contemporary DENV1-4 isolates The following DENV contemporary strains were used to infect C6/36 cells: DENV1 UIS 998 (Cat\# NR-49713; BEI), DENV2 US/BID-V594/2006 (Cat\# NR-43280; BEI), DENV3/US/BIDV1043/2006 (Cat\# NR-43282; BEI), DENV4 Strain UIS497 (Cat\# NR-49724; BEI). Viruscontaining supernatant was collected at days 2-7 post-infection, filtered, and stored at $-80^{\circ} \mathrm{C}$. Infectious titer was determined on Raji-DCSIGNR cells. At $48 \mathrm{~h}$ post-infection, intracellular staining was performed using BD Cytofix/Cytoperm Solution Kit (Cat\# 554714; BD Biosciences, San Jose, CA) according to the manufacturer's instructions. Mouse mAb 4G2 conjugated to Alexa Fluor 488 (Cat\# A20181; Thermo Fisher Scientific) was used for intracellular staining to detect infected cells by flow cytometry (Intellicyt iQue Screener PLUS, Sartorius AG).

Neutralization assays were performed as described below, using intracellular staining with Alexa Fluor 488-conjugated 4G2 to detect infected cells.

\section{Generation of E protein variants}


The DENV2 16681 C-prM-E expression construct (Ansarah-Sobrinho et al., 2008) was used as a template for site-directed mutagenesis using the Pfu Ultra DNA polymerase system (Cat\# 600380; Agilent Technologies, Santa Clara, CA) and primers generated by QuikChange $\mathbb{}$ Primer Design (Agilent Technologies). The entire C-prM-E region was sequenced (Quintara, San Francisco, CA) to confirm the presence of the desired mutation(s).

\section{Shotgun mutagenesis epitope mapping}

A DENV2 strain 16681 prM/E expression construct was subjected to high-throughput shotgun mutagenesis to generate a comprehensive mutation library, with each prM/E polyprotein residue mutated to alanine (with alanine residues to serine). In total, 559 DENV2 mutants were generated (99.6\% coverage of the prM/E protein), sequence confirmed, and arrayed into 384well plates (one mutation per well). For mAb library screening, plasmids encoding the DENV protein variants were transfected individually into human HEK-293T cells and allowed to express for $22 \mathrm{~h}$ before fixing cells in $4 \%$ paraformaldehyde (Electron Microscopy Sciences), and permeabilizing with $0.1 \%(\mathrm{w} / \mathrm{v})$ saponin (Sigma-Aldrich, St. Louis, MA) in PBS plus calcium and magnesium (PBS++). Cells were incubated with purified $\mathrm{mAbs}(0.1-2.0 \mu \mathrm{g} / \mathrm{mL})$ diluted in $10 \%$ NGS (Sigma-Aldrich) / 0.1\% saponin, pH 9.0. MAb J9 was screened in unfixed cells that had been co-transfected with the prM/E library and furin expression plasmids, to decrease levels of prM in the cells. Before screening, the optimal concentration was determined for each antibody, using an independent immunofluorescence titration curve against wild-type prM/E to ensure that signals were within the linear range of detection and that signal exceeded background by at least 5-fold. Antibodies were detected using $3.75 \mu \mathrm{g} / \mathrm{mL}$ Alexa Fluor 488conjugated secondary antibody (Jackson ImmunoResearch, West Grove, PA) in 10\% NGS / $0.1 \%$ saponin. Cells were washed three times with PBS $++/ 0.1 \%$ saponin followed by 2 washes in PBS. Mean cellular fluorescence was detected using a high throughput flow cytometer (Intellicyt iQue Screener Plus, Sartorius AG). Antibody reactivity against each mutant protein clone was calculated relative to reactivity with wild-type $\mathrm{prM} / \mathrm{E}$, by subtracting the signal from mock-transfected controls and normalizing to the signal from wild-type protein-transfected controls. The entire library data for each mAb was compared to the equivalent data from control mAbs. Mutations were identified as critical to the mAb epitope if they did not support reactivity of the test $\mathrm{mAb}(<20 \%$ of reactivity to WT prM/E) but supported reactivity of appropriate control antibodies ( $>70 \%$ of reactivity to WT prM/E). This counter-screen strategy facilitates the exclusion of DENV prM/E protein mutants that are mis-folded or have an expression defect (Davidson \& Doranz, 2014; Paes et al., 2009).

\section{ELISA}

High-binding 96-well plates (Cat\# CLS3361; Millipore Sigma, Burlington, MA) were either coated directly with $500 \mathrm{ng} /$ well of recombinant DENV2 $16681 \mathrm{E}$ protein (Cat\# DENV2-ENV-500; The Native Antigen Company, Oxford, UK) or with $300 \mathrm{ng} /$ well of murine mAb 4G2 for capture of concentrated and partially purified RVPs. Recombinant E or capture mAb was added in $100 \mu \mathrm{l}$ 1X PBS and incubated at $4^{\circ} \mathrm{C}$ overnight. The following day, $300 \mu 1 \%$ BSA in PBS blocking buffer (Cat\# B0101; Teknova, Hollister, CA) was added for $1 \mathrm{~h}$ either at room temperature (RT) or $37^{\circ} \mathrm{C}$. Plates were subsequently washed 6 times using $300 \mu \mathrm{PBST}$ (PBS $+0.05 \%$ Tween20 ) and $100 \mu$ l of DENV2 RVPs diluted 1:10 in blocking buffer was added to wells coated with 
murine mAb $4 \mathrm{G} 2$ and incubated for $1 \mathrm{hr}$ at RT and $37^{\circ} \mathrm{C}$. Plates were washed 6 times and incubated with $5 \mu \mathrm{g} /$ well of primary mAbs in $100 \mu$ l blocking buffer for $1 \mathrm{~h}$ at room temperature or $37^{\circ} \mathrm{C}$. Plates were washed 6 times and incubated with horseradish peroxidase (HRP)conjugated mouse anti-human IgG Fc secondary antibody (Cat\# 05-4220; ThermoFisher Scientific) diluted 1:1000 in $100 \mu \mathrm{l}$ blocking buffer for $1 \mathrm{~h}$ at room temperature or $37^{\circ} \mathrm{C}$. Plates were washed 6 times, and $100 \mu \mathrm{l}$ TMB substrate (Cat\# 34028; Thermo Fisher Scientific) was added at room temperature. The reaction was stopped after 6 min by adding $50 \mu \mathrm{l}$ of $1 \mathrm{~N} \mathrm{HCL}$. The absorbance at $450 \mathrm{~nm}$ was determined using a microplate reader (SpectraMax i3, Molecular Devices, San Jose, CA).

\section{Protein array printing and ELISA}

Spotted protein arrays $(5 \times 6)$ were printed onto each well of Greiner high-binding 96-well plates (Cat\# 655097, Thermo Fisher Scientific) using a sciFLeXARRAYER S12 (Scienion AG, Berlin). An array with $75 x$ final concentration of sucrose-purified DENV2 RVPs and a final concentration of $180 \mu \mathrm{g} / \mathrm{mL}$ of recombinant DENV2 $16681 \mathrm{E}$ protein was printed alongside $10 \mu \mathrm{g} / \mathrm{mL}$ antihuman IgG Fc (Cat\# 09-005-098; Jackson ImmunoResearch), and $1 \mu \mathrm{g} / \mathrm{mL}$ biotinylated kappa secondary (Cat\# 2060-08, SouthernBiotech, Birmingham, AL). Probes were diluted 1:1 with D12 buffer (Cat\# CBP-5436-25; Scienion AG) and printed at the final concentrations indicated above in triplicate spots from a 384-well source plate (Cat\# CPG-5502-1; Scienion AG) chilled to dew point with $3 \times 350 \mathrm{pL}$ drops per spot at $60 \%$ humidity on each 96 -well plate. Plates were cured overnight at $70 \%$ humidity before vacuum sealing.

For ELISAs, printed 96-well plates were washed once with binding buffer $(0.5 \% \mathrm{BSA}+0.025 \%$ Tween in PBS) then blocked in $100 \mu \mathrm{l} /$ well blocking buffer (3\% BSA in PBS $+0.05 \%$ Tween-20 (PBST)). After $1 \mathrm{~h}$, blocking buffer was removed and $100 \mu \mathrm{l} /$ well of test $\mathrm{mAbs}$ diluted in binding buffer added and incubated overnight at $4^{\circ} \mathrm{C}$. We tested twelve 3-fold serial dilutions of J9, J8, C4, EDE1 C10, EDE2 B7 and CR4354 starting at $200 \mu \mathrm{g} / \mathrm{mL}$; and B10, M1, L8 and 17 starting at $2 \mu \mathrm{g} / \mathrm{mL}$. The following day, plates were washed 3 times with PBST, and $100 \mu \mathrm{l} / \mathrm{well}$ of goat anti-human IgG Fc-BIOT (Cat\# 2014-08; Southern Biotech) secondary antibody diluted 1:10,000 in binding buffer was added. After $1 \mathrm{~h}$ shaking incubation at room temperature, plates were washed 3 times, followed by $1 \mathrm{~h}$ shaking incubation at room temperature with $100 \mu \mathrm{l} /$ well Pierce High Sensitivity Streptavidin-HRP (Cat\# 21130, Thermo Fisher Scientific). Plates were again washed 3 times, developed for 20 min with $50 \mu \mathrm{l} /$ well SciColor T12 (Cat\# CD-5600-100; Scienion AG), then analyzed using sciREADER CL2 (Scienion AG). Dose-response binding curves were analyzed by non-linear regression with a variable slope (GraphPadPrism v8, GraphPad Software Inc., San Diego, CA).

\section{Neutralization and antibody-dependent enhancement assays}

RVP stocks diluted to 5-10\% final infectivity were incubated with 5-fold dilutions of mAb or heatinactivated $\left(65^{\circ} \mathrm{C}\right.$ for $\left.30 \mathrm{~min}\right)$ serum for $1 \mathrm{~h}$ at room temperature before addition of RajiDCSIGNR cells (neutralization assays) or K562 cells (ADE assays). After $48 \mathrm{~h}$ incubation at $37^{\circ} \mathrm{C}$, cells were fixed in $2 \%$ paraformaldehyde and GFP positive cells were quantified by flow cytometry (Intellicyt iQue Screener Plus, Sartorius AG). Dose-response neutralization curves were analyzed by non-linear regression with a variable slope (GraphPadPrism v8, GraphPad 
Software Inc.). Fab fragments were generated and purified from IgGs using the Pierce Fab Preparation Kit (Cat\# PI44985; Thermo Scientific) and used in neutralization assays at 2x molar concentration relative to $\lg$.

Pre- and post-attachment neutralization assays were carried out as previously described (Xu et al., 2017) using Raji-DCSIGNR cells, DENV2 RVPs, and serial 5-fold dilutions of mAb starting at $150 \mu \mathrm{g} / \mathrm{mL}$ (J9 and J8) or $300 \mu \mathrm{g} / \mathrm{mL}$ (C4 and EDE1 C10). All cells, RVPs, mAbs, and media were pre-chilled to $4^{\circ} \mathrm{C}$ prior to use. For the pre-attachment assay, mAb dilutions were mixed with undiluted DENV2 RVPs for $1 \mathrm{~h}$ at $4^{\circ} \mathrm{C}$ followed by the addition of Raji-DCSIGNR cells and incubation for $1 \mathrm{~h}$ at $4^{\circ} \mathrm{C}$. Cells were washed 3 times with media, resuspended in media and incubated for $48 \mathrm{~h}$ at $37^{\circ} \mathrm{C}$. For the post-attachment assay, undiluted DENV2 RVPs were incubated with Raji-DCSIGNR cells for $1 \mathrm{~h}$ at $4^{\circ} \mathrm{C}$, washed three times with media, resuspended in fresh media and incubated with antibody dilutions. After $1 \mathrm{~h}$ at $4^{\circ} \mathrm{C}$, cells were washed three times with media, resuspended in media and incubated for $48 \mathrm{~h}$ at $37^{\circ} \mathrm{C}$. After $48 \mathrm{~h}$ at $37^{\circ} \mathrm{C}$, cells from both pre- and post-attachment assays were fixed in $2 \%$ paraformaldehyde. GFP positive cells were quantified by flow cytometry after $48 \mathrm{~h}$ incubation, as described above.

\section{Preparation of PBMCs for BCR repertoire analysis}

A $1 \mathrm{ml}$ vial of PBMCs was thawed rapidly in a $37^{\circ} \mathrm{C}$ water bath, immediately diluted into $9 \mathrm{ml}$ of B cell growth media containing Corning® DMEM [+] $4.5 \mathrm{~g} / \mathrm{L}$ glucose, sodium pyruvate [-] Lglutamine (VWR International, Radnor, PA), 1x Pen/Strep/Glu and 10\% ultralow IgG HI-FBS (Thermo Fisher Scientific), and pelleted at $350 \mathrm{xg}$ for $5 \mathrm{~min}$. The cells were resuspended in 1 $\mathrm{mL}$ of growth media and filtered through a $5 \mathrm{ml}$ polystyrene tube with a cell strainer cap (Thomas Scientific, Swedesboro, NJ). One half of the PBMCs were transferred to the T25 flask with feeder cells and B cell stimulation media as described previously (Waltari et al., 2019) and the other half was spun down in a $1.5 \mathrm{ml}$ Eppendorf tube at $8000 \mathrm{rpm}$ for $5 \mathrm{~min}$, resuspended in $600 \mu \mathrm{l} \mathrm{RLT}$ (Qiagen, Hilden, Germany) + beta-mercaptoethanol, allowed to lyse for 5 min, snap frozen on dry ice and stored at $-80^{\circ} \mathrm{C}$ until RNA purification with the Qiagen AllPrep RNA/DNA kit (Qiagen). Immunoglobulin amplicon preparation, sequencing and BCR analysis were previously described (Waltari et al., 2019). Lineage trees were constructed using the IgPhyML package in the Immcantation pipeline (Hoehn, Fowler, Lunter, \& Pybus, 2016) to construct a somatic hypermutation-optimized maximum likelihood phylogeny of the heavy chain sequences clonally related to $\mathrm{J} 9$ and $\mathrm{J} 8$. 


\section{Figure legends}

Figure 1. Binding profile of mAbs. A single dilution of the mAbs indicated on the $x$-axis was tested for binding to DENV2 (A) soluble recombinant $E$ protein $(r E)$ and $(B)$ reporter virus particles (RVPs) at room temperature (RT) and $37^{\circ} \mathrm{C}$ by ELISA. The y-axis shows absorbance values at $450 \mathrm{~nm}$. Error bars indicate the range of values obtained in duplicate wells. Data are representative of 3 independent experiments. The dotted horizontal line in $(B)$ indicates the average A450 values obtained for negative control WNV-specific mAb CR4354. Representative dose-response binding curves of the indicated mAbs to DENV2 (C) rE and (D) RVPs at room temperature. The $y$-axis shows binding signal intensity in arbitrary units (AU). Error bars indicate the standard deviation (SD) of triplicate spots within one well of the microarray. Binding curves are representative of two independent experiments.

Figure 2. Neutralization profile of mAbs. (A) Representative mAb dose-response neutralization curves against DENV1-4, ZIKV, and WNV RVPs. Infectivity levels were normalized to those observed in the absence of antibody. Data points and error bars indicate the mean and range, respectively. Results are representative of at least 3 independent experiments, each performed in duplicate. (B) MAb concentrations resulting in $50 \%$ inhibition of infectivity $\left(\mathrm{IC}_{50}\right)$ from dose-response neutralization experiments described in $(A)$. Values represent the mean of at least 3 independent experiments, each performed in duplicate. The heatmap indicates neutralization potency, as defined in the key. Grey boxes indicate that $50 \%$ neutralization was not achieved at the highest mAb concentration tested $(10 \mu \mathrm{g} / \mathrm{ml})$. The patient $(\mathrm{Pt})$ from which mAbs were isolated are indicated above each mAb name. MAbs from shared clonal families are indicated.

Figure 3. Mechanism of neutralization. Representative dose-response curves for pre- and post-attachment neutralization of DENV2 16681 RVPs by the indicated mAbs. Results are representative of at least 2 independent experiments each performed in duplicate. Data points and error bars indicate the mean and range, respectively.

Figure 4. Critical $E$ protein residues for $\mathrm{mAb}$ binding. Individual alanine mutation of a subset of DENV2 E residues decreased binding by mAbs (A) M1 and L8, (B) 17 or (C) J9 as shown, but did not affect binding by other mAbs, including EDE1 C10 and a previously screened control $\mathrm{mAb}(\mathrm{FL})$ targeting the fusion loop (unpublished). Error bars represent the mean and range (half of the maximum-minus-minimum values) of at least two biological replicates. The dotted horizontal line indicates $80 \%$ reduction in $\mathrm{mAb}$ binding reactivity to mutant compared to wildtype DENV2 E. Above each graph, residues involved in binding of the corresponding $\mathrm{mAb}$ are highlighted on the ribbon structure of one of the monomers (black) within the DENV2 E dimer (PDB: 1OAN). Residues in DI, DII, DIII, and DII fusion loop are indicated in red, yellow, blue, and green, respectively.

Figure 5. Critical E protein residues for $\mathrm{mAb}$ neutralization. (A) Ribbon structure of the DENV2 E dimer (PDB: 1OAN) with one monomer in black and the other in grey. The conserved DIl fusion loop is shown in green. Colored spheres indicate residues that contribute to J9 recognition identified in Figure S8A and summarized in (B). Bar graphs depict the mean fold change in $\mathrm{IC}_{50}$ values against the DENV2 $\mathrm{E}$ variants indicated on the $\mathrm{x}$-axis relative to DENV2 wildtype RVPs for mAbs (B) J9, (C) J8, (D) C4, (E) EDE1 C10, and (F) EDE2 B7. For each $\mathrm{mAb}$, wildtype ZIKV RVPs were included as controls. Mean values were obtained from 2 to 7 independent experiments represented by data points. Error bars indicate the standard deviation ( $n>2$ experiments) or range ( $n=2$ experiments). Bar colors correspond to those of spheres in 
(A) to indicate location within the $\mathrm{E}$ dimer. The dotted horizontal line indicates a 4-fold increase in $\mathrm{IC}_{50}$ value relative to wildtype DENV2.

Figure 6. Lineage analysis of the J9/J8 clonal family. (A) Maximum likelihood phylogeny of $\mathrm{mAbs}$ related to $\mathrm{J} 9$ and $\mathrm{J} 8$ found in the BCR repertoire of patient 013 created using the HLP19 model in IgPhyML. VH germline sequence (IGHV1-69*05 + IGHD2-2 + IGHJ5) is shown at the top. Red letters and tips indicate sequences found in unstimulated PBMCs, black letters and tips indicate sequences found in stimulated PBMCs, and magenta letters indicate sequences found both in unstimulated and stimulated PBMCs. Letters correspond to sequences shown in the alignment in (B). Triangles next to tips indicate IgA sequences. (B) Heavy chain alignment of selected mAbs within the J9/J8 lineage found in the BCR repertoire of patient 013 . Letters correspond to sequences shown in (A), with isotype indicated. The germline sequence (IGHV1$69+$ IGHD2-2 + IGHJ5) is shown first, followed by a constructed sequence with 5 amino acid changes shown as "GERM 5mut." Kabat numbering is shown on top. Amino acid changes are highlighted in gray, and boxes indicate the CDR regions. (C) Light chain alignment of J8 and J9. The germline sequence (IGKV3-11 + IGKJ2) is shown first, with Kabat numbering shown on top. Amino acid changes are highlighted in gray, and boxes indicate the CDR regions.

Figure 7. Contribution of VH and VL SHM to J9 and J8 neutralizing activity. Summary of $\mathrm{IC}_{50}$ values of $\mathrm{J9}$ and J8 IgG variants against (A) DENV1, (B) DENV2, (C) DENV3, and (D) DENV4 RVPs. Bars represent mean IC 50 values obtained from 3 to 4 independent experiments indicated by data points for each mAb. Error bars show the SD. Values at the dotted horizontal line indicates that $50 \%$ neutralization was not achieved at the highest IgG concentration tested $(10 \mu \mathrm{g} / \mathrm{ml}) .1 C_{50}$ values for fully mature $\mathrm{J} 9$ and $\mathrm{J} 8$ are shown in red and blue bars, respectively. J8J9_full germ: germline J8/J9 heavy chain (HC) paired with J8/J9 light chain (LC); J9_HCgerm: J9 germline HC paired with J9 mature LC; J9LC_germ: J9 mature HC paired with J9 germline LC; J8_HCgerm: J8 germline HC paired with J8 mature LC; J8_LCgerm: J8 mature HC paired with $\mathrm{J9}$ germline LC; J9_HC5mut: J9 HC with 5 mutations indicated in Figure 6B paired with $\mathrm{J} 9$ mature LC; J8_HC5mut: J8 HC with 5 mutations indicated in Figure 6B paired with J8 mature LC; J9HC_J8LC: J9 mature HC paired with J8 mature LC; J8HC_J9LC: J8 mature HC paired with $\mathrm{J} 9$ mature LC; J9 -G: J9 HC with a single glycine deletion in FR2 paired with mature J9 LC. 


\section{Supplemental Information}

Table S1. Percent mAb binding reactivity to DENV2 E protein alanine scanning mutagenesis library normalized to wildtype DENV2

Table S2. Summary of Ig sequences, clonal families, and mean SHM in unstimulated versus stimulated PBMCs from patient 013.

Table S3. Sequences from patient 013 unstimulated and stimulated PBMCs related to clonal families of single plasmablasts with reactivity to DENV

Figure S1. Characteristics of plasmablast-derived mAbs from DENV-infected patients. MAb sequences were identified from single plasmablasts of DENV-infected patient 013 and patient 020, as previously described (Zanini et al., 2018). The patient from which corresponding $\mathrm{mAb}$ sequences were identified is listed in the first column, followed by mAb clonal family ID, mAb name, and gene usage, \% nucleotide (nt) SHM, and CDR3 amino acid (aa) length for the variable heavy $(\mathrm{VH})$ and light $(\mathrm{VL})$ chain genes. $\mathrm{VH}$ and $\mathrm{VL}$ sequences were cloned into IgG1 expression vectors and transfected into mammalian cells. Neat crude lgG1-containing culture supernatant was tested for binding to recombinant DENV2 E protein ectodomain and DENV2 RVPs by ELISA, and for neutralizing activity against the indicated RVPs. MAbs $3 \mathrm{H} 5-1$ (2 $\mu \mathrm{g} / \mathrm{mL})$, EDE2 B7 $(2 \mu \mathrm{g} / \mathrm{mL})$ and EDE1 C10 $(10 \mu \mathrm{g} / \mathrm{mL})$, and CR4354 $(2 \mu \mathrm{g} / \mathrm{mL})$ were used as controls. MAb binding activity is expressed as fold-change in absorbance values over negative control wells containing media only. The heatmap (light to dark blue) indicates strength of binding, as defined in the key below the table. A value of 1 indicates no increase in binding relative to negative control wells. Percent neutralization was calculated using the formula: (\% infection in the absence of lgG1 - \% infection in the presence of IgG1) / (\% infection in the absence of $\lg \mathrm{G} 1$ ) $\times 100$. The heatmap (yellow to red) indicates the range of neutralization potencies as indicated in the key below the table. Results are representative of 2 independent experiments. Under the crude IgG column, a value of $<0.0005$ indicates undetectable levels of IgG1 in crude culture supernatant. Antibodies selected for further characterization are shown in bold. "N/a," not applicable; "nc," not successfully cloned; "nd," not determined.

Figure S2. Neutralization potency of IgG and Fab fragments. (A) J9, (B) J8, (C) C4, and (D) EDE1 C10 were tested as Fab fragments or full-length IgG for neutralization of DENV2 RVPs. Dose-response neutralization curves represent 3 independent experiments, each performed in duplicate. Data points and error bars indicate the mean and range, respectively. (E) Mean IC 50 values of the indicated IgG or Fab fragment from 3 independent experiments represented by data points. Error bars represent the SD. Values at the dotted horizontal line indicates that $50 \%$ neutralization was not achieved at the highest concentration of IgG or Fab tested. Fabs were tested at $2 x$ excess molar concentration relative to lgG.

Figure S3. Neutralization potency of mAbs against contemporary DENV1-4 strains. Neutralization of contemporary DENV1-4 strains by (A) J9, C4, and (B) J8 was determined by intracellular staining with AF488-conjugated $4 \mathrm{G} 2$ at $48 \mathrm{~h}$ post-infection. Error bars indicate the range of duplicate infections. Infectivity levels were normalized to those in the absence of neutralizing antibody. Dose-response neutralization curves represent one experiment.

Figure S4. mAb neutralization of standard and mature RVP preparations. (A) Doseresponse neutralization curves for the indicated mAbs against DENV2 RVPs prepared under standard conditions (Std) or in the presence of overexpressed furin to generate mature RVPs (Furin). Data points and error bars indicate the mean and range of infectivity in duplicate wells, 
respectively. (B) Mean $I C_{50}$ values of $m A$ bs against standard or mature RVPs from 3 independent experiments depicted by data points. Error bars indicate the SD. P-values were obtained from two-tailed paired t-tests.

Figure S5. Antibody-dependent enhancement (ADE) of DENV2, ZIKV and WNV infection. Serial dilutions of the indicated mAbs were tested for ADE of (A) DENV2, (B) ZIKV or (C) WNV RVP infection of K562 cells. Error bars indicate the mean of infection in duplicate wells. Bar graphs represent average mAb concentrations at peak enhancement of (D) DENV2, (E) ZIKV or (F) WNV RVP infection obtained from 2-3 independent experiments, each represented by a data point. Where indicated, error bars represent the SD.

Figure S6. DENV2 E protein mutagenesis. (A) Alignment of DENV1-4, ZIKV, and WNV E ectodomain amino acid residues obtained using ClustalW2. Red, yellow, green, and blue bars above the alignment indicate residues within E protein DI, DII, DII-fusion loop, and DIII, respectively. Squares above colored bars indicate residues selected for mutagenesis and generation of RVP variants tested for sensitivity to J9 neutralization: gray squares $=$ no effect on neutralization sensitivity; black squares = reduced sensitivity to $\mathrm{J} 9$ neutralization. Yellow squares indicate residues conserved across flaviviruses and important for $\mathrm{mAb} 17$ binding. The sequence used for ZIKV H/PF/2013 differs at two amino acids (residue $246 \mathrm{~K}>\mathrm{R}$ and $345 \mathrm{M}>\mathrm{I}$ from GenBank accession number AHZ13508.1, as previously described (Dowd et al., 2016). (B) Ribbon structure of the DENV2 E dimer (PDB 1OAN) with 34 individually mutated residues shown as gray spheres. E protein domains are color-coded as in $(A)$. (C) Ribbon structure of the DENV2 E dimer (PDB 1OAN) with one monomer shown in black, and the other in gray. Colored spheres indicate the locations of paired mutations: K47T+V151T (red); L56V+Q211E (orange); E85Q+Q86S (green); H149S+V151T (blue); Y178F+M287V (cyan); N194S+E195D (purple); Q316L+K394S (yellow).

Figure S7. Infectious titer of DENV2 RVPs encoding E protein mutations. Infectious titers of DENV2 RVP encoding (A) single or (B) double E protein mutations. For each graph, white bars show the infectious titer of WT DENV2 RVP, and red, yellow, and blue bars represent mutations in DI, DII, and DIII, respectively. In (B), the purple bar represents a paired mutation at one residue in DI (Y178F) and another in DIII (M297V). Titers are based on one or two independent RVP preparations, as indicated by data points. Where present, error bars represent the range of infectivity from 2 independent RVP preparations.

Figure S8. Effect of E protein mutations mAb neutralization potency. We screened a panel of DENV2 RVP variants encoding single (left) or double (right) E protein mutations for sensitivity to neutralization by mAbs (A) J9, (B) J8, (C) C4, (D) EDE1 C10, and (E) EDE2 B7. Bar graphs represent average fold-change in $\mathrm{IC}_{50}$ relative to WT DENV2 RVP obtained from at least 2 independent experiments, as indicated by data points. Error bars indicate the range $(n=2)$ or SD $(n>2)$. The dotted line represents a 4 -fold increase in $I C_{50}$ relative to DENV2 WT. On the left panel, red, yellow, and blue bars indicate mutations are residues in DI, DII, and DIII, respectively. For each mAb, neutralization of WT ZIKV RVPs is included as a control.

Figure S9. Effect of E protein mutations on patient 013 serum neutralization potency. Neutralizing activity of mAb J9 and longitudinal serum samples from patient 013 were tested against DENV2 RVP variants encoding $E$ protein mutations that reduced J9 neutralization potency. ZIKV WT RVP was included as a control. Serum samples 013-1, 013-2 and 013-3 were collected 4, 8 and 22 days after onset of fever, respectively. Dose-response neutralization curves are representative of 3 independent experiments, each performed in duplicate. Error bars indicate the range of infectivity normalized to infection levels in the absence of antibody. 
Figure S10. Patient 013 VH gene usage. Germline VH gene usage among the unstimulated (circles) and stimulated (triangles) PBMC repertoires of patient 013, with only IgM (top) and IgG (bottom) sequences shown. Genes are grouped by color into gene families, as indicated in the key.

Figure S11. Analytical size exclusion chromatography of recombinant IgGs. Biophysical characterization of $\mathrm{J} 9$ and $\mathrm{J} 8 \mathrm{IgG}$ variants by analytical size exclusion chromatography (Superdex S200 Increase 3.2/300). A single major peak at $280 \mathrm{~nm}$ corresponding to monomeric $\lg \mathrm{G}$ is observed. 


\section{References}

Ansarah-Sobrinho, C., Nelson, S., Jost, C. A., Whitehead, S. S., \& Pierson, T. C. (2008). Temperature-dependent production of pseudoinfectious dengue reporter virus particles by complementation. Virology, 381(1), 67-74. doi:10.1016/j.virol.2008.08.021

Appanna, R., Kg, S., Xu, M. H., Toh, Y. X., Velumani, S., Carbajo, D., . . Fink, K. (2016). Plasmablasts During Acute Dengue Infection Represent a Small Subset of a Broader Virus-specific Memory B Cell Pool. EBioMedicine, 12, 178-188. doi:10.1016/j.ebiom.2016.09.003

Barba-Spaeth, G., Dejnirattisai, W., Rouvinski, A., Vaney, M. C., Medits, I., Sharma, A., . . Rey, F. A. (2016). Structural basis of potent Zika-dengue virus antibody cross-neutralization. Nature, 536(7614), 48-53. doi:10.1038/nature18938

Bell, S. M., Katzelnick, L., \& Bedford, T. (2019). Dengue genetic divergence generates withinserotype antigenic variation, but serotypes dominate evolutionary dynamics. Elife, 8. doi:10.7554/eLife.42496

Bhatt, S., Gething, P. W., Brady, O. J., Messina, J. P., Farlow, A. W., Moyes, C. L., . . Hay, S. I. (2013). The global distribution and burden of dengue. Nature, 496(7446), 504-507. doi:10.1038/nature12060

Boonyaratanakornkit, J., \& Taylor, J. J. (2019). Techniques to Study Antigen-Specific B Cell Responses. Front Immunol, 10, 1694. doi:10.3389/fimmu.2019.01694

Chen, F., Tzarum, N., Wilson, I. A., \& Law, M. (2019). VH1-69 antiviral broadly neutralizing antibodies: genetics, structures, and relevance to rational vaccine design. Curr Opin Virol, 34, 149-159. doi:10.1016/j.coviro.2019.02.004

Cherrier, M. V., Kaufmann, B., Nybakken, G. E., Lok, S. M., Warren, J. T., Chen, B. R., . . . Fremont, D. H. (2009). Structural basis for the preferential recognition of immature flaviviruses by a fusion-loop antibody. EMBO J, 28(20), 3269-3276. doi:10.1038/emboj.2009.245

Cortez, V., Odem-Davis, K., McClelland, R. S., Jaoko, W., \& Overbaugh, J. (2012). HIV-1 superinfection in women broadens and strengthens the neutralizing antibody response. PLoS Pathog, 8(3), e1002611. doi:10.1371/journal.ppat.1002611

Corti, D., \& Lanzavecchia, A. (2014). Efficient Methods To Isolate Human Monoclonal Antibodies from Memory B Cells and Plasma Cells. Microbiol Spectr, 2(5). doi:10.1128/microbiolspec.AID-0018-2014

Crank, M. C., Ruckwardt, T. J., Chen, M., Morabito, K. M., Phung, E., Costner, P. J., . . Team, V. R. C. S. (2019). A proof of concept for structure-based vaccine design targeting RSV in humans. Science, 365(6452), 505-509. doi:10.1126/science.aav9033

Davidson, E., \& Doranz, B. J. (2014). A high-throughput shotgun mutagenesis approach to mapping B-cell antibody epitopes. Immunology, 143(1), 13-20. doi:10.1111/imm.12323

Davis, C. W., Jackson, K. J. L., McElroy, A. K., Halfmann, P., Huang, J., Chennareddy, C., . . . Ahmed, R. (2019). Longitudinal Analysis of the Human B Cell Response to Ebola Virus Infection. Cell, 177(6), 1566-1582 e1517. doi:10.1016/j.cell.2019.04.036

Davis, C. W., Nguyen, H. Y., Hanna, S. L., Sanchez, M. D., Doms, R. W., \& Pierson, T. C. (2006). West Nile virus discriminates between DC-SIGN and DC-SIGNR for cellular attachment and infection. J Virol, 80(3), 1290-1301. doi:10.1128/JVI.80.3.12901301.2006

de Alwis, R., Smith, S. A., Olivarez, N. P., Messer, W. B., Huynh, J. P., Wahala, W. M., ... de Silva, A. M. (2012). Identification of human neutralizing antibodies that bind to complex epitopes on dengue virions. Proc Natl Acad Sci U S A, 109(19), 7439-7444. doi:10.1073/pnas.1200566109

Dejnirattisai, W., Wongwiwat, W., Supasa, S., Zhang, X., Dai, X., Rouvinski, A., . . Screaton, G. R. (2015). A new class of highly potent, broadly neutralizing antibodies isolated from 
viremic patients infected with dengue virus. Nat Immunol, 16(2), 170-177. doi:10.1038/ni.3058

Deng, Y. Q., Dai, J. X., Ji, G. H., Jiang, T., Wang, H. J., Yang, H. O., . . Qin, C. F. (2011). A broadly flavivirus cross-neutralizing monoclonal antibody that recognizes a novel epitope within the fusion loop of E protein. PLoS One, 6(1), e16059. doi:10.1371/journal.pone.0016059

Doria-Rose, N. A., Louder, M. K., Yang, Z., O'Dell, S., Nason, M., Schmidt, S. D., . . Mascola, J. R. (2012). HIV-1 neutralization coverage is improved by combining monoclonal antibodies that target independent epitopes. J Virol, 86(6), 3393-3397. doi:10.1128/JVI.06745-11

Dowd, K. A., DeMaso, C. R., Pelc, R. S., Speer, S. D., Smith, A. R. Y., Goo, L., . . Pierson, T. C. (2016). Broadly Neutralizing Activity of Zika Virus-Immune Sera Identifies a Single Viral Serotype. Cell Rep, 16(6), 1485-1491. doi:10.1016/j.celrep.2016.07.049

Dowd, K. A., Jost, C. A., Durbin, A. P., Whitehead, S. S., \& Pierson, T. C. (2011). A dynamic landscape for antibody binding modulates antibody-mediated neutralization of West Nile virus. PLoS Pathog, 7(6), e1002111. doi:10.1371/journal.ppat.1002111

Fibriansah, G., Tan, J. L., Smith, S. A., de Alwis, A. R., Ng, T. S., Kostyuchenko, V. A., . . Lok, S. M. (2014). A potent anti-dengue human antibody preferentially recognizes the conformation of $E$ protein monomers assembled on the virus surface. EMBO Mol Med, 6(3), 358-371. doi:10.1002/emmm.201303404

Goo, L., Debbink, K., Kose, N., Sapparapu, G., Doyle, M. P., Wessel, A. W., . . Pierson, T. C. (2019). A protective human monoclonal antibody targeting the West Nile virus $E$ protein preferentially recognizes mature virions. Nat Microbiol, 4(1), 71-77. doi:10.1038/s41564018-0283-7

Goo, L., Jalalian-Lechak, Z., Richardson, B. A., \& Overbaugh, J. (2012). A combination of broadly neutralizing HIV-1 monoclonal antibodies targeting distinct epitopes effectively neutralizes variants found in early infection. J Virol, 86(19), 10857-10861. doi:10.1128/JVI.01414-12

Goo, L., VanBlargan, L. A., Dowd, K. A., Diamond, M. S., \& Pierson, T. C. (2017). A single mutation in the envelope protein modulates flavivirus antigenicity, stability, and pathogenesis. PLoS Pathog, 13(2), e1006178. doi:10.1371/journal.ppat.1006178

Graham, B. S., Gilman, M. S. A., \& McLellan, J. S. (2019). Structure-Based Vaccine Antigen Design. Annu Rev Med, 70, 91-104. doi:10.1146/annurev-med-121217-094234

Guzman, M. G., \& Harris, E. (2015). Dengue. Lancet, 385(9966), 453-465. doi:10.1016/S01406736(14)60572-9

Hadinegoro, S. R., Arredondo-Garcia, J. L., Capeding, M. R., Deseda, C., Chotpitayasunondh, T., Dietze, R., . . Group, C.-T. D. V. W. (2015). Efficacy and Long-Term Safety of a Dengue Vaccine in Regions of Endemic Disease. N Engl J Med, 373(13), 1195-1206. doi:10.1056/NEJMoa1506223

Halstead, S. B. (2014). Dengue Antibody-Dependent Enhancement: Knowns and Unknowns. Microbiol Spectr, 2(6). doi:10.1128/microbiolspec.AID-0022-2014

Hasan, S. S., Miller, A., Sapparapu, G., Fernandez, E., Klose, T., Long, F., . . Rossmann, M. G. (2017). A human antibody against Zika virus crosslinks the $E$ protein to prevent infection. Nat Commun, 8, 14722. doi:10.1038/ncomms14722

Hoehn, K. B., Fowler, A., Lunter, G., \& Pybus, O. G. (2016). The Diversity and Molecular Evolution of B-Cell Receptors during Infection. Mol Biol Evol, 33(5), 1147-1157. doi:10.1093/molbev/msw015

Hu, D., Zhu, Z., Li, S., Deng, Y., Wu, Y., Zhang, N., . . Ying, T. (2019). A broadly neutralizing germline-like human monoclonal antibody against dengue virus envelope domain III. PLoS Pathog, 15(6), e1007836. doi:10.1371/journal.ppat.1007836 
Juraska, M., Magaret, C. A., Shao, J., Carpp, L. N., Fiore-Gartland, A. J., Benkeser, D., . . . Gilbert, P. B. (2018). Viral genetic diversity and protective efficacy of a tetravalent dengue vaccine in two phase 3 trials. Proc Natl Acad Sci U S A, 115(36), E8378-E8387. doi:10.1073/pnas.1714250115

Katzelnick, L. C., Fonville, J. M., Gromowski, G. D., Bustos Arriaga, J., Green, A., James, S. L., . . . Smith, D. J. (2015). Dengue viruses cluster antigenically but not as discrete serotypes. Science, 349(6254), 1338-1343. doi:10.1126/science.aac5017

Katzelnick, L. C., Gresh, L., Halloran, M. E., Mercado, J. C., Kuan, G., Gordon, A., . . . Harris, E. (2017). Antibody-dependent enhancement of severe dengue disease in humans. Science, 358(6365), 929-932. doi:10.1126/science.aan6836

Kaufmann, B., Vogt, M. R., Goudsmit, J., Holdaway, H. A., Aksyuk, A. A., Chipman, P. R., . . Rossmann, M. G. (2010). Neutralization of West Nile virus by cross-linking of its surface proteins with Fab fragments of the human monoclonal antibody CR4354. Proc Natl Acad Sci U S A, 107(44), 18950-18955. doi:10.1073/pnas.1011036107

Keeffe, J. R., Van Rompay, K. K. A., Olsen, P. C., Wang, Q., Gazumyan, A., Azzopardi, S. A., . . . Robbiani, D. F. (2018). A Combination of Two Human Monoclonal Antibodies Prevents Zika Virus Escape Mutations in Non-human Primates. Cell Rep, 25(6), 1385-1394 e1387. doi:10.1016/j.celrep.2018.10.031

Khursheed, M., Khan, U. R., Ejaz, K., Fayyaz, J., Qamar, I., \& Razzak, J. A. (2013). A comparison of WHO guidelines issued in 1997 and 2009 for dengue fever - single centre experience. J Pak Med Assoc, 63(6), 670-674. Retrieved from https://www.ncbi.nlm.nih.gov/pubmed/23901662

Kong, R., Louder, M. K., Wagh, K., Bailer, R. T., deCamp, A., Greene, K., . . Mascola, J. R. (2015). Improving neutralization potency and breadth by combining broadly reactive HIV1 antibodies targeting major neutralization epitopes. J Virol, 89(5), 2659-2671. doi:10.1128/JVI.03136-14

Kostyuchenko, V. A., Lim, E. X., Zhang, S., Fibriansah, G., Ng, T. S., Ooi, J. S., . . Lok, S. M. (2016). Structure of the thermally stable Zika virus. Nature, 533(7603), 425-428. doi:10.1038/nature17994

Kraemer, M. U. G., Reiner, R. C., Jr., Brady, O. J., Messina, J. P., Gilbert, M., Pigott, D. M., . . . Golding, N. (2019). Past and future spread of the arbovirus vectors Aedes aegypti and Aedes albopictus. Nat Microbiol, 4(5), 854-863. doi:10.1038/s41564-019-0376-y

Kuhn, R. J., Zhang, W., Rossmann, M. G., Pletnev, S. V., Corver, J., Lenches, E., . . Strauss, J. H. (2002). Structure of dengue virus: implications for flavivirus organization, maturation, and fusion. Cell, 108(5), 717-725. doi:10.1016/s0092-8674(02)00660-8

Kwong, P. D., \& Mascola, J. R. (2018). HIV-1 Vaccines Based on Antibody Identification, B Cell Ontogeny, and Epitope Structure. Immunity, 48(5), 855-871. doi:10.1016/j.immuni.2018.04.029

Li, L., Meng, W., Horton, M., DiStefano, D. R., Thoryk, E. A., Pfaff, J. M., . . Zhang, N. (2019). Potent neutralizing antibodies elicited by dengue vaccine in rhesus macaque target diverse epitopes. PLoS Pathog, 15(6), e1007716. doi:10.1371/journal.ppat.1007716

Lim, X. N., Shan, C., Marzinek, J. K., Dong, H., Ng, T. S., Ooi, J. S. G., . . Lok, S. M. (2019). Molecular basis of dengue virus serotype 2 morphological switch from 29 degrees $C$ to 37 degrees C. PLoS Pathog, 15(9), e1007996. doi:10.1371/journal.ppat.1007996

Lingwood, D., McTamney, P. M., Yassine, H. M., Whittle, J. R., Guo, X., Boyington, J. C., .. . Nabel, G. J. (2012). Structural and genetic basis for development of broadly neutralizing influenza antibodies. Nature, 489(7417), 566-570. doi:10.1038/nature11371

Littaua, R., Kurane, I., \& Ennis, F. A. (1990). Human IgG Fc receptor II mediates antibodydependent enhancement of dengue virus infection. $J$ Immunol, 144(8), 3183-3186. Retrieved from https://www.ncbi.nlm.nih.gov/pubmed/2139079 
Lok, S. M., Kostyuchenko, V., Nybakken, G. E., Holdaway, H. A., Battisti, A. J., Sukupolvi-Petty, S., ... Rossmann, M. G. (2008). Binding of a neutralizing antibody to dengue virus alters the arrangement of surface glycoproteins. Nat Struct Mol Biol, 15(3), 312-317. doi:10.1038/nsmb.1382

MacLeod, D. T., Choi, N. M., Briney, B., Garces, F., Ver, L. S., Landais, E., . . Poignard, P. (2016). Early Antibody Lineage Diversification and Independent Limb Maturation Lead to Broad HIV-1 Neutralization Targeting the Env High-Mannose Patch. Immunity, 44(5), 1215-1226. doi:10.1016/j.immuni.2016.04.016

Messina, J. P., Brady, O. J., Golding, N., Kraemer, M. U. G., Wint, G. R. W., Ray, S. E., . . Hay, S. I. (2019). The current and future global distribution and population at risk of dengue. Nat Microbiol, 4(9), 1508-1515. doi:10.1038/s41564-019-0476-8

Messina, J. P., Brady, O. J., Scott, T. W., Zou, C., Pigott, D. M., Duda, K. A., . . Hay, S. I. (2014). Global spread of dengue virus types: mapping the 70 year history. Trends Microbiol, 22(3), 138-146. doi:10.1016/j.tim.2013.12.011

Mukhopadhyay, S., Kim, B. S., Chipman, P. R., Rossmann, M. G., \& Kuhn, R. J. (2003). Structure of West Nile virus. Science, 302(5643), 248. doi:10.1126/science.1089316

Nelson, S., Jost, C. A., Xu, Q., Ess, J., Martin, J. E., Oliphant, T., . . Pierson, T. C. (2008). Maturation of West Nile virus modulates sensitivity to antibody-mediated neutralization. PLoS Pathog, 4(5), e1000060. doi:10.1371/journal.ppat.1000060

Nybakken, G. E., Oliphant, T., Johnson, S., Burke, S., Diamond, M. S., \& Fremont, D. H. (2005). Structural basis of West Nile virus neutralization by a therapeutic antibody. Nature, 437(7059), 764-769. doi:10.1038/nature03956

Oliphant, T., Nybakken, G. E., Engle, M., Xu, Q., Nelson, C. A., Sukupolvi-Petty, S., . . . Diamond, M. S. (2006). Antibody recognition and neutralization determinants on domains I and II of West Nile Virus envelope protein. J Virol, 80(24), 12149-12159. doi:10.1128/JVI.01732-06

Paes, C., Ingalls, J., Kampani, K., Sulli, C., Kakkar, E., Murray, M., . . Doranz, B. J. (2009). Atomic-level mapping of antibody epitopes on a GPCR. J Am Chem Soc, 131(20), 69526954. doi:10.1021/ja900186n

Parameswaran, P., Liu, Y., Roskin, K. M., Jackson, K. K., Dixit, V. P., Lee, J. Y., . . Fire, A. Z. (2013). Convergent antibody signatures in human dengue. Cell Host Microbe, 13(6), 691-700. doi:10.1016/j.chom.2013.05.008

Patel, B., Longo, P., Miley, M. J., Montoya, M., Harris, E., \& de Silva, A. M. (2017). Dissecting the human serum antibody response to secondary dengue virus infections. PLoS Negl Trop Dis, 11(5), e0005554. doi:10.1371/journal.pntd.0005554

Pierson, T. C., \& Diamond, M. S. (2012). Degrees of maturity: the complex structure and biology of flaviviruses. Curr Opin Virol, 2(2), 168-175. doi:10.1016/j.coviro.2012.02.011

Pierson, T. C., Sanchez, M. D., Puffer, B. A., Ahmed, A. A., Geiss, B. J., Valentine, L. E., . . . Doms, R. W. (2006). A rapid and quantitative assay for measuring antibody-mediated neutralization of West Nile virus infection. Virology, 346(1), 53-65. doi:10.1016/j.virol.2005.10.030

Pierson, T. C., Xu, Q., Nelson, S., Oliphant, T., Nybakken, G. E., Fremont, D. H., \& Diamond, M. S. (2007). The stoichiometry of antibody-mediated neutralization and enhancement of West Nile virus infection. Cell Host Microbe, 1(2), 135-145. doi:10.1016/j.chom.2007.03.002

Prasad, V. M., Miller, A. S., Klose, T., Sirohi, D., Buda, G., Jiang, W., . . Rossmann, M. G. (2017). Structure of the immature Zika virus at 9 A resolution. Nat Struct Mol Biol, 24(2), 184-186. doi:10.1038/nsmb.3352

Priyamvada, L., Cho, A., Onlamoon, N., Zheng, N. Y., Huang, M., Kovalenkov, Y., ... Wrammert, J. (2016). B Cell Responses during Secondary Dengue Virus Infection Are 
Dominated by Highly Cross-Reactive, Memory-Derived Plasmablasts. J Virol, 90(12), 5574-5585. doi:10.1128/JVI.03203-15

Raut, R., Corbett, K. S., Tennekoon, R. N., Premawansa, S., Wijewickrama, A., Premawansa, G., . . de Silva, A. M. (2019). Dengue type 1 viruses circulating in humans are highly infectious and poorly neutralized by human antibodies. Proc Natl Acad Sci U S A, 116(1), 227-232. doi:10.1073/pnas.1812055115

Robbiani, D. F., Bozzacco, L., Keeffe, J. R., Khouri, R., Olsen, P. C., Gazumyan, A., . . . Nussenzweig, M. C. (2017). Recurrent Potent Human Neutralizing Antibodies to Zika Virus in Brazil and Mexico. Cell, 169(4), 597-609 e511. doi:10.1016/j.cell.2017.04.024

Rogers, T. F., Goodwin, E. C., Briney, B., Sok, D., Beutler, N., Strubel, A., . . Walker, L. M. (2017). Zika virus activates de novo and cross-reactive memory B cell responses in dengue-experienced donors. Sci Immunol, 2(14). doi:10.1126/sciimmunol.aan6809

Rouvinski, A., Guardado-Calvo, P., Barba-Spaeth, G., Duquerroy, S., Vaney, M. C., Kikuti, C. M., ... Rey, F. A. (2015). Recognition determinants of broadly neutralizing human antibodies against dengue viruses. Nature, 520(7545), 109-113. doi:10.1038/nature14130

Salje, H., Cummings, D. A. T., Rodriguez-Barraquer, I., Katzelnick, L. C., Lessler, J., Klungthong, C., . . Cauchemez, S. (2018). Reconstruction of antibody dynamics and infection histories to evaluate dengue risk. Nature, 557(7707), 719-723. doi:10.1038/s41586-018-0157-4

Sangkawibha, N., Rojanasuphot, S., Ahandrik, S., Viriyapongse, S., Jatanasen, S., Salitul, V., . . . Halstead, S. B. (1984). Risk factors in dengue shock syndrome: a prospective epidemiologic study in Rayong, Thailand. I. The 1980 outbreak. Am J Epidemiol, 120(5), 653-669. doi:10.1093/oxfordjournals.aje.a113932

Scheid, J. F., Mouquet, H., Feldhahn, N., Walker, B. D., Pereyra, F., Cutrell, E., . . . Nussenzweig, M. C. (2009). A method for identification of HIV gp140 binding memory B cells in human blood. J Immunol Methods, 343(2), 65-67. doi:10.1016/j.jim.2008.11.012

Scheid, J. F., Mouquet, H., Ueberheide, B., Diskin, R., Klein, F., Oliveira, T. Y., . . . Nussenzweig, M. C. (2011). Sequence and structural convergence of broad and potent HIV antibodies that mimic CD4 binding. Science, 333(6049), 1633-1637. doi:10.1126/science.1207227

Scherwitzl, I., Mongkolsapaja, J., \& Screaton, G. (2017). Recent advances in human flavivirus vaccines. Curr Opin Virol, 23, 95-101. doi:10.1016/j.coviro.2017.04.002

Shen, W. F., Galula, J. U., Liu, J. H., Liao, M. Y., Huang, C. H., Wang, Y. C., . . Chao, D. Y. (2018). Epitope resurfacing on dengue virus-like particle vaccine preparation to induce broad neutralizing antibody. Elife, 7. doi:10.7554/eLife.38970

Shi, X., Deng, Y., Wang, H., Ji, G., Tan, W., Jiang, T., . . Guo, Y. (2016). A bispecific antibody effectively neutralizes all four serotypes of dengue virus by simultaneous blocking virus attachment and fusion. MAbs, 8(3), 574-584. doi:10.1080/19420862.2016.1148850

Sirohi, D., Chen, Z., Sun, L., Klose, T., Pierson, T. C., Rossmann, M. G., \& Kuhn, R. J. (2016). The 3.8 A resolution cryo-EM structure of Zika virus. Science, 352(6284), 467-470. doi:10.1126/science.aaf5316

Smith, S. A., de Alwis, A. R., Kose, N., Harris, E., Ibarra, K. D., Kahle, K. M., . . Crowe, J. E., Jr. (2013). The potent and broadly neutralizing human dengue virus-specific monoclonal antibody $1 \mathrm{C} 19$ reveals a unique cross-reactive epitope on the bc loop of domain II of the envelope protein. MBio, 4(6), e00873-00813. doi:10.1128/mBio.00873-13

Stiasny, K., Kiermayr, S., Holzmann, H., \& Heinz, F. X. (2006). Cryptic properties of a cluster of dominant flavivirus cross-reactive antigenic sites. J Virol, 80(19), 9557-9568. doi:10.1128/JVI.00080-06

Sukupolvi-Petty, S., Austin, S. K., Engle, M., Brien, J. D., Dowd, K. A., Williams, K. L., . . . Diamond, M. S. (2010). Structure and function analysis of therapeutic monoclonal 
antibodies against dengue virus type 2. J Virol, 84(18), 9227-9239.

doi:10.1128/JVI.01087-10

Sukupolvi-Petty, S., Brien, J. D., Austin, S. K., Shrestha, B., Swayne, S., Kahle, K., .. .

Diamond, M. S. (2013). Functional analysis of antibodies against dengue virus type 4

reveals strain-dependent epitope exposure that impacts neutralization and protection. $J$ Virol, 87(16), 8826-8842. doi:10.1128/JVI.01314-13

Teoh, E. P., Kukkaro, P., Teo, E. W., Lim, A. P., Tan, T. T., Yip, A., . . MacAry, P. A. (2012).

The structural basis for serotype-specific neutralization of dengue virus by a human antibody. Sci Transl Med, 4(139), 139ra183. doi:10.1126/scitranslmed.3003888

Tharakaraman, K., Robinson, L. N., Hatas, A., Chen, Y. L., Siyue, L., Raguram, S., . . . Sasisekharan, R. (2013). Redesign of a cross-reactive antibody to dengue virus with broad-spectrum activity and increased in vivo potency. Proc Natl Acad Sci U S A, 110(17), E1555-1564. doi:10.1073/pnas.1303645110

Thein, T. L., Leo, Y. S., Lee, V. J., Sun, Y., \& Lye, D. C. (2011). Validation of probability equation and decision tree in predicting subsequent dengue hemorrhagic fever in adult dengue inpatients in Singapore. Am J Trop Med Hyg, 85(5), 942-945. doi:10.4269/ajtmh.2011.11-0149

Tsai, W. Y., Durbin, A., Tsai, J. J., Hsieh, S. C., Whitehead, S., \& Wang, W. K. (2015). Complexity of Neutralizing Antibodies against Multiple Dengue Virus Serotypes after Heterotypic Immunization and Secondary Infection Revealed by In-Depth Analysis of Cross-Reactive Antibodies. J Virol, 89(14), 7348-7362. doi:10.1128/JVI.00273-15

Tsai, W. Y., Lai, C. Y., Wu, Y. C., Lin, H. E., Edwards, C., Jumnainsong, A., . . Wang, W. K. (2013). High-avidity and potently neutralizing cross-reactive human monoclonal antibodies derived from secondary dengue virus infection. J Virol, 87(23), 12562-12575. doi:10.1128/JVI.00871-13

Tzarum, N., Giang, E., Kong, L., He, L., Prentoe, J., Augestad, E., . . Law, M. (2019). Genetic and structural insights into broad neutralization of hepatitis $\mathrm{C}$ virus by human $\mathrm{VH} 1-69$ antibodies. Sci Adv, 5(1), eaav1882. doi:10.1126/sciadv.aav1882

Vogt, M. R., Moesker, B., Goudsmit, J., Jongeneelen, M., Austin, S. K., Oliphant, T., . . . Diamond, M. S. (2009). Human monoclonal antibodies against West Nile virus induced by natural infection neutralize at a postattachment step. J Virol, 83(13), 6494-6507. doi:10.1128/JVI.00286-09

Walker, L. M., Phogat, S. K., Chan-Hui, P. Y., Wagner, D., Phung, P., Goss, J. L., . . Burton, D. R. (2009). Broad and potent neutralizing antibodies from an African donor reveal a new HIV-1 vaccine target. Science, 326(5950), 285-289. doi:10.1126/science.1178746

Waltari, E., McGeever, A., Friedland, N., Kim, P. S., \& McCutcheon, K. M. (2019). Functional Enrichment and Analysis of Antigen-Specific Memory B Cell Antibody Repertoires in PBMCs. Front Immunol, 10, 1452. doi:10.3389/fimmu.2019.01452

Woda, M., \& Mathew, A. (2015). Fluorescently labeled dengue viruses as probes to identify antigen-specific memory B cells by multiparametric flow cytometry. J Immunol Methods, 416, 167-177. doi:10.1016/j.jim.2014.12.001

Wrammert, J., Onlamoon, N., Akondy, R. S., Perng, G. C., Polsrila, K., Chandele, A., . . . Ahmed, R. (2012). Rapid and massive virus-specific plasmablast responses during acute dengue virus infection in humans. J Virol, 86(6), 2911-2918. doi:10.1128/JVI.06075-11

Wu, X., Yang, Z. Y., Li, Y., Hogerkorp, C. M., Schief, W. R., Seaman, M. S., . . Mascola, J. R. (2010). Rational design of envelope identifies broadly neutralizing human monoclonal antibodies to HIV-1. Science, 329(5993), 856-861. doi:10.1126/science.1187659

Wu, X., Zhou, T., Zhu, J., Zhang, B., Georgiev, I., Wang, C., . . Mascola, J. R. (2011). Focused evolution of HIV-1 neutralizing antibodies revealed by structures and deep sequencing. Science, 333(6049), 1593-1602. doi:10.1126/science.1207532 
Xu, M., Hadinoto, V., Appanna, R., Joensson, K., Toh, Y. X., Balakrishnan, T., . . Fink, K. (2012). Plasmablasts generated during repeated dengue infection are virus glycoproteinspecific and bind to multiple virus serotypes. J Immunol, 189(12), 5877-5885. doi:10.4049/jimmunol.1201688

Xu, M., Zuest, R., Velumani, S., Tukijan, F., Toh, Y. X., Appanna, R., . . Fink, K. (2017). A potent neutralizing antibody with therapeutic potential against all four serotypes of dengue virus. NPJ Vaccines, 2, 2. doi:10.1038/s41541-016-0003-3

Xu, M., Zust, R., Toh, Y. X., Pfaff, J. M., Kahle, K. M., Davidson, E., . . Fink, K. (2016). Protective Capacity of the Human Anamnestic Antibody Response during Acute Dengue Virus Infection. J Virol, 90(24), 11122-11131. doi:10.1128/JVI.01096-16

Yu, I. M., Zhang, W., Holdaway, H. A., Li, L., Kostyuchenko, V. A., Chipman, P. R., . . Chen, J. (2008). Structure of the immature dengue virus at low $\mathrm{pH}$ primes proteolytic maturation. Science, 319(5871), 1834-1837. doi:10.1126/science.1153264

Zanini, F., Robinson, M. L., Croote, D., Sahoo, M. K., Sanz, A. M., Ortiz-Lasso, E., .. . Einav, S. (2018). Virus-inclusive single-cell RNA sequencing reveals the molecular signature of progression to severe dengue. Proc Natl Acad Sci U S A, 115(52), E12363-E12369. doi:10.1073/pnas.1813819115

Zhang, X., Ge, P., Yu, X., Brannan, J. M., Bi, G., Zhang, Q., . . Zhou, Z. H. (2013). Cryo-EM structure of the mature dengue virus at 3.5-A resolution. Nat Struct Mol Biol, 20(1), 105110. doi:10.1038/nsmb.2463

Zhang, Y., Corver, J., Chipman, P. R., Zhang, W., Pletnev, S. V., Sedlak, D., . . Rossmann, M. G. (2003). Structures of immature flavivirus particles. EMBO J, 22(11), 2604-2613. doi:10.1093/emboj/cdg270

Zhang, Y., Kaufmann, B., Chipman, P. R., Kuhn, R. J., \& Rossmann, M. G. (2007). Structure of immature West Nile virus. J Virol, 81(11), 6141-6145. doi:10.1128/JVI.00037-07

Zhou, J. Q., \& Kleinstein, S. H. (2019). Cutting Edge: Ig H Chains Are Sufficient to Determine Most B Cell Clonal Relationships. J Immunol, 203(7), 1687-1692.

doi:10.4049/jimmunol.1900666 
bioRxiv preprint doi: https://doi.org/10.1101/790642; this version posted October 2, 2019. The copyright holder for this preprint (which was not certified by peer review) is the author/funder, who has granted bioRxiv a license to display the preprint in perpetuity. It is made available under aCC-BY-NC 4.0 International license.

Figure 1

A

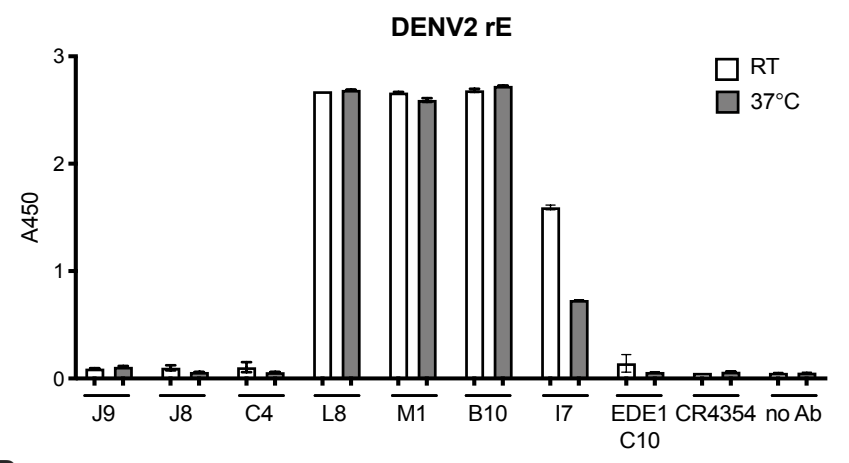

B

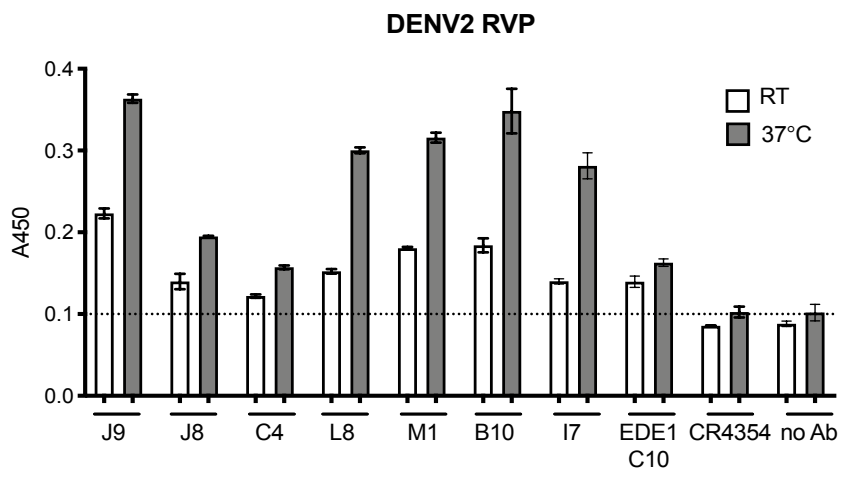

C

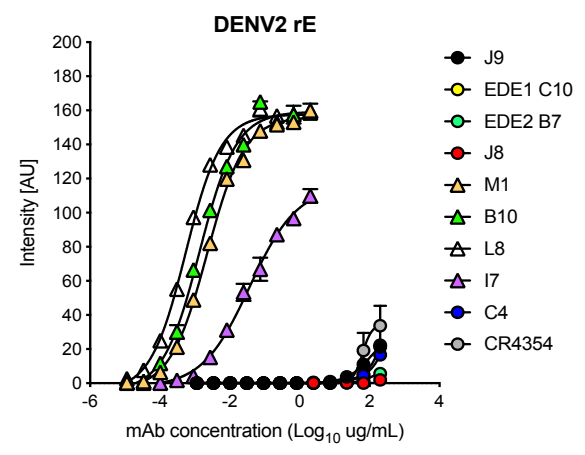

D

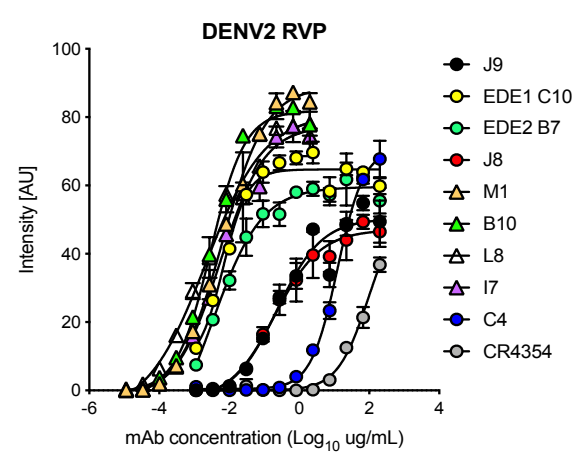




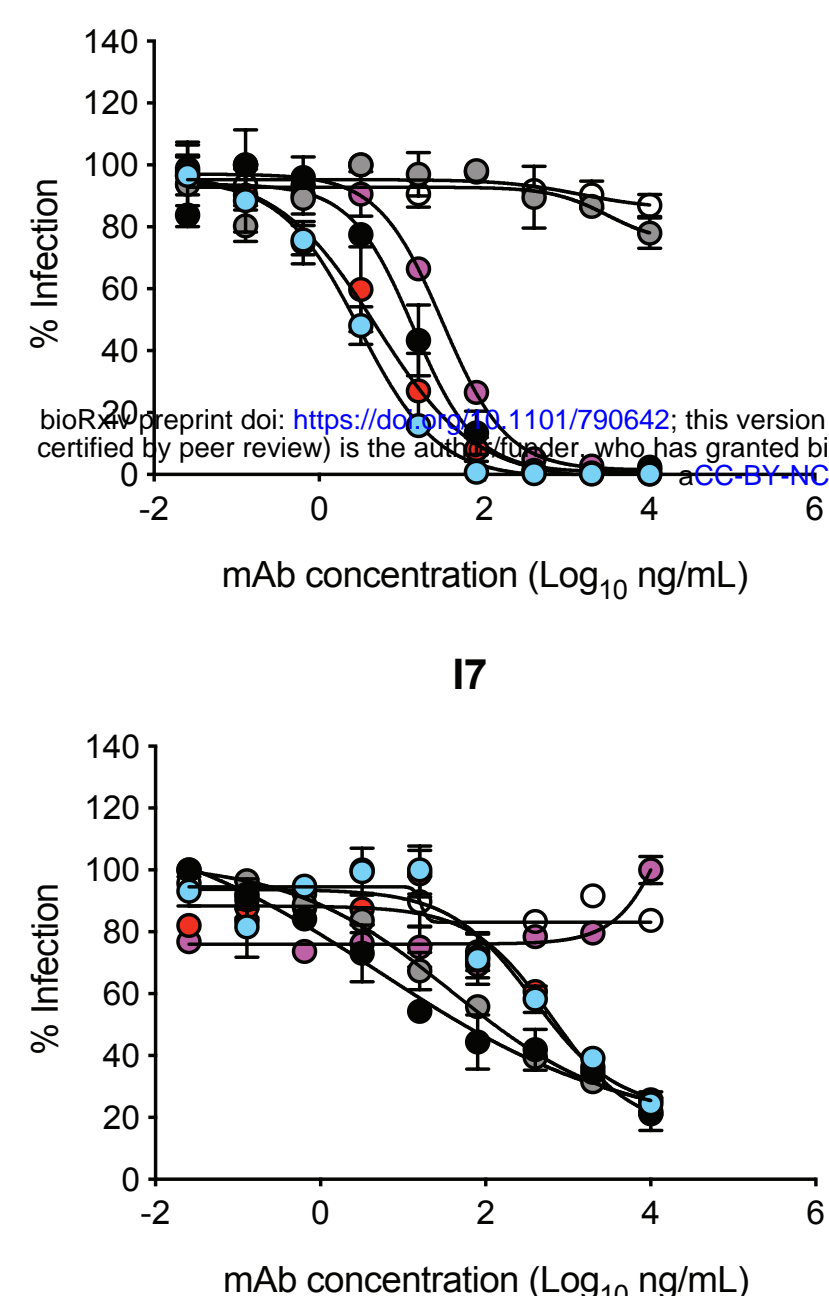

L8

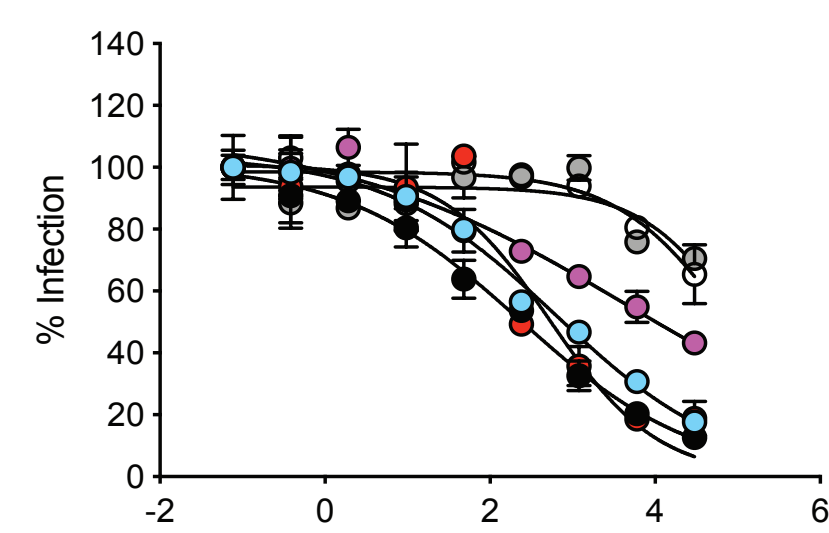

mAb concentration $\left(\log _{10} \mathrm{ng} / \mathrm{mL}\right)$

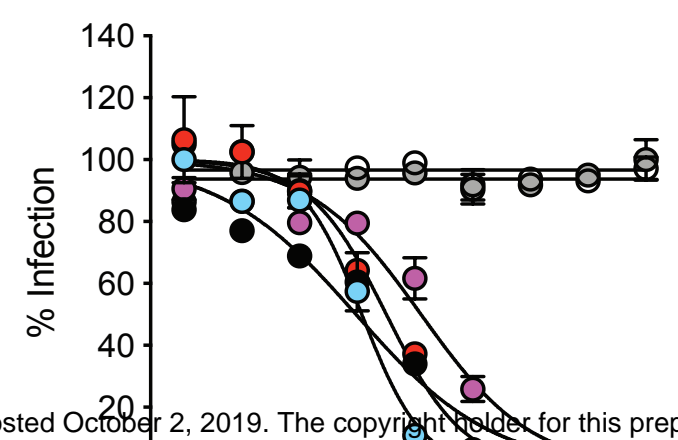

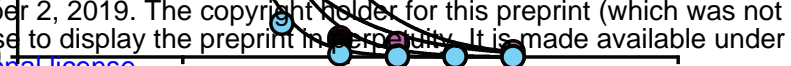

$\mathrm{mAb}$ concentration $\left(\log _{10} \mathrm{ng} / \mathrm{mL}\right)$

M1

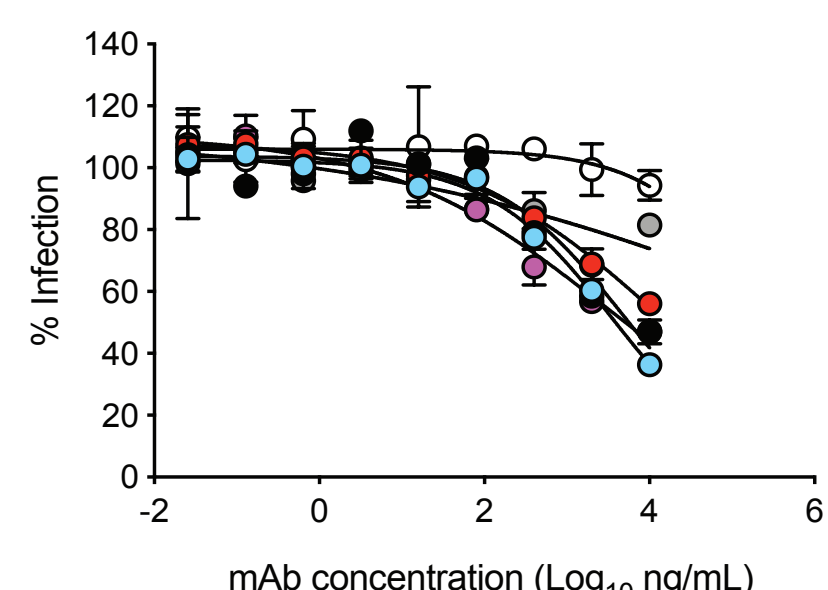

EDE1 C10

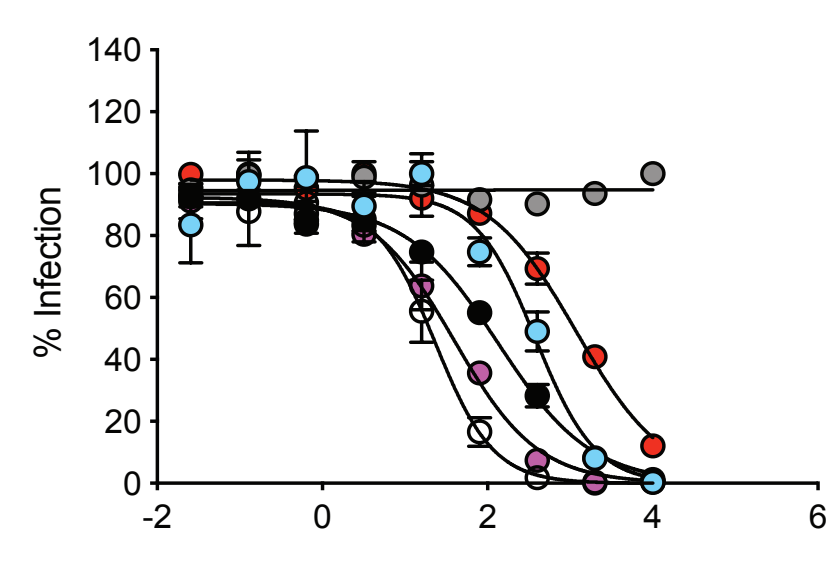

$\mathrm{mAb}$ concentration $\left(\log _{10} \mathrm{ng} / \mathrm{mL}\right)$

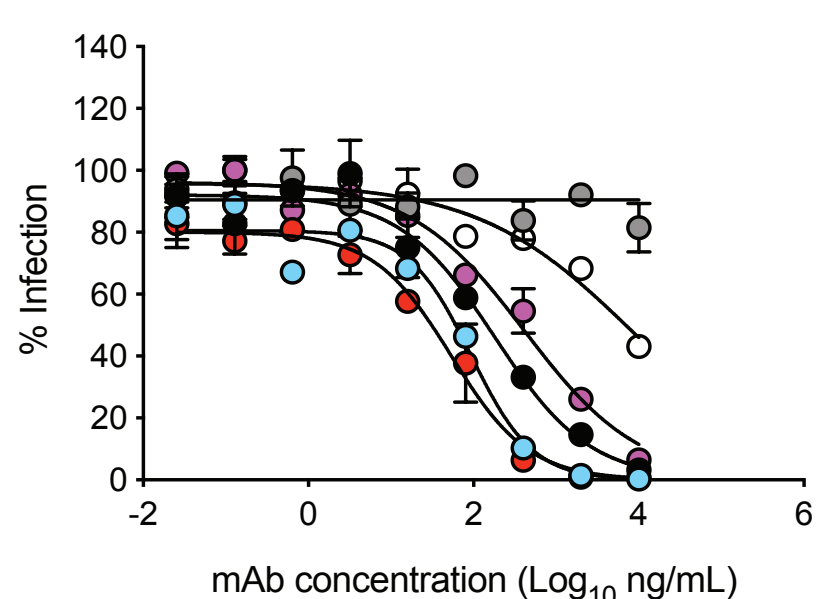

B10

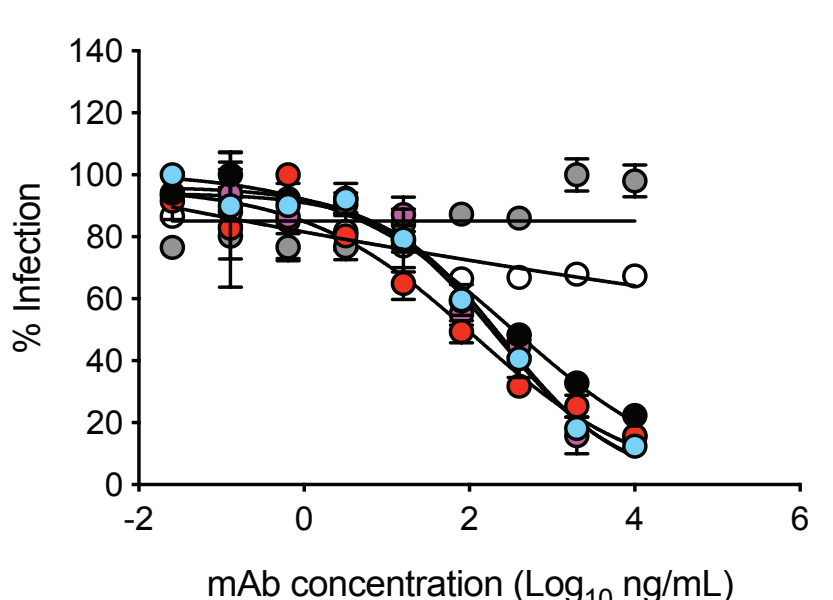

EDE2 B7

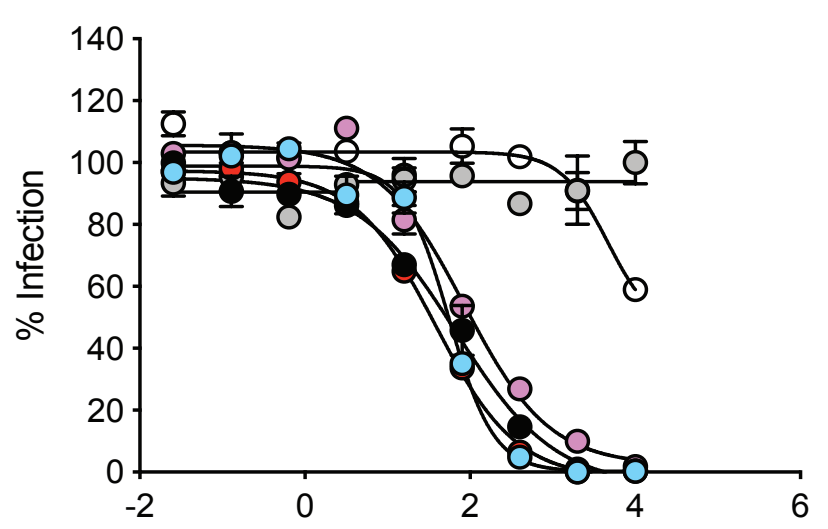

$\mathrm{mAb}$ concentration $\left(\log _{10} \mathrm{ng} / \mathrm{mL}\right)$

B

\begin{tabular}{|c|c|c|c|c|c|c|c|c|c|c|}
\hline & \multicolumn{2}{|c|}{ Shared clonal family } & \multirow[b]{2}{*}{ Pt 013} & \multirow[b]{2}{*}{ Pt 013} & \multicolumn{2}{|c|}{ Shared clonal family } & \multirow[b]{2}{*}{ Pt 020} & & & \\
\hline & Pt 013 & Pt 013 & & & Pt 013 & Pt 020 & & & & \\
\hline & J9 & J8 & C4 & 17 & M1 & B10 & L8 & EDE1 C10 & EDE2 B7 & CR4354 \\
\hline DENV1 & 6 & 9 & 69 & 1751 & 1091 & 757 & 360 & 352 & 91 & \\
\hline DENV2 & 30 & 18 & 262 & 1142 & 937 & 929 & 177 & 171 & 64 & \\
\hline DENV3 & 15 & 13 & 36 & 1771 & 2156 & 499 & 292 & 753 & 45 & \\
\hline DENV4 & 39 & 70 & 1624 & & 900 & 698 & 2454 & 38 & 206 & \\
\hline ZIKV & & & & & & & & 38 & & \\
\hline WNV & & & & 620 & & & & & & 7 \\
\hline
\end{tabular}


Figure 3

$\begin{array}{llll}\text { A } & \text { C4 } & \text { B }\end{array}$

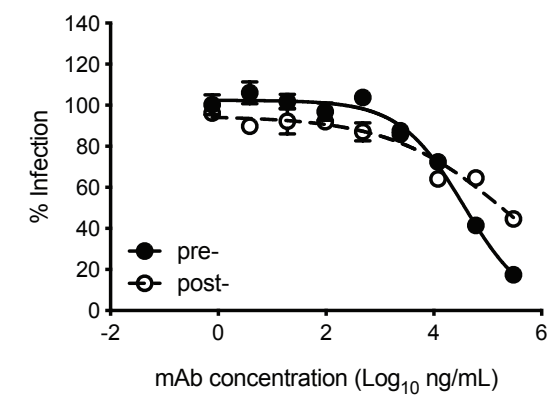

C

J8

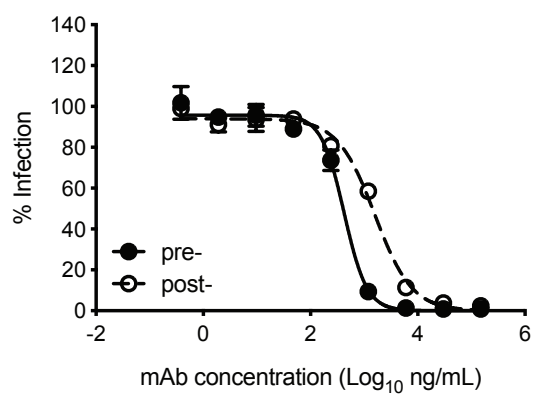

D
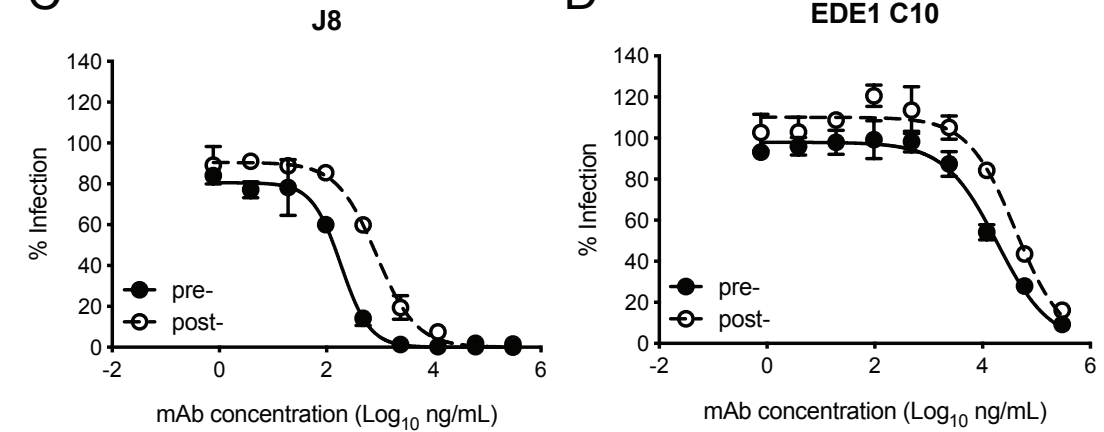
Figure 4 aCC-BY-NC 4.0 International license.

A
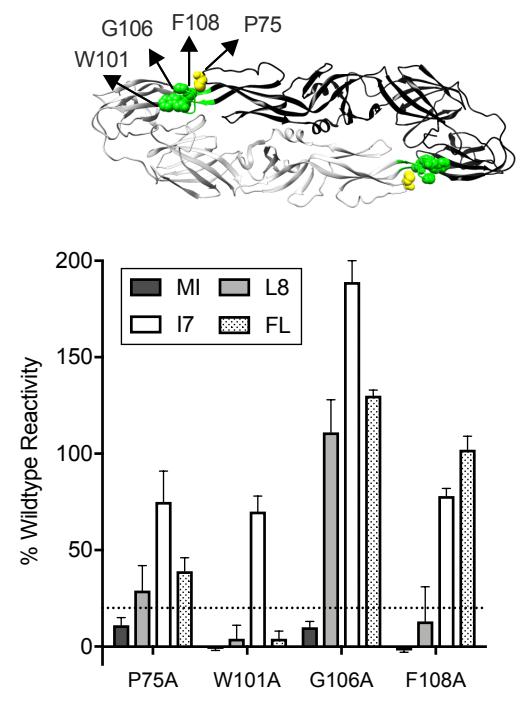

B
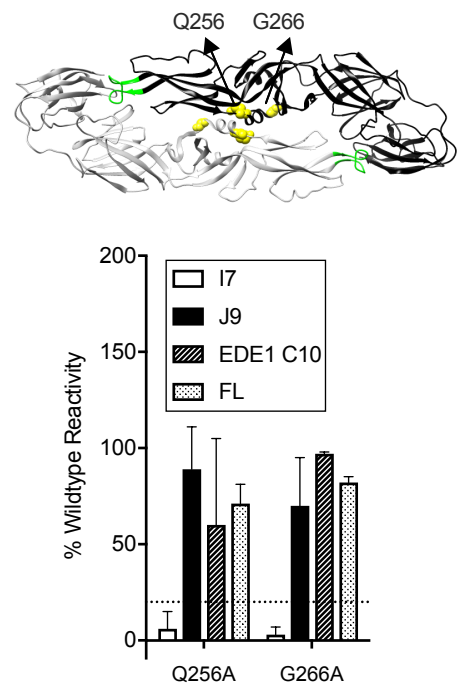

C

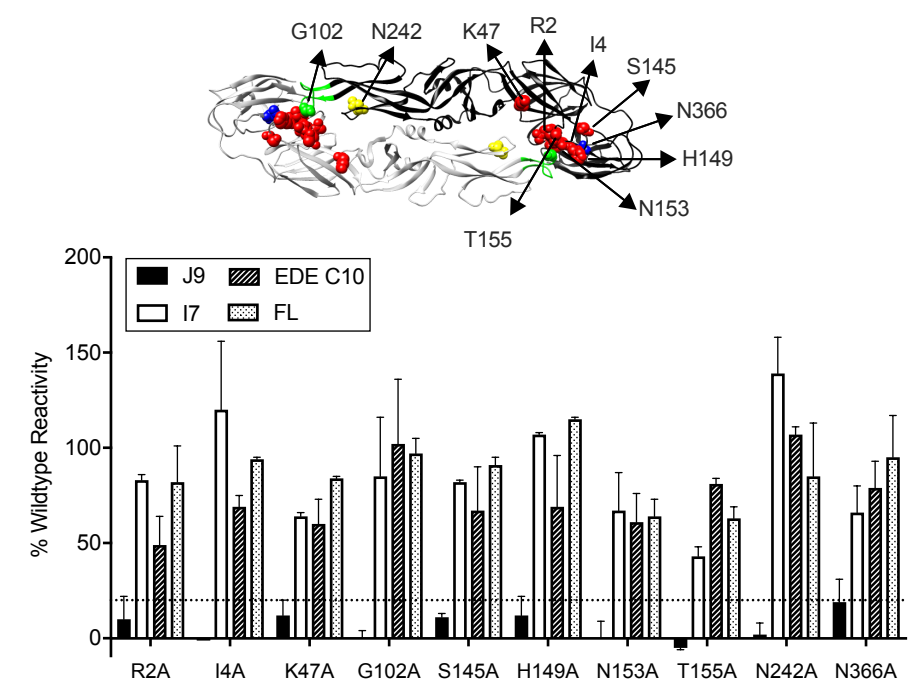


bioRxiv preprint doi: https://doi.org/10.1101/790642; this version posted October 2, 2019. The copyright holder for this preprint (which was not certified by peer review) is the author/funder, who has granted bioRxiv a license to display the preprint in perpetuity. It is made available under Figure 5

A

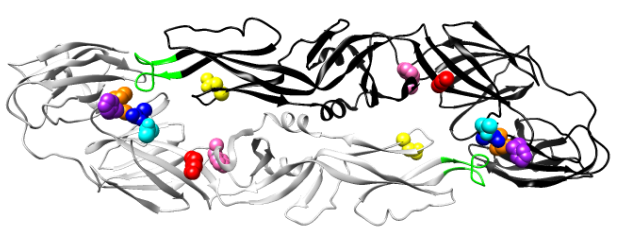

C

$\mathrm{J} 8$

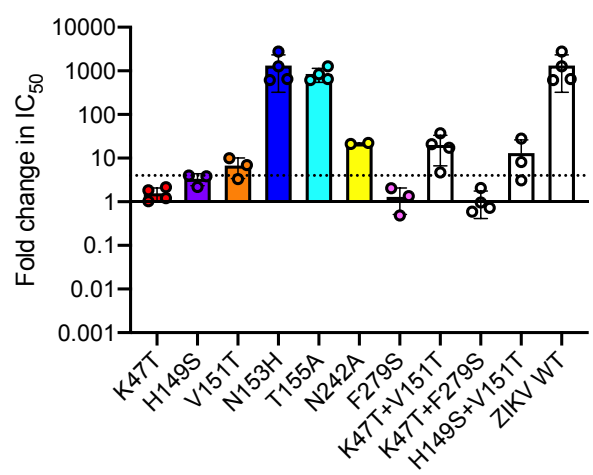

E

EDE1 C10

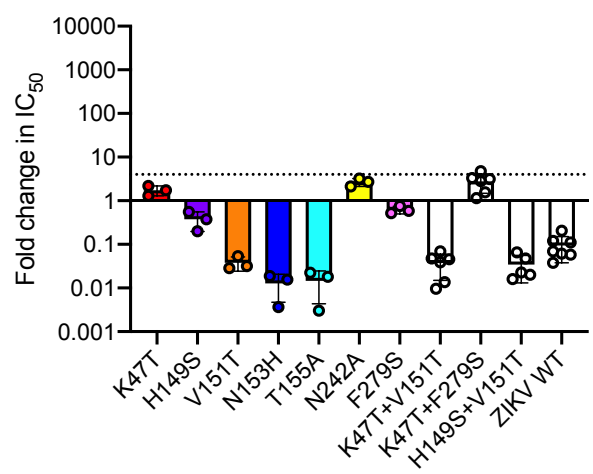

B

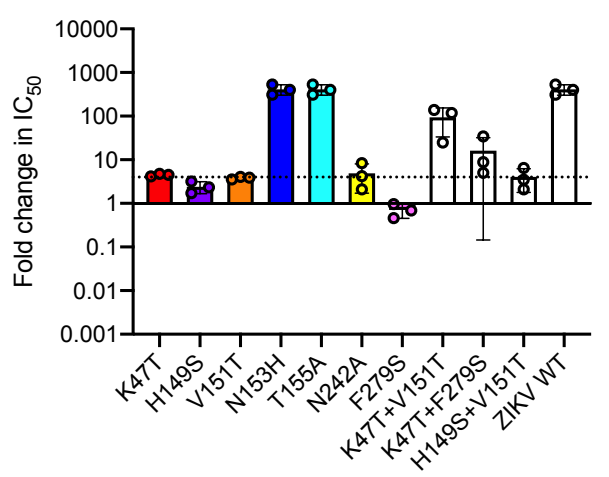

D

C4

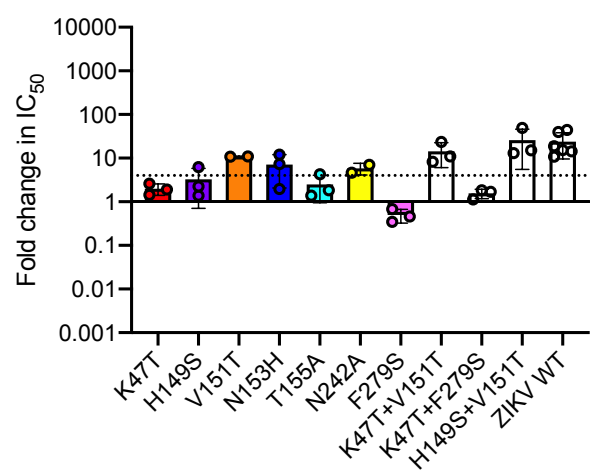

F

EDE2 B7

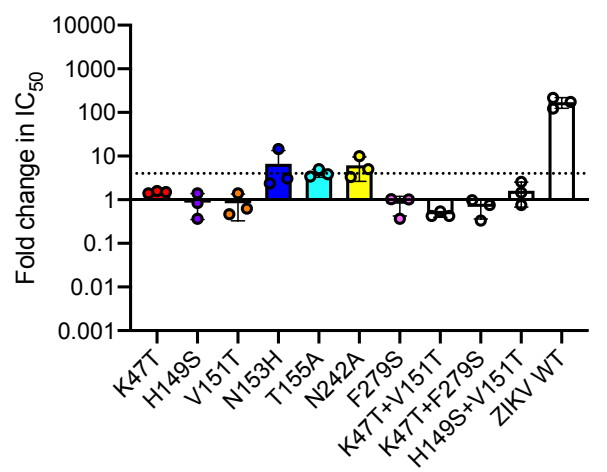


Figure 6 bioRxiv preprint doi: https://doi.org/10.1101/790642; this version posted October 2, 2019. The copyright holder for this preprint (which was not certified by peer review) is the author/funder, who has granted bioRxiv a license to display the preprint in perpetuity. It is made available under A aCC-BY-NC 4.0 International license.

B
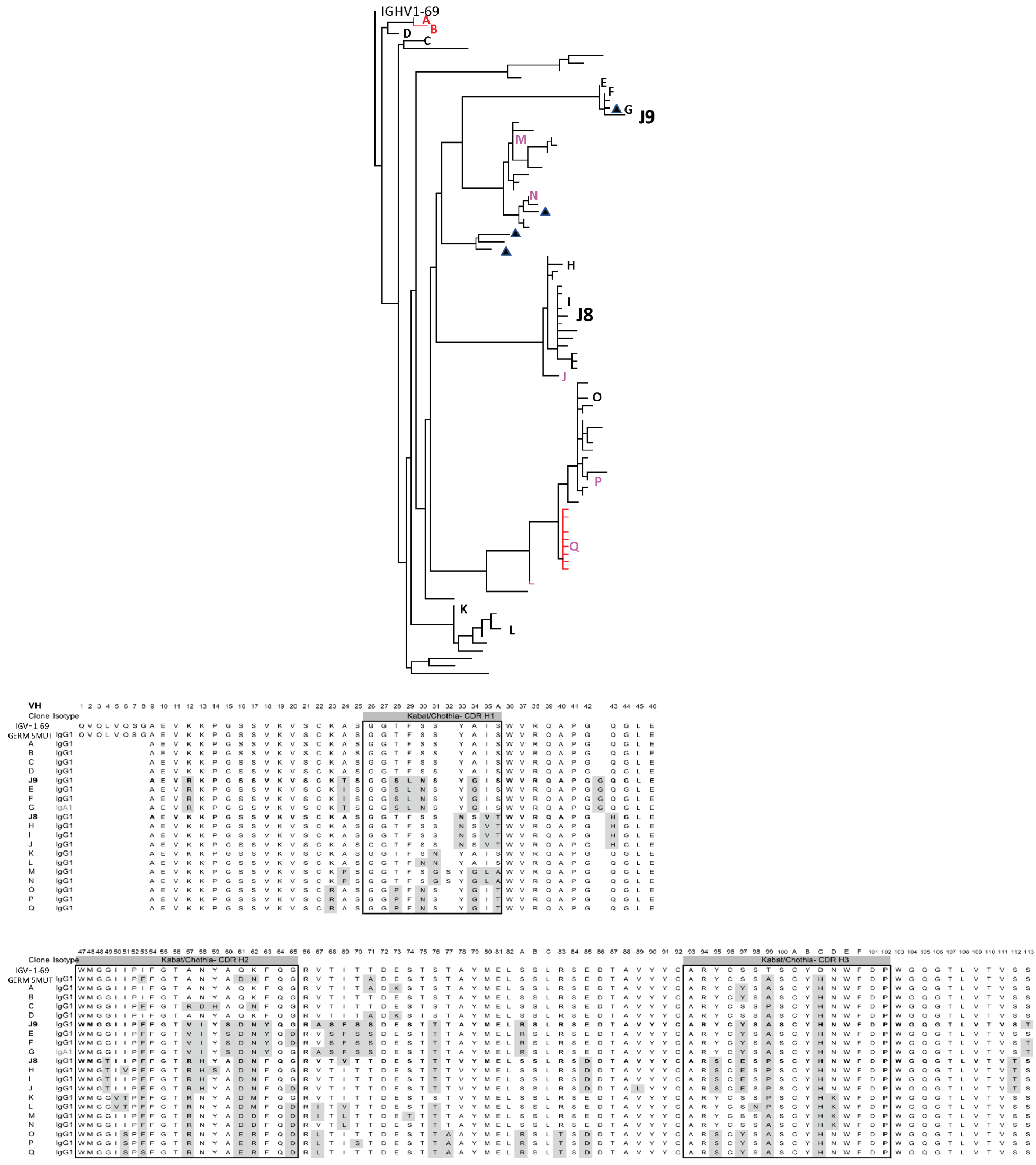

C

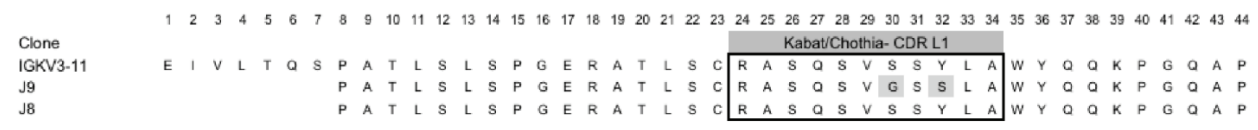

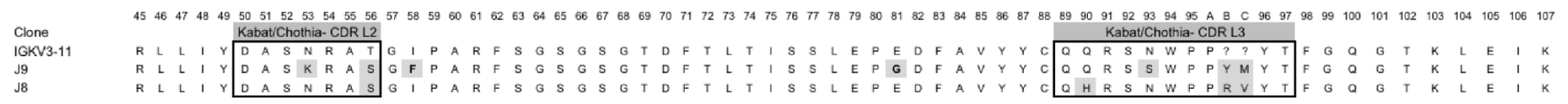


bioRxiv preprint doi: https://doi.org/10.1101/790642; this version posted October 2, 2019. The copyright holder for this preprint (which was not certified by peer review) is the author/funder, who has granted bioRxiv a license to display the preprint in perpetuity. It is made available under Figure 7

A

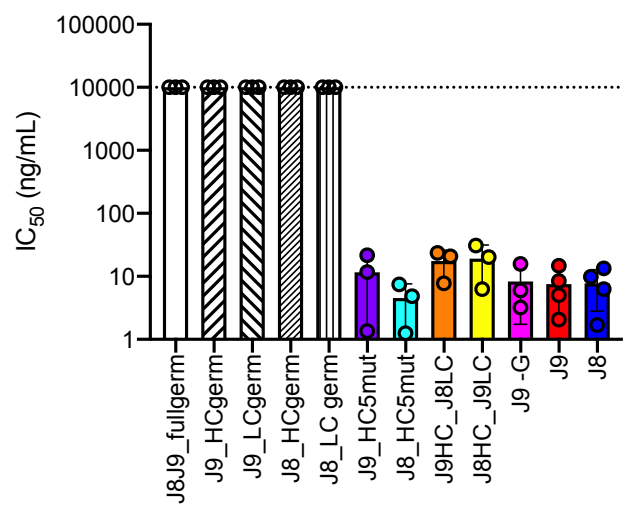

B

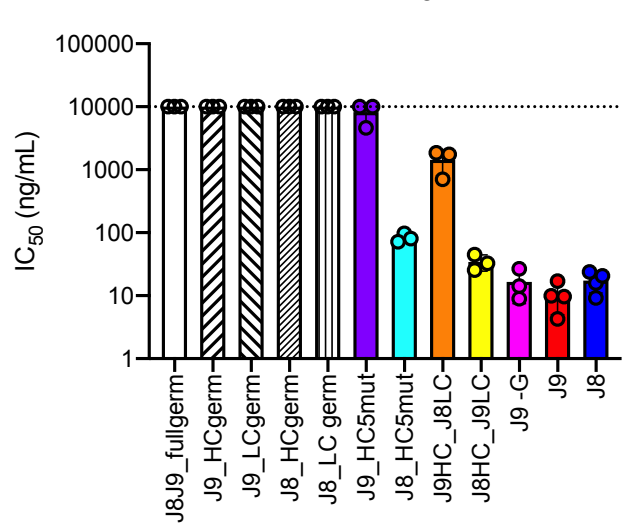

C

DENV2

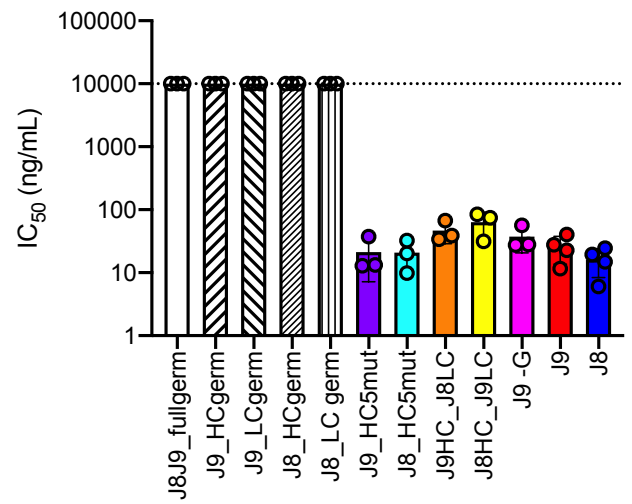

$\mathrm{D}$

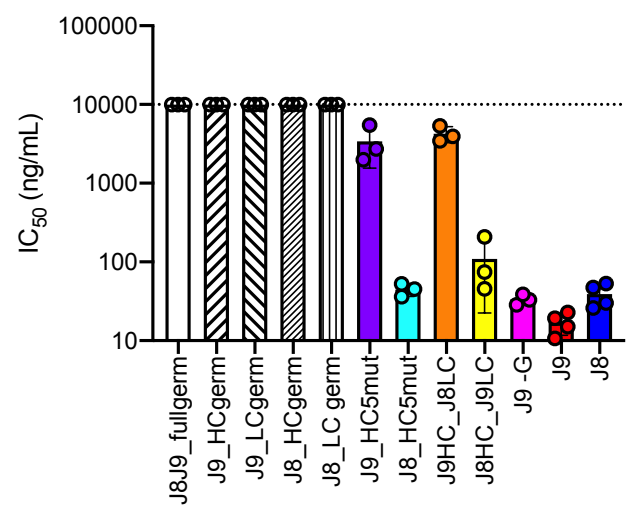



aCC-BY-NC 4.0 International license.

Table S1. Percent mAb binding reactivity to DENV2 E protein alanine scanning mutagenesis library normalized to wildtype DENV2

\begin{tabular}{|c|c|c|c|c|c|c|c|c|c|c|c|c|}
\hline & \multicolumn{2}{|c|}{ J9 } & \multicolumn{2}{|c|}{17} & \multicolumn{2}{|c|}{ M1 } & \multicolumn{2}{|c|}{ L8 } & \multicolumn{2}{|c|}{ EDE1 C10 } & \multicolumn{2}{|c|}{$\mathbf{F L}$} \\
\hline Mutation & Mean & Range & Mean & Range & Mean & Range & Mean & Range & Mean & Range & Mean & Range \\
\hline M1A & -2 & 4 & 83 & 3 & 48 & 2 & 44 & 6 & 4 & 2 & 87 & 0 \\
\hline R2A & 10 & 12 & 83 & 3 & 49 & 8 & 54 & 6 & 49 & 15 & 82 & 19 \\
\hline C3A & 5 & 16 & 37 & 17 & 30 & 3 & 24 & 7 & -4 & 2 & 49 & 7 \\
\hline I4A & -1 & 0 & 120 & 36 & 77 & 15 & 67 & 15 & 69 & 6 & 94 & 1 \\
\hline G5A & -3 & 2 & 91 & 3 & 49 & 9 & 46 & 14 & -2 & 5 & 87 & 3 \\
\hline M6A & 89 & 17 & 121 & 39 & 98 & 3 & 96 & 8 & 82 & 10 & 126 & 29 \\
\hline S7A & 82 & 46 & 127 & 18 & 78 & 9 & 77 & 15 & 106 & 3 & 111 & 7 \\
\hline N8A & 79 & 12 & 60 & 0 & 76 & 13 & 60 & 4 & 99 & 19 & 81 & 14 \\
\hline R9A & 2 & 13 & 52 & 7 & 36 & 3 & 39 & 8 & -1 & 1 & 70 & 8 \\
\hline D10A & 97 & 45 & 132 & 2 & 88 & 28 & 100 & 8 & 119 & 27 & 116 & 4 \\
\hline $\mathrm{F} 11 \mathrm{~A}$ & 14 & 24 & 76 & 77 & & & & & -3 & 17 & 51 & 10 \\
\hline V12A & 75 & 10 & 90 & 62 & & & & & 118 & 5 & 76 & 9 \\
\hline E13A & 63 & 38 & 79 & 22 & 75 & 5 & 74 & 4 & 90 & 16 & 83 & 6 \\
\hline G14A & 87 & 44 & 164 & 37 & 86 & 5 & 102 & 3 & 92 & 19 & 86 & 16 \\
\hline V15A & 90 & 23 & 100 & 14 & 86 & 17 & 94 & 2 & 141 & 18 & 111 & 13 \\
\hline S16A & 101 & 9 & 149 & 76 & 93 & 27 & 89 & 20 & 135 & 51 & 104 & 6 \\
\hline G17A & 91 & 3 & 132 & 77 & 81 & 7 & 76 & 24 & 130 & 29 & 98 & 22 \\
\hline G18A & 131 & 29 & 126 & 24 & 94 & 1 & 120 & 23 & 120 & 34 & 116 & 7 \\
\hline S19A & 113 & 39 & 117 & 45 & 87 & 11 & 85 & 29 & 108 & 62 & 97 & 17 \\
\hline W20A & 119 & 45 & 83 & 23 & 66 & 7 & 63 & 19 & 77 & 25 & 99 & 19 \\
\hline V21A & 59 & 4 & 49 & 3 & 66 & 17 & 65 & 4 & 93 & 23 & 81 & 10 \\
\hline D22A & 17 & 7 & 14 & 13 & 23 & 2 & 28 & 4 & 34 & 33 & 32 & 2 \\
\hline I23A & 15 & 4 & 5 & 7 & 8 & 5 & 13 & 4 & 7 & 4 & 26 & 1 \\
\hline V24A & 66 & 22 & 93 & 0 & 76 & 9 & 80 & 21 & 87 & 41 & 86 & 2 \\
\hline L25A & 6 & 8 & -5 & 5 & 2 & 3 & 2 & 1 & 1 & 1 & 13 & 1 \\
\hline E26A & 74 & 18 & 96 & 24 & 80 & 3 & 80 & 6 & 116 & 23 & 95 & 5 \\
\hline $\mathrm{H} 27 \mathrm{~A}$ & 44 & 9 & 73 & 10 & 72 & 23 & 80 & 22 & 80 & 3 & 93 & 10 \\
\hline G28A & 34 & 1 & 53 & 50 & & & & & 68 & 21 & 50 & 6 \\
\hline S29A & 130 & 6 & 137 & 9 & 77 & 26 & 88 & 16 & 79 & 17 & 108 & 18 \\
\hline C30A & 2 & 5 & 27 & 14 & 21 & 8 & 23 & 4 & -1 & 5 & 43 & 5 \\
\hline V31A & 47 & 1 & 27 & 7 & 30 & 15 & 37 & 9 & 52 & 14 & 51 & 6 \\
\hline T32A & 4 & 7 & 6 & 1 & 7 & 5 & 7 & 0 & -1 & 5 & 21 & 3 \\
\hline T33A & 118 & 16 & 116 & 15 & 93 & 9 & 95 & 3 & 98 & 57 & 112 & 23 \\
\hline M34A & 2 & 2 & 34 & 5 & 30 & 6 & 34 & 12 & 3 & 3 & 66 & 6 \\
\hline A35S & 88 & 22 & 122 & 13 & 71 & 22 & 69 & 8 & 66 & 6 & 99 & 10 \\
\hline K36A & 120 & 29 & 115 & 18 & 83 & 20 & 83 & 1 & 69 & 1 & 106 & 5 \\
\hline N37A & 68 & 11 & 68 & 14 & 50 & 10 & 56 & 6 & 67 & 14 & 78 & 6 \\
\hline K38A & 54 & 6 & 71 & 28 & 55 & 15 & 61 & 1 & 75 & 12 & 77 & 4 \\
\hline P39A & 2 & 1 & 27 & 7 & 19 & 3 & 22 & 4 & 4 & 3 & 41 & 3 \\
\hline T40A & -1 & 0 & 55 & 11 & 37 & 2 & 34 & 1 & 4 & 6 & 62 & 4 \\
\hline L41A & -3 & 0 & 2 & 1 & 2 & 1 & 5 & 2 & -4 & 1 & 15 & 2 \\
\hline D42A & 5 & 6 & 19 & 0 & 19 & 7 & 19 & 1 & 0 & 2 & 43 & 0 \\
\hline $\mathrm{F} 43 \mathrm{~A}$ & 25 & 5 & 6 & 10 & 16 & 9 & 19 & 6 & 22 & 0 & 25 & 2 \\
\hline
\end{tabular}


bioRxiv preprint doi: https://doi.org/10.1101/790642; this version posted October 2, 2019. The copyright holder for this preprint (which was not certified by peer review) is the author/funder, who has granted bioRxiv a license to display the preprint in perpetuity. It is made available under aCC-BY-NC 4.0 International license.

\begin{tabular}{|c|c|c|c|c|c|c|c|c|c|c|c|c|}
\hline E44A & 81 & 4 & 118 & 5 & 87 & 9 & 81 & 5 & 72 & 41 & 102 & 7 \\
\hline L45A & -2 & 3 & -5 & 10 & 0 & 2 & 1 & 0 & 0 & 4 & 6 & 1 \\
\hline $146 \mathrm{~A}$ & 19 & 8 & 25 & 3 & 33 & 7 & 30 & 10 & 44 & 0 & 57 & 7 \\
\hline K47A & 12 & 8 & 64 & 2 & 57 & 20 & 61 & 1 & 60 & 13 & 84 & 1 \\
\hline T48A & 55 & 7 & 91 & 21 & 80 & 36 & 81 & 1 & 68 & 16 & 89 & 9 \\
\hline E49A & 74 & 11 & 68 & 33 & 62 & 16 & 62 & 15 & 85 & 17 & 79 & 4 \\
\hline A50S & 55 & 6 & 74 & 44 & 60 & 23 & 60 & 17 & 55 & 15 & 83 & 1 \\
\hline K51A & 46 & 20 & 45 & 17 & 60 & 11 & 54 & 10 & 58 & 0 & 74 & 3 \\
\hline Q52A & 108 & 27 & 99 & 41 & 82 & 16 & 107 & 16 & 114 & 63 & 106 & 7 \\
\hline P53A & 98 & 37 & 170 & 0 & 90 & 35 & 93 & 3 & 102 & 9 & 124 & 1 \\
\hline A54S & 91 & 10 & 150 & 6 & 87 & 28 & 89 & 15 & 115 & 14 & 108 & 1 \\
\hline T55A & 63 & 31 & 60 & 15 & 45 & 23 & 60 & 5 & 64 & 14 & 85 & 9 \\
\hline L56A & 15 & 9 & -4 & 5 & 6 & 3 & 5 & 1 & 14 & 4 & 25 & 1 \\
\hline R57A & 7 & 1 & -6 & 8 & 0 & 1 & 4 & 4 & 0 & 1 & 8 & 4 \\
\hline K58A & 53 & 20 & 30 & 1 & 33 & 16 & 31 & 3 & 60 & 5 & 58 & 3 \\
\hline Y59A & -2 & 2 & -5 & 7 & 0 & 2 & 2 & 2 & -3 & 0 & 5 & 1 \\
\hline C60A & -3 & 0 & -5 & 7 & -1 & 2 & 1 & 1 & 2 & 4 & 2 & 1 \\
\hline $161 \mathrm{~A}$ & 3 & 7 & -4 & 4 & 0 & 3 & 2 & 3 & 0 & 5 & 6 & 1 \\
\hline E62A & 79 & 36 & 76 & 1 & 63 & 25 & 54 & 14 & 73 & 2 & 94 & 4 \\
\hline A63S & 31 & 13 & 6 & 9 & 6 & 2 & 8 & 5 & 14 & 1 & 31 & 5 \\
\hline K64A & 149 & 6 & 186 & 4 & 100 & 11 & 116 & 27 & 130 & 20 & 130 & 8 \\
\hline L65A & 80 & 44 & 37 & 11 & 54 & 11 & 59 & 9 & 64 & 4 & 72 & 8 \\
\hline T66A & 55 & 15 & 49 & 11 & 53 & 19 & 58 & 12 & 93 & 5 & 78 & 7 \\
\hline N67A & 38 & 2 & 12 & 7 & 20 & 2 & 19 & 0 & 62 & 0 & 37 & 1 \\
\hline T68A & 90 & 61 & 109 & 9 & 76 & 32 & 80 & 9 & 93 & 18 & 90 & 4 \\
\hline T69A & 58 & 5 & 35 & 11 & 30 & 6 & 34 & 4 & 86 & 1 & 45 & 1 \\
\hline T70A & 42 & 7 & 36 & 10 & 27 & 8 & 31 & 1 & 61 & 16 & 52 & 3 \\
\hline E71A & 149 & 89 & 182 & 54 & 94 & 22 & 112 & 12 & 162 & 21 & 110 & 21 \\
\hline S72A & 119 & 0 & 122 & 12 & 80 & 20 & 88 & 9 & 114 & 32 & 104 & 6 \\
\hline R73A & 92 & 40 & 124 & 22 & 86 & 23 & 78 & 16 & 71 & 7 & 104 & 3 \\
\hline C74A & 1 & 2 & 1 & 4 & -2 & 1 & 0 & 0 & 4 & 9 & 0 & 0 \\
\hline P75A & 11 & 2 & 75 & 16 & 11 & 4 & 29 & 13 & 4 & 4 & 39 & 7 \\
\hline T76A & 132 & 45 & 138 & 10 & 116 & 11 & 104 & 11 & 147 & 42 & 118 & 3 \\
\hline Q77A & 109 & 38 & 117 & 20 & 65 & 8 & 75 & 7 & 72 & 28 & 103 & 21 \\
\hline G78A & 67 & 16 & 52 & 11 & 46 & 21 & 59 & 11 & 44 & 9 & 82 & 1 \\
\hline E79A & 0 & 2 & -2 & 9 & 0 & 5 & 0 & 0 & -1 & 1 & 3 & 1 \\
\hline P80A & 80 & 33 & 92 & 9 & 54 & 5 & 60 & 14 & 79 & 38 & 70 & 4 \\
\hline S81A & 110 & 38 & 106 & 9 & 76 & 6 & 80 & 25 & 92 & 10 & 99 & 19 \\
\hline L82A & 40 & 11 & 41 & 13 & 12 & 8 & 23 & 5 & 57 & 11 & 45 & 5 \\
\hline N83A & 119 & 2 & 195 & 37 & 100 & 5 & 114 & 7 & 151 & 66 & 130 & 47 \\
\hline E84A & 64 & 18 & 79 & 35 & 59 & 16 & 74 & 29 & 65 & 30 & 83 & 21 \\
\hline E85A & 25 & 13 & 30 & 2 & 16 & 3 & 22 & 5 & 29 & 4 & 42 & 4 \\
\hline Q86A & 71 & 8 & 90 & 21 & 104 & 8 & 91 & 19 & 72 & 59 & 109 & 8 \\
\hline D87A & -2 & 2 & -2 & 0 & -1 & 2 & 2 & 1 & 0 & 3 & 6 & 0 \\
\hline K88A & 106 & 12 & 138 & 52 & 113 & 4 & 108 & 8 & 108 & 12 & 106 & 1 \\
\hline R89A & 74 & 12 & 42 & 1 & 44 & 4 & 42 & 3 & 89 & 6 & 79 & 20 \\
\hline F90A & 7 & 9 & 9 & 3 & 4 & 3 & 7 & 1 & 7 & 8 & 21 & 1 \\
\hline V91A & 53 & 21 & 14 & 8 & 16 & 2 & 16 & 4 & 41 & 22 & 45 & 2 \\
\hline
\end{tabular}


bioRxiv preprint doi: https://doi.org/10.1101/790642; this version posted October 2, 2019. The copyright holder for this preprint (which was not certified by peer review) is the author/funder, who has granted bioRxiv a license to display the preprint in perpetuity. It is made available under aCC-BY-NC 4.0 International license.

\begin{tabular}{|c|c|c|c|c|c|c|c|c|c|c|c|}
\hline C92A & 1 & 10 & 3 & 1 & -2 & 2 & 0 & 0 & -6 & 0 & 3 \\
\hline K93A & 137 & 24 & 63 & 3 & 73 & 3 & 78 & 10 & 93 & 44 & 93 \\
\hline H94A & 33 & 12 & 30 & 6 & 18 & 6 & 20 & 2 & 31 & 18 & 40 \\
\hline S95A & 54 & 14 & 98 & 23 & 72 & 6 & 84 & 19 & 116 & 26 & 102 \\
\hline M96A & 90 & 2 & 70 & 11 & 75 & 14 & 83 & 6 & 60 & 1 & 86 \\
\hline V97A & 42 & 15 & 49 & 15 & 46 & 21 & 49 & 6 & 74 & 14 & 72 \\
\hline D98A & 1 & 3 & 50 & 3 & 25 & 8 & 33 & 0 & 10 & 4 & 62 \\
\hline R99A & 5 & 2 & 73 & 71 & & & & & -7 & 9 & 58 \\
\hline G100A & 2 & 1 & 73 & 58 & & & & & 5 & 23 & 36 \\
\hline W101A & -3 & 1 & 70 & 8 & -1 & 1 & 4 & 7 & -4 & 1 & 4 \\
\hline G102A & 0 & 4 & 85 & 31 & 69 & 14 & 50 & 4 & 102 & 34 & 97 \\
\hline N103A & -3 & 3 & 24 & 4 & 2 & 2 & 8 & 3 & -3 & 8 & 25 \\
\hline G104A & 26 & 3 & 33 & 4 & 12 & 2 & 16 & 5 & 2 & 4 & 35 \\
\hline C105A & -1 & 7 & 6 & 5 & 0 & 1 & 1 & 1 & -3 & 1 & 4 \\
\hline G106A & 161 & 62 & 189 & 12 & 10 & 3 & 111 & 17 & 172 & 12 & 130 \\
\hline L107A & 103 & 37 & 123 & 9 & 101 & 20 & 114 & 3 & 105 & 21 & 113 \\
\hline F108A & 0 & 6 & 78 & 4 & -2 & 1 & 13 & 18 & -3 & 1 & 102 \\
\hline G109A & 43 & 10 & 50 & 1 & 22 & 6 & 29 & 3 & 34 & 9 & 41 \\
\hline K110A & 45 & 1 & 83 & 15 & 55 & 2 & 51 & 4 & 50 & 1 & 69 \\
\hline G111A & 51 & 28 & 85 & 31 & 37 & 7 & 67 & 7 & 65 & 0 & 76 \\
\hline G112A & 101 & 31 & 169 & 82 & 116 & 8 & 96 & 1 & 126 & 52 & 124 \\
\hline I113A & 48 & 5 & 44 & 21 & 29 & 11 & 37 & 13 & 73 & 22 & 59 \\
\hline V114A & 33 & 12 & 20 & 11 & 14 & 1 & 20 & 12 & 29 & 28 & 39 \\
\hline T115A & 6 & 5 & 4 & 8 & 11 & 8 & 10 & 1 & 15 & 2 & 35 \\
\hline C116A & 0 & 6 & -2 & 10 & 0 & 2 & 1 & 3 & -2 & 3 & 2 \\
\hline A117S & 93 & 10 & 85 & 7 & 73 & 3 & 82 & 0 & 76 & 37 & 104 \\
\hline M118A & 63 & 6 & 53 & 3 & 39 & 8 & 42 & 1 & 85 & 1 & 64 \\
\hline F119A & 0 & 1 & -7 & 6 & 1 & 2 & 0 & 1 & -2 & 3 & 2 \\
\hline R120A & 127 & 50 & 85 & 6 & & & & & 97 & 19 & 136 \\
\hline K123A & 88 & 5 & 67 & 83 & & & & & 82 & 10 & 77 \\
\hline N124A & 110 & 54 & 210 & 61 & 139 & 39 & 131 & 0 & 116 & 62 & 153 \\
\hline M125A & 60 & 11 & 59 & 17 & 45 & 11 & 47 & 10 & 78 & 5 & 71 \\
\hline E126A & 100 & 29 & 84 & 6 & & & & & 58 & 20 & 101 \\
\hline G127A & 51 & 13 & 13 & 6 & 17 & 10 & 20 & 6 & 48 & 14 & 41 \\
\hline K128A & 94 & 16 & 68 & 7 & 54 & 9 & 63 & 14 & 60 & 16 & 84 \\
\hline V129A & 54 & 3 & 75 & 22 & 60 & 16 & 68 & 9 & 77 & 37 & 72 \\
\hline V130A & 49 & 6 & 17 & 5 & 21 & 9 & 30 & 8 & 48 & 6 & 50 \\
\hline Q131A & 110 & 9 & 113 & 26 & 96 & 3 & 88 & 4 & 139 & 86 & 132 \\
\hline P132A & 113 & 37 & 118 & 20 & 74 & 14 & 84 & 15 & 87 & 15 & 98 \\
\hline E133A & 89 & 14 & 69 & 11 & 79 & 3 & 74 & 32 & 92 & 37 & 106 \\
\hline N134A & 101 & 61 & 68 & 7 & 59 & 2 & 65 & 16 & 85 & 40 & 97 \\
\hline L135A & 48 & 30 & 25 & 2 & 25 & 11 & 24 & 12 & 19 & 4 & 52 \\
\hline E136A & 81 & 24 & 37 & 6 & 48 & 19 & 51 & 20 & 39 & 8 & 57 \\
\hline Y137A & 10 & 0 & 3 & 8 & 15 & 5 & 15 & 2 & 10 & 7 & 30 \\
\hline T138A & 21 & 1 & 15 & 0 & 18 & 9 & 19 & 4 & 20 & 4 & 37 \\
\hline I139A & 12 & 5 & 7 & 9 & 7 & 5 & 9 & 0 & 11 & 6 & 18 \\
\hline V140A & 100 & 32 & 159 & 51 & 101 & 18 & 112 & 7 & 143 & 34 & 118 \\
\hline I141A & 49 & 2 & 33 & 16 & 36 & 9 & 37 & 12 & 61 & 31 & 52 \\
\hline
\end{tabular}



aCC-BY-NC 4.0 International license.

\begin{tabular}{|c|c|c|c|c|c|c|c|c|c|c|c|c|}
\hline T142A & 75 & 15 & 83 & 35 & 62 & 1 & 73 & 13 & 76 & 22 & 87 & 5 \\
\hline P143A & 47 & 10 & 66 & 21 & 51 & 18 & 51 & 15 & 56 & 5 & 75 & 15 \\
\hline $\mathrm{H} 144 \mathrm{~A}$ & 17 & 9 & 39 & 33 & & & & & 29 & 6 & 54 & 6 \\
\hline S145A & 11 & 2 & 82 & 1 & 69 & 35 & 65 & 8 & 67 & 23 & 91 & 4 \\
\hline G146A & -3 & 1 & 59 & 9 & 51 & 7 & 44 & 8 & 19 & 3 & 83 & 0 \\
\hline E147A & 115 & 36 & 125 & 5 & 84 & 12 & 81 & 15 & 108 & 10 & 113 & 5 \\
\hline E148A & 86 & 25 & 132 & 51 & 75 & 18 & 77 & 2 & 88 & 4 & 98 & 16 \\
\hline H149A & 12 & 10 & 107 & 1 & 84 & 47 & 74 & 6 & 69 & 27 & 115 & 1 \\
\hline A150S & 121 & 39 & 125 & 15 & 101 & 23 & 89 & 2 & 129 & 25 & 107 & 7 \\
\hline V151A & 5 & 1 & 96 & 5 & 61 & 7 & 56 & 13 & 43 & 1 & 96 & 2 \\
\hline G152A & -3 & 1 & 59 & 1 & 52 & 17 & 54 & 8 & 24 & 11 & 89 & 2 \\
\hline N153A & 0 & 9 & 67 & 20 & 48 & 9 & 53 & 19 & 61 & 15 & 64 & 9 \\
\hline D154A & 91 & 36 & 120 & 5 & 95 & 17 & 108 & 11 & 80 & 6 & 111 & 8 \\
\hline T155A & -5 & 1 & 43 & 5 & 53 & 11 & 50 & 7 & 81 & 3 & 63 & 6 \\
\hline G156A & 98 & 63 & 99 & 7 & & & & & 79 & 2 & 112 & 3 \\
\hline K157A & 140 & 1 & 106 & 7 & 83 & 5 & 93 & 8 & 116 & 31 & 113 & 6 \\
\hline H158A & 55 & 2 & 86 & 4 & 71 & 3 & 69 & 4 & 136 & 12 & 106 & 7 \\
\hline G159A & 54 & 18 & 150 & 7 & 79 & 2 & 94 & 4 & 80 & 18 & 105 & 17 \\
\hline K160A & 131 & 9 & 162 & 2 & 103 & 18 & 106 & 2 & 67 & 3 & 130 & 8 \\
\hline E161A & 96 & 35 & 85 & 3 & 85 & 28 & 80 & 1 & 136 & 14 & 106 & 7 \\
\hline I162A & 35 & 17 & 22 & 18 & 26 & 13 & 30 & 8 & 51 & 8 & 49 & 4 \\
\hline K163A & 45 & 37 & 38 & 20 & 36 & 13 & 48 & 3 & 65 & 6 & 58 & 3 \\
\hline I164A & 6 & 1 & 3 & 11 & 4 & 3 & 7 & 3 & 1 & 3 & 18 & 2 \\
\hline T165A & 62 & 11 & 56 & 2 & 47 & 21 & 47 & 11 & 51 & 8 & 73 & 5 \\
\hline P166A & 136 & 83 & 177 & 15 & 94 & 16 & 106 & 29 & 116 & 31 & 129 & 13 \\
\hline Q167A & 138 & 76 & 129 & 15 & 77 & 35 & 90 & 14 & 88 & 10 & 97 & 4 \\
\hline S168A & 96 & 29 & 127 & 21 & 82 & 33 & 81 & 25 & 131 & 67 & 102 & 12 \\
\hline S169A & 109 & 45 & 111 & 3 & & & & & 70 & 63 & 121 & 9 \\
\hline I170A & 104 & 47 & 103 & 32 & 82 & 17 & 83 & 32 & 118 & 45 & 100 & 9 \\
\hline T171A & 114 & 30 & 142 & 36 & 101 & 32 & 103 & 15 & 150 & 49 & 144 & 1 \\
\hline E172A & 94 & 59 & 77 & 33 & 65 & 13 & 69 & 20 & 72 & 37 & 91 & 11 \\
\hline A173S & 57 & 28 & 50 & 16 & 47 & 13 & 52 & 9 & 69 & 27 & 70 & 3 \\
\hline $\mathrm{E} 174 \mathrm{~A}$ & 94 & 3 & 103 & 14 & 76 & 29 & 64 & 18 & 123 & 12 & 91 & 8 \\
\hline L175A & 0 & 1 & -3 & 7 & 2 & 2 & 5 & 3 & -1 & 3 & 14 & 0 \\
\hline T176A & 120 & 55 & 125 & 44 & 95 & 16 & 83 & 13 & 112 & 17 & 120 & 15 \\
\hline G177A & 25 & 22 & 23 & 6 & 28 & 5 & 30 & 6 & 30 & 6 & 50 & 1 \\
\hline Y178A & 12 & 1 & 9 & 7 & 16 & 3 & 15 & 5 & 24 & 5 & 35 & 5 \\
\hline G179A & 20 & 1 & 23 & 12 & & & & & 6 & 7 & 33 & 0 \\
\hline T180A & 116 & 22 & 82 & 9 & 70 & 17 & 83 & 15 & 68 & 33 & 99 & 4 \\
\hline V181A & 71 & 44 & 32 & 22 & 50 & 13 & 55 & 3 & 61 & 9 & 59 & 2 \\
\hline T182A & 117 & 26 & 119 & 36 & 82 & 33 & 92 & 27 & 120 & 7 & 119 & 10 \\
\hline M183A & 36 & 19 & 32 & 3 & 39 & 12 & 45 & 6 & 83 & 10 & 54 & 5 \\
\hline E184A & 88 & 26 & 102 & 29 & 81 & 15 & 63 & 23 & 109 & 16 & 84 & 9 \\
\hline C185A & 6 & 7 & -3 & 3 & 1 & 2 & 2 & 0 & -4 & 0 & 6 & 1 \\
\hline S186A & 63 & 17 & 109 & 2 & 74 & 17 & 83 & 22 & 109 & 46 & 104 & 4 \\
\hline P187A & 91 & 46 & 121 & 33 & 97 & 24 & 87 & 21 & 134 & 8 & 101 & 4 \\
\hline R188A & 86 & 21 & 111 & 56 & 94 & 27 & 99 & 26 & 112 & 38 & 112 & 12 \\
\hline T189A & 74 & 23 & 136 & 22 & 95 & 17 & 91 & 19 & 111 & 36 & 111 & 3 \\
\hline
\end{tabular}


bioRxiv preprint doi: https://doi.org/10.1101/790642; this version posted October 2, 2019. The copyright holder for this preprint (which was not certified by peer review) is the author/funder, who has granted bioRxiv a license to display the preprint in perpetuity. It is made available under aCC-BY-NC 4.0 International license.

\begin{tabular}{|c|c|c|c|c|c|c|c|c|c|c|c|c|}
\hline G190A & 78 & 0 & 123 & 6 & 87 & 34 & 98 & 20 & 129 & 5 & 120 & 0 \\
\hline L191A & 103 & 5 & 91 & 30 & & & & & 77 & 5 & 81 & 16 \\
\hline D192A & 44 & 1 & 37 & 12 & 35 & 5 & 40 & 14 & 43 & 15 & 67 & 8 \\
\hline F193A & 67 & 0 & 54 & 6 & 52 & 10 & 56 & 23 & 91 & 26 & 75 & 20 \\
\hline N194A & 93 & 5 & 97 & 36 & 91 & 31 & 80 & 15 & 108 & 22 & 93 & 1 \\
\hline E195A & 88 & 45 & 61 & & & & & & 39 & 7 & 65 & 15 \\
\hline M196A & 100 & 24 & 76 & 35 & 57 & 25 & 55 & 14 & 51 & 36 & 91 & 11 \\
\hline V197A & 20 & 22 & 7 & 1 & 11 & 5 & 16 & 1 & 19 & 4 & 44 & 5 \\
\hline L198A & 67 & 21 & 123 & 40 & 134 & 26 & 121 & 12 & 174 & 54 & 141 & 12 \\
\hline L199A & 73 & 16 & 76 & 4 & 44 & 7 & 48 & 15 & 72 & 2 & 76 & 14 \\
\hline Q200A & 61 & 22 & 55 & 6 & 47 & 14 & 50 & 16 & 87 & 7 & 81 & 13 \\
\hline M201A & 47 & 19 & 38 & 10 & 24 & 5 & 28 & 8 & 58 & 15 & 55 & 11 \\
\hline E202A & 79 & 13 & 121 & 2 & 91 & 18 & 81 & 1 & 87 & 31 & 97 & 1 \\
\hline N203A & 53 & 11 & 37 & 10 & 40 & 1 & 43 & 9 & 68 & 3 & 60 & 10 \\
\hline K204A & 96 & 10 & 20 & 4 & 43 & 14 & 46 & 11 & 100 & 8 & 63 & 0 \\
\hline A205S & 96 & 3 & 74 & 12 & & & & & 81 & 9 & 92 & 38 \\
\hline W206A & 37 & 12 & -3 & 6 & 15 & 5 & 19 & 5 & 46 & 17 & 34 & 12 \\
\hline L207A & 93 & 52 & 98 & 11 & 76 & 15 & 74 & 23 & 86 & 44 & 100 & 17 \\
\hline V208A & 37 & 15 & 22 & 26 & 32 & 14 & 27 & 7 & 35 & 1 & 45 & 2 \\
\hline H209A & 91 & 5 & 90 & 35 & 79 & 16 & 77 & 12 & 96 & 18 & 96 & 10 \\
\hline R210A & 42 & 3 & 39 & 4 & 31 & 7 & 28 & 6 & 26 & 3 & 52 & 9 \\
\hline Q211A & 87 & 21 & 71 & 11 & 67 & 5 & 81 & 15 & 117 & 33 & 96 & 1 \\
\hline W212A & 25 & 4 & -2 & 2 & 27 & 6 & 35 & 11 & 58 & 4 & 48 & 7 \\
\hline F213A & 16 & 2 & 1 & 9 & 8 & 3 & 9 & 3 & 24 & 1 & 30 & 5 \\
\hline L214A & 58 & 3 & 4 & & & & & & 44 & 9 & 22 & 6 \\
\hline D215A & 34 & 66 & 30 & 17 & & & & & 64 & 12 & 62 & 13 \\
\hline L216A & -3 & 0 & -1 & 16 & -1 & 3 & 1 & 0 & 3 & 9 & 5 & 1 \\
\hline P217A & 105 & 20 & 154 & 10 & 81 & 13 & 96 & 17 & 69 & 51 & 83 & 25 \\
\hline L218A & 1 & 4 & -1 & 3 & & & & & -12 & 8 & 1 & 1 \\
\hline P219A & 5 & 2 & 11 & 19 & 2 & 7 & 1 & 0 & -2 & 4 & 13 & 1 \\
\hline W220A & 7 & 2 & -2 & 7 & 2 & 3 & 2 & 0 & 1 & 4 & 11 & 2 \\
\hline L221A & 80 & 8 & 84 & 6 & 67 & 16 & 51 & 48 & 77 & 48 & 93 & 4 \\
\hline P222A & 47 & 89 & 123 & 70 & & & & & 80 & 3 & 84 & 10 \\
\hline G223A & 75 & 10 & 53 & 12 & 70 & 8 & 76 & 5 & 55 & 4 & 86 & 11 \\
\hline A224S & 85 & 7 & 167 & 13 & 121 & 20 & 109 & 7 & 106 & 58 & 112 & 3 \\
\hline D225A & 50 & 12 & 67 & 8 & 73 & 22 & 73 & 22 & 67 & 10 & 80 & 19 \\
\hline T226A & 93 & 26 & 110 & 47 & & & & & 116 & 22 & 88 & 16 \\
\hline Q227A & 90 & 59 & 94 & 2 & 90 & 27 & 94 & 20 & 92 & 61 & 107 & 6 \\
\hline G228A & 94 & 16 & 84 & 6 & 87 & 12 & 82 & 14 & 94 & 41 & 99 & 6 \\
\hline S229A & 84 & 75 & 113 & 10 & 95 & 37 & 95 & 19 & 77 & 28 & 138 & 21 \\
\hline N230A & 118 & 65 & 80 & 9 & & & & & 98 & 18 & 80 & 1 \\
\hline W231A & -1 & 2 & -1 & 1 & & & & & -5 & 8 & -1 & 2 \\
\hline I232A & 81 & 163 & 86 & 49 & & & & & 82 & 38 & 86 & 34 \\
\hline Q233A & 124 & 70 & 147 & 77 & & & & & 85 & 2 & 91 & 3 \\
\hline $\mathrm{K} 234 \mathrm{~A}$ & 117 & 107 & 87 & 8 & & & & & 63 & 12 & 88 & 19 \\
\hline E235A & 30 & 62 & 40 & 68 & & & & & 37 & 3 & 28 & 1 \\
\hline T236A & 96 & 31 & 96 & 22 & & & & & 73 & 19 & 90 & 53 \\
\hline
\end{tabular}



aCC-BY-NC 4.0 International license.

\begin{tabular}{|c|c|c|c|c|c|c|c|c|}
\hline L237A & 89 & 36 & 51 & 100 & 39 & 23 & 31 & 5 \\
\hline V238A & 24 & 48 & 31 & 51 & 51 & 3 & 38 & 10 \\
\hline T239A & 63 & 127 & 127 & 74 & 59 & 55 & 114 & 26 \\
\hline F240A & 34 & 70 & 45 & 71 & 29 & 21 & 20 & 3 \\
\hline $\mathrm{K} 241 \mathrm{~A}$ & 55 & 104 & 96 & 56 & 73 & 14 & 95 & 21 \\
\hline N242A & 2 & 6 & 139 & 19 & 85 & 28 & 107 & 4 \\
\hline P243A & 97 & 13 & 111 & 84 & 84 & 26 & 74 & 18 \\
\hline $\mathrm{H} 244 \mathrm{~A}$ & 68 & 12 & 82 & 11 & 80 & 8 & 60 & 2 \\
\hline A245S & 97 & 3 & 88 & 4 & 104 & 20 & 80 & 16 \\
\hline K246A & 56 & 22 & 98 & 39 & 108 & 27 & 118 & 46 \\
\hline K247A & 104 & 35 & 118 & 1 & 106 & 11 & 89 & 17 \\
\hline Q248A & 74 & 10 & 78 & 71 & 72 & 14 & 56 & 13 \\
\hline D249A & 84 & 36 & 74 & 36 & 63 & 21 & 83 & 11 \\
\hline V250A & 118 & 34 & 75 & 26 & 78 & 25 & 72 & 13 \\
\hline V251A & 130 & 33 & 119 & 39 & 110 & 43 & 100 & 18 \\
\hline V252A & 101 & 4 & 135 & 79 & 102 & 12 & 133 & 34 \\
\hline L253A & 114 & 3 & 85 & 19 & 57 & 7 & 91 & 19 \\
\hline G254A & 77 & 15 & 84 & 26 & 86 & 29 & 84 & 4 \\
\hline S255A & 54 & 24 & 16 & 12 & 41 & 1 & 43 & 16 \\
\hline Q256A & 89 & 22 & 6 & 9 & 60 & 45 & 71 & 10 \\
\hline E257A & 101 & 19 & 74 & 3 & 73 & 6 & 73 & 14 \\
\hline G258A & 54 & 17 & 92 & 38 & 55 & 0 & 90 & 19 \\
\hline A259S & 93 & 22 & 61 & 2 & 60 & 7 & 69 & 2 \\
\hline M260A & 18 & 7 & 46 & 84 & 6 & 11 & 15 & 8 \\
\hline $\mathrm{H} 261 \mathrm{~A}$ & 109 & 28 & 77 & 32 & 60 & 1 & 82 & 16 \\
\hline T262A & 61 & 97 & 98 & 49 & 141 & 3 & 108 & 37 \\
\hline A263S & 69 & 51 & 51 & 56 & 64 & 0 & 62 & 14 \\
\hline L264A & 40 & 1 & -3 & 1 & 21 & 16 & 25 & 10 \\
\hline T265A & 99 & 32 & 34 & 67 & 115 & 99 & 129 & 31 \\
\hline G266A & 70 & 25 & 3 & 4 & 97 & 1 & 82 & 3 \\
\hline A267S & 89 & 2 & 72 & 46 & 94 & 13 & 84 & 31 \\
\hline T268A & 106 & 18 & 80 & 47 & 82 & 6 & 84 & 24 \\
\hline E269A & 64 & 5 & 76 & 47 & 83 & 27 & 77 & 29 \\
\hline I270A & 116 & 42 & 64 & 27 & 95 & 3 & 94 & 13 \\
\hline Q271A & 98 & 70 & 75 & 22 & 130 & 22 & 92 & 27 \\
\hline M272A & 73 & 17 & 65 & 21 & 146 & 18 & 97 & 29 \\
\hline S273A & 112 & 10 & 99 & 18 & 87 & 27 & 100 & 32 \\
\hline S274A & 103 & 13 & 74 & 5 & 85 & 19 & 97 & 16 \\
\hline G275A & 135 & 20 & 66 & 35 & 90 & 0 & 57 & 8 \\
\hline N276A & 128 & 7 & 76 & 28 & 108 & 17 & 96 & 51 \\
\hline L277A & 56 & 46 & 97 & 10 & 111 & 90 & 127 & 11 \\
\hline L278A & 44 & 35 & 126 & 55 & 92 & 19 & 96 & 11 \\
\hline F279A & 28 & 15 & 76 & 31 & 86 & 78 & 70 & 19 \\
\hline T280A & 52 & 31 & 113 & 37 & 130 & 19 & 127 & 19 \\
\hline G281A & 8 & 0 & 83 & 100 & 43 & 36 & 48 & 20 \\
\hline $\mathrm{H} 282 \mathrm{~A}$ & 104 & 15 & 128 & 54 & 142 & 4 & 130 & 32 \\
\hline L283A & 36 & 18 & 52 & 48 & 46 & 1 & 69 & 23 \\
\hline K284A & 77 & 4 & 80 & 5 & 58 & 33 & 84 & 21 \\
\hline
\end{tabular}



aCC-BY-NC 4.0 International license.

\begin{tabular}{|c|c|c|c|c|c|c|c|c|}
\hline C285A & 3 & 8 & 37 & 80 & 30 & 58 & 4 & 2 \\
\hline R286A & 68 & 30 & 47 & 56 & 54 & 2 & 37 & 1 \\
\hline L287A & 124 & 8 & 59 & 2 & 102 & 8 & 98 & 12 \\
\hline R288A & 73 & 27 & 62 & 17 & 94 & 14 & 60 & 29 \\
\hline M289A & 23 & 1 & 18 & 13 & 12 & 4 & 29 & 3 \\
\hline D290A & 64 & 1 & 50 & 30 & 49 & 18 & 53 & 14 \\
\hline $\mathrm{K} 291 \mathrm{~A}$ & 56 & 28 & 80 & 29 & 71 & 1 & 65 & 19 \\
\hline L292A & 19 & 20 & 50 & 31 & 25 & 1 & 50 & 20 \\
\hline Q293A & 106 & 3 & 70 & 45 & 62 & 9 & 94 & 31 \\
\hline L294A & 83 & 3 & 76 & 2 & 104 & 6 & 79 & 23 \\
\hline K295A & 92 & 35 & 85 & 28 & 65 & 6 & 76 & 12 \\
\hline G296A & 8 & 4 & 63 & 37 & 4 & 18 & 48 & 6 \\
\hline M297A & 121 & 66 & 71 & 14 & 74 & 1 & 122 & 16 \\
\hline S298A & 78 & 25 & 74 & 34 & 104 & 44 & 95 & 19 \\
\hline Y299A & 60 & 10 & 72 & 39 & 54 & 5 & 62 & 10 \\
\hline S300A & 91 & 45 & 108 & 77 & 111 & 4 & 93 & 25 \\
\hline M301A & 89 & 24 & 103 & 62 & 115 & 17 & 94 & 28 \\
\hline C302A & 3 & 2 & 41 & 84 & -4 & 14 & 5 & 2 \\
\hline ТЗ303А & 70 & 34 & 99 & 31 & 102 & 37 & 82 & 28 \\
\hline G304A & 19 & 8 & 54 & 95 & 22 & 13 & 26 & 2 \\
\hline K305A & 113 & 0 & 83 & 5 & 121 & 33 & 80 & 14 \\
\hline F306A & 4 & 2 & 40 & 82 & -6 & & 8 & 3 \\
\hline K307A & 86 & 1 & 76 & 24 & 104 & 16 & 72 & 31 \\
\hline V308A & 31 & 42 & 93 & 87 & 53 & 52 & 78 & 11 \\
\hline V309A & 47 & 89 & 52 & 7 & 57 & 10 & 75 & 29 \\
\hline K310A & 7 & 1 & 68 & 41 & -5 & 11 & 66 & 21 \\
\hline E311A & 43 & 85 & 87 & 30 & 77 & 3 & 85 & 1 \\
\hline I312A & 104 & 6 & 65 & 45 & 78 & 38 & 63 & 24 \\
\hline A313S & 48 & 92 & 78 & 31 & 54 & 16 & 66 & 6 \\
\hline E314A & 82 & 21 & 54 & 13 & 86 & 41 & 75 & 17 \\
\hline T315A & 0 & 1 & 18 & & 23 & 21 & 40 & 1 \\
\hline Q316A & 27 & 55 & 152 & 92 & 40 & 9 & 71 & 18 \\
\hline H317A & 25 & 48 & 85 & 33 & 100 & 38 & 80 & 18 \\
\hline G318A & 41 & 30 & 58 & 33 & 48 & 7 & 59 & 5 \\
\hline T319A & -2 & 4 & 91 & 131 & 0 & 6 & 35 & 17 \\
\hline I320A & 40 & 9 & 46 & 56 & 28 & 0 & 35 & 1 \\
\hline V321A & 22 & 14 & 110 & 147 & 64 & 10 & 49 & 4 \\
\hline I322A & 60 & 0 & 109 & 142 & 64 & 16 & 58 & 5 \\
\hline R323A & 69 & 21 & 86 & 1 & 75 & 25 & 82 & 2 \\
\hline V324A & 37 & 32 & 71 & 94 & 28 & 6 & 49 & 11 \\
\hline Q325A & 133 & 55 & 103 & 0 & 91 & 11 & 102 & 14 \\
\hline Y326A & 7 & 3 & 41 & 73 & -3 & 6 & 12 & 2 \\
\hline E327A & 127 & 48 & 78 & 2 & 88 & 19 & 76 & 22 \\
\hline G328A & 55 & 17 & 65 & 55 & 35 & 4 & 56 & 18 \\
\hline D329A & 153 & 81 & 121 & 35 & 79 & 23 & 99 & 3 \\
\hline G330A & 104 & 27 & 78 & 39 & 59 & 3 & 90 & 9 \\
\hline S331A & 141 & 21 & 114 & 32 & 85 & 33 & 122 & 6 \\
\hline P332A & 36 & 4 & 30 & 30 & 10 & 0 & 33 & 3 \\
\hline
\end{tabular}



aCC-BY-NC 4.0 International license.

\begin{tabular}{|c|c|c|c|c|c|c|c|c|}
\hline C333A & 2 & 1 & 10 & 11 & 3 & 3 & 5 & 3 \\
\hline K334A & 68 & 18 & 69 & 25 & 49 & 4 & 63 & 14 \\
\hline I335A & 9 & 0 & 34 & 66 & 16 & 13 & 12 & 0 \\
\hline P336A & 52 & 35 & 88 & 106 & 31 & 8 & 50 & 10 \\
\hline F337A & 62 & 7 & 64 & 74 & 35 & 8 & 38 & 13 \\
\hline E338A & 136 & 32 & 107 & 12 & 114 & 36 & 105 & 1 \\
\hline I339A & 10 & 5 & 47 & 90 & -5 & 7 & 12 & 2 \\
\hline M340A & 75 & 13 & 44 & 11 & 57 & 14 & 69 & 26 \\
\hline D341A & 86 & 5 & 80 & 45 & 67 & 21 & 80 & 7 \\
\hline L342A & 119 & 44 & 106 & 34 & 103 & 36 & 121 & 26 \\
\hline E343A & 96 & 33 & 96 & 35 & 82 & 40 & 97 & 7 \\
\hline K344A & 115 & 23 & 85 & 21 & 42 & 7 & 87 & 17 \\
\hline R345A & 105 & 38 & 86 & 33 & 64 & 2 & 78 & 21 \\
\hline $\mathrm{H} 346 \mathrm{~A}$ & 99 & 18 & 49 & 18 & 101 & 13 & 89 & 9 \\
\hline V347A & 131 & 24 & 97 & 6 & 94 & 4 & 106 & 5 \\
\hline L348A & 107 & 21 & 94 & 35 & 77 & 4 & 93 & 6 \\
\hline G349A & 46 & 26 & 68 & 18 & 22 & 21 & 45 & 2 \\
\hline R350A & 35 & 12 & 61 & 48 & 30 & 24 & 57 & 9 \\
\hline L351A & 86 & 16 & 52 & 4 & 47 & 26 & 73 & 13 \\
\hline I352A & 15 & 12 & 32 & 22 & -5 & 17 & 39 & 8 \\
\hline T353A & 29 & 12 & 25 & 33 & 12 & 1 & 38 & 11 \\
\hline V354A & 104 & 61 & 143 & 44 & 77 & 42 & 119 & 27 \\
\hline N355A & 104 & 31 & 83 & 19 & 53 & 23 & 78 & 20 \\
\hline P356A & 25 & 3 & 68 & 36 & 41 & 22 & 54 & 14 \\
\hline I357A & 45 & 5 & 67 & 23 & 29 & 5 & 66 & 14 \\
\hline V358A & 58 & 63 & 127 & 99 & 103 & 34 & 55 & 7 \\
\hline T359A & 99 & 37 & 71 & 8 & 113 & 7 & 91 & 34 \\
\hline E360A & 97 & 24 & 107 & 41 & 101 & 76 & 111 & 31 \\
\hline K361A & 94 & 6 & 81 & 38 & 107 & 39 & 92 & 32 \\
\hline D362A & 96 & 12 & 77 & 34 & 94 & 0 & 113 & 30 \\
\hline S363A & 112 & 26 & 143 & 91 & 97 & 16 & 101 & 27 \\
\hline P364A & 95 & 13 & 116 & 63 & 97 & 5 & 96 & 39 \\
\hline V365A & 56 & 9 & 51 & 42 & 43 & 3 & 53 & 2 \\
\hline N366A & 19 & 12 & 66 & 14 & 79 & 14 & 95 & 22 \\
\hline I367A & 7 & 3 & 1 & 3 & 2 & 6 & 8 & 3 \\
\hline E368A & 5 & 1 & 47 & 70 & -7 & 5 & 24 & 4 \\
\hline A369S & 78 & 16 & 68 & 54 & 41 & 17 & 53 & 10 \\
\hline E370A & 117 & 16 & 53 & 40 & 101 & 46 & 68 & 27 \\
\hline P371A & 52 & 27 & 43 & 17 & 72 & 6 & 70 & 0 \\
\hline P372A & 57 & 40 & 73 & 33 & 54 & 4 & 56 & 10 \\
\hline F373A & 88 & 28 & 94 & 0 & 83 & 35 & 112 & 39 \\
\hline G374A & 49 & 16 & 66 & 48 & 42 & 5 & 69 & 23 \\
\hline D375A & 130 & 28 & 94 & 52 & 125 & 1 & 125 & 46 \\
\hline S376A & 55 & 14 & 69 & 29 & 48 & 13 & 75 & 9 \\
\hline Y377A & 113 & 12 & 84 & 2 & 74 & 29 & 105 & 10 \\
\hline I378A & 31 & 22 & 95 & 163 & 42 & 22 & 32 & 10 \\
\hline I379A & 66 & 34 & 62 & 24 & 68 & 25 & 82 & 10 \\
\hline $\mathrm{I} 380 \mathrm{~A}$ & 2 & 1 & 0 & 4 & -5 & 8 & 7 & 3 \\
\hline
\end{tabular}



aCC-BY-NC 4.0 International license.

\begin{tabular}{|c|c|c|c|c|c|c|c|c|}
\hline G381A & 2 & 2 & 32 & 65 & 3 & 6 & 4 & 0 \\
\hline V382A & 102 & 12 & 157 & 55 & 107 & 33 & 90 & 13 \\
\hline E383A & 106 & 7 & 61 & 32 & 82 & 28 & 96 & 20 \\
\hline P384A & 52 & 29 & 45 & 48 & 48 & 0 & 43 & 14 \\
\hline G385A & 128 & 6 & 78 & 45 & 72 & 27 & 88 & 1 \\
\hline Q386A & 127 & 6 & 89 & 13 & 101 & 39 & 99 & 36 \\
\hline L387A & 35 & 2 & 18 & 14 & 20 & 12 & 44 & 7 \\
\hline K388A & 78 & 39 & 92 & 0 & 105 & 40 & 99 & 40 \\
\hline L389A & 42 & 10 & 23 & 15 & 31 & 14 & 34 & 6 \\
\hline N390A & 111 & 75 & 94 & 16 & 114 & 69 & 106 & 27 \\
\hline W391A & 26 & 16 & 42 & 71 & 22 & 18 & 37 & 14 \\
\hline F392A & 104 & 10 & 75 & 27 & 72 & 2 & 75 & 28 \\
\hline K393A & 86 & 11 & 67 & 23 & 28 & 3 & 54 & 7 \\
\hline K394A & 124 & 5 & 78 & 31 & 75 & 58 & 98 & 33 \\
\hline G395A & 109 & 56 & 129 & 50 & 87 & 42 & 79 & 7 \\
\hline S396A & 119 & 36 & 86 & 41 & 113 & 1 & 106 & 8 \\
\hline S397A & 131 & 37 & 51 & 2 & 76 & 9 & 108 & 40 \\
\hline I398A & 108 & 15 & 85 & 62 & 107 & 1 & 114 & 28 \\
\hline G399A & 120 & 16 & 97 & 53 & 118 & 81 & 91 & 43 \\
\hline Q400A & 139 & 4 & 105 & 79 & 82 & 19 & 95 & 5 \\
\hline M401A & 130 & 7 & 122 & 83 & 88 & 40 & 118 & 25 \\
\hline $\mathrm{F} 402 \mathrm{~A}$ & 111 & 40 & 119 & 65 & 155 & 25 & 97 & 9 \\
\hline E403A & 100 & 29 & 79 & 14 & 95 & 32 & 102 & 30 \\
\hline T404A & 101 & 24 & 81 & 16 & 139 & 6 & 107 & 34 \\
\hline T405A & 103 & 61 & 79 & 1 & 116 & 96 & 111 & 24 \\
\hline M406A & 113 & 28 & 96 & 21 & 99 & 8 & 96 & 44 \\
\hline R407A & 117 & 6 & 103 & 19 & 58 & 37 & 77 & 1 \\
\hline G408A & 115 & 22 & 88 & 24 & 86 & 2 & 115 & 21 \\
\hline A409S & 123 & 12 & 59 & 33 & 124 & 37 & 102 & 20 \\
\hline K410A & 97 & 12 & 62 & 71 & 110 & 4 & 106 & 15 \\
\hline $\mathrm{R} 411 \mathrm{~A}$ & 105 & 19 & 143 & 65 & 63 & 32 & 105 & 39 \\
\hline $\mathrm{M} 412 \mathrm{~A}$ & 109 & 28 & 129 & 61 & 99 & 38 & 98 & 41 \\
\hline A413S & 104 & 15 & 133 & 66 & 84 & 15 & 110 & 6 \\
\hline $1414 \mathrm{~A}$ & 136 & 33 & 130 & 17 & 105 & 3 & 92 & 34 \\
\hline L415A & 101 & 13 & 143 & 97 & 106 & 37 & 107 & 38 \\
\hline G416A & 108 & 34 & 156 & 143 & 121 & 38 & 88 & 4 \\
\hline D417A & 90 & 5 & 84 & 10 & 112 & 21 & 117 & 9 \\
\hline T418A & 102 & 45 & 86 & 6 & 82 & 6 & 103 & 18 \\
\hline A419S & 113 & 15 & 103 & 13 & 84 & 3 & 116 & 30 \\
\hline W420A & 111 & 37 & 86 & 41 & 71 & 3 & 110 & 8 \\
\hline $\mathrm{D} 421 \mathrm{~A}$ & 123 & 20 & 91 & 21 & 105 & 4 & 114 & 27 \\
\hline $\mathrm{F} 422 \mathrm{~A}$ & 107 & 7 & 87 & 8 & 111 & 24 & 88 & 18 \\
\hline G423A & 118 & 54 & 102 & 59 & 81 & 26 & 120 & 28 \\
\hline S424A & 141 & 95 & 97 & 37 & 73 & 34 & 109 & 5 \\
\hline L425A & 112 & 60 & 113 & 52 & 76 & 6 & 119 & 23 \\
\hline G426A & 120 & 69 & 111 & 24 & 74 & 46 & 118 & 18 \\
\hline G427A & 137 & 69 & 115 & 50 & 65 & 49 & 103 & 5 \\
\hline V428A & 116 & 54 & 86 & 7 & 112 & 0 & 87 & 2 \\
\hline
\end{tabular}



aCC-BY-NC 4.0 International license.

\begin{tabular}{|c|c|c|c|c|c|c|c|c|}
\hline F429A & 123 & 25 & 114 & 27 & 98 & 8 & 108 & 27 \\
\hline $\mathrm{T} 430 \mathrm{~A}$ & 118 & 62 & 91 & 7 & 78 & 10 & 89 & 11 \\
\hline S431A & 113 & 9 & 107 & 33 & 120 & 59 & 92 & 26 \\
\hline I432A & 126 & 7 & 79 & 0 & 119 & 23 & 95 & 13 \\
\hline G433A & 108 & 9 & 93 & 33 & 113 & 32 & 96 & 16 \\
\hline $\mathrm{K} 434 \mathrm{~A}$ & 134 & 42 & 84 & 8 & 115 & 8 & 95 & 27 \\
\hline A435S & 117 & 47 & 86 & 1 & 78 & 6 & 98 & 4 \\
\hline L436A & 122 & 55 & 123 & 28 & 135 & 12 & 119 & 15 \\
\hline $\mathrm{H} 437 \mathrm{~A}$ & 138 & 44 & 102 & 3 & 63 & 39 & 107 & 15 \\
\hline Q438A & 133 & 11 & 138 & 103 & 92 & 49 & 106 & 33 \\
\hline V439A & 96 & 0 & 92 & 4 & 82 & 7 & 106 & 34 \\
\hline F440A & 116 & 44 & 107 & 50 & 78 & 8 & 112 & 6 \\
\hline G441A & 141 & 71 & 84 & 27 & 77 & 8 & 123 & 15 \\
\hline A442S & 114 & 35 & 109 & 37 & 57 & 21 & 96 & 24 \\
\hline I443A & 110 & 15 & 99 & 7 & 114 & 24 & 105 & 11 \\
\hline Y444A & 109 & 4 & 97 & 39 & 82 & 7 & 88 & 7 \\
\hline G445A & 103 & 10 & 163 & 59 & 52 & 32 & 92 & 7 \\
\hline A446S & 134 & 8 & 91 & 8 & 104 & 50 & 94 & 20 \\
\hline A447S & 128 & 19 & 87 & 11 & 76 & 19 & 105 & 27 \\
\hline F448A & 113 & 60 & 125 & 62 & 85 & 31 & 108 & 9 \\
\hline S449A & 140 & 84 & 89 & 24 & 84 & 15 & 110 & 35 \\
\hline G450A & 82 & 21 & 80 & 14 & 92 & 25 & 95 & 29 \\
\hline V451A & 125 & 95 & 97 & 17 & 82 & 28 & 111 & 40 \\
\hline S452A & 90 & 14 & 94 & 4 & 67 & 26 & 99 & 25 \\
\hline W453A & 140 & 38 & 91 & 25 & 136 & 22 & 113 & 17 \\
\hline T454A & 93 & 41 & 65 & & 99 & 26 & 100 & 2 \\
\hline M455A & 117 & 19 & 107 & 31 & 109 & 15 & 109 & 34 \\
\hline $\mathrm{K} 456 \mathrm{~A}$ & 112 & 33 & 83 & 48 & 95 & 66 & 97 & 20 \\
\hline I457A & 112 & 17 & 75 & 25 & 128 & 1 & 106 & 15 \\
\hline L458A & 90 & 29 & 82 & 24 & 106 & 2 & 114 & 44 \\
\hline I459A & 109 & 5 & 135 & 72 & 91 & 15 & 111 & 3 \\
\hline G460A & 105 & 28 & 70 & 2 & 100 & 20 & 98 & 13 \\
\hline V461A & 104 & 44 & 146 & 92 & 112 & 37 & 116 & 37 \\
\hline I462A & 151 & 74 & 84 & 19 & 83 & 22 & 99 & 1 \\
\hline I463A & 129 & 64 & 67 & 17 & 129 & 24 & 109 & 28 \\
\hline T464A & 101 & 28 & 77 & 13 & 154 & 58 & 98 & 6 \\
\hline W465A & 92 & 6 & 79 & 3 & 80 & 11 & 119 & 24 \\
\hline I466A & 101 & 40 & 89 & 28 & 91 & 51 & 91 & 7 \\
\hline G467A & 117 & 3 & 68 & 32 & 142 & 8 & 82 & 16 \\
\hline M468A & 84 & 14 & 93 & 59 & 76 & 35 & 99 & 16 \\
\hline N469A & 104 & 2 & 63 & & 91 & 19 & 90 & 19 \\
\hline S470A & 69 & 58 & 141 & 79 & 81 & 42 & 89 & 27 \\
\hline $\mathrm{R} 471 \mathrm{~A}$ & 83 & 17 & 90 & 2 & 91 & 57 & 110 & 0 \\
\hline S472A & 83 & 8 & 97 & 14 & 99 & 9 & 120 & 22 \\
\hline T473A & 118 & 13 & 111 & 26 & 132 & 22 & 115 & 39 \\
\hline S474A & 94 & 2 & 74 & 18 & 77 & 5 & 112 & 38 \\
\hline L475A & 143 & 81 & 77 & 20 & 76 & 5 & 103 & 23 \\
\hline S476A & 113 & 15 & 141 & 79 & 78 & 16 & 106 & 41 \\
\hline
\end{tabular}


bioRxiv preprint doi: https://doi.org/10.1101/790642; this version posted October 2, 2019. The copyright holder for this preprint (which was not certified by peer review) is the author/funder, who has granted bioRxiv a license to display the preprint in perpetuity. It is made available under aCC-BY-NC 4.0 International license.

\begin{tabular}{|c|c|c|c|c|c|c|c|c|}
\hline V477A & 113 & 23 & 74 & 19 & 93 & 3 & 116 & 37 \\
\hline T478A & 148 & 14 & 69 & 29 & 90 & 3 & 115 & 11 \\
\hline L479A & 155 & 7 & 53 & 6 & 120 & 4 & 112 & 19 \\
\hline V480A & 126 & 24 & 82 & 27 & 108 & 76 & 92 & 14 \\
\hline L481A & 139 & 38 & 103 & 73 & 94 & 15 & 88 & 4 \\
\hline V482A & 134 & 33 & 121 & 85 & 88 & 4 & 100 & 2 \\
\hline G483A & 88 & 29 & 99 & 5 & 96 & 34 & 96 & 30 \\
\hline I484A & 87 & 66 & 87 & 18 & 114 & 46 & 111 & 21 \\
\hline V485A & 134 & 12 & 67 & 33 & 95 & 60 & 114 & 28 \\
\hline T486A & 111 & 32 & 98 & 26 & 115 & 9 & 104 & 36 \\
\hline L487A & 140 & 26 & 86 & 11 & 75 & 3 & 103 & 40 \\
\hline Y488A & 146 & 64 & 80 & 22 & 91 & 67 & 109 & 26 \\
\hline L489A & 111 & 30 & 119 & 49 & 74 & 23 & 92 & 3 \\
\hline G490A & 125 & 68 & 100 & 26 & 70 & 9 & 107 & 22 \\
\hline V491A & 106 & 43 & 62 & 2 & 79 & 17 & 112 & 15 \\
\hline M492A & 106 & 55 & 74 & 54 & 100 & 38 & 113 & 24 \\
\hline V493A & 130 & 57 & 108 & 91 & 92 & 3 & 91 & 9 \\
\hline Q494A & 97 & 54 & 116 & 59 & 87 & 15 & 97 & 11 \\
\hline A495S & 93 & 38 & 95 & 56 & 145 & 19 & 98 & 22 \\
\hline
\end{tabular}


Table S2. Summary of Ig sequences, clonal families and their corresponding mean SHM in unstimulated PBMCs vs. stimulated PBMCs from DENV-infected patient 013.

\begin{tabular}{|l|c|c|}
\hline & $\begin{array}{c}\text { Unstimulated } \\
\text { PBMCs }\end{array}$ & $\begin{array}{c}\text { Stimulated } \\
\text { PBMCs }\end{array}$ \\
\hline HC all unique reads & 162928 & 1245789 \\
HC sequences with UMI $\geq 2$ & 18588 & 146287 \\
HC clonal families & 11596 & 11407 \\
\hline IgM sequences & 15318 & 4684 \\
SHM, IgM sequences & $0.6 \%$ & $2.7 \%$ \\
IgG sequences & 2156 & 129636 \\
SHM, IgG sequences & $6.7 \%$ & $7.0 \%$ \\
IgA sequences & 1114 & 11967 \\
SHM, IgA sequences & $7.0 \%$ & $6.2 \%$ \\
\hline Unique clonal family threshold & $17.8 \%$ & $21.4 \%$ \\
IgM clonal families & 9794 & 2260 \\
SHM, IgM clonal families & $0.6 \%$ & $1.9 \%$ \\
IgG clonal families & 1243 & 5657 \\
SHM, IgG clonal families & $6.0 \%$ & $5.6 \%$ \\
IgA clonal families & 559 & 3490 \\
SHM, IgA clonal families & $6.9 \%$ & $6.3 \%$ \\
\hline
\end{tabular}


Table S3. Sequences from unstimulated PBMCs or stimulated PBMCs related to the clonal families of single cell plasmablasts with reactivity to dengue virus isolated from patient 013.

\begin{tabular}{|c|c|c|c|c|}
\hline \multirow{2}{*}{$\begin{array}{l}\text { Clonal family } \\
\text { (mAbs) }\end{array}$} & \multirow{2}{*}{ Germline } & \multirow{2}{*}{ Isotype } & \multicolumn{2}{|c|}{ Reads for all clonotypes } \\
\hline & & & Unstimulated PBMCs & Stimulated PBMCs \\
\hline \multirow{4}{*}{$\begin{array}{c}\text { CF10 } \\
(\mathrm{C} 1, \mathrm{~A} 7, \mathrm{I} 11, \mathrm{~L} 9, \mathrm{P} 2, \mathrm{G} 5)\end{array}$} & \multirow[t]{4}{*}{ IGHV3-30-3 } & total & 143 & 216292 \\
\hline & & $\operatorname{IgM}$ & 8 & 427 \\
\hline & & $\operatorname{IgG}$ & 112 & 199151 \\
\hline & & $\operatorname{Ig} \mathrm{A}$ & 23 & 16714 \\
\hline \multirow{4}{*}{$\begin{array}{c}\mathrm{CF} 5 \\
(\mathrm{C} 4, \mathrm{~J} 2, \mathrm{~N} 2)\end{array}$} & \multirow[t]{4}{*}{ IGHV1-69 } & total & 422 & 141308 \\
\hline & & $\operatorname{IgM}$ & 9 & 91 \\
\hline & & $\operatorname{IgG}$ & 413 & 140117 \\
\hline & & $\operatorname{IgA}$ & 0 & 1100 \\
\hline \multirow{4}{*}{$\begin{array}{c}\text { CF13 } \\
(\mathrm{N} 8, \mathrm{~F} 4)\end{array}$} & \multirow[t]{4}{*}{ IGHV4-34 } & total & 32 & 82814 \\
\hline & & $\operatorname{IgM}$ & 0 & 195 \\
\hline & & $\operatorname{IgG}$ & 32 & 76605 \\
\hline & & $\operatorname{Ig} \mathrm{A}$ & 0 & 6014 \\
\hline \multirow{4}{*}{$\begin{array}{c}\text { CF7 } \\
(\mathrm{J} 8, \mathrm{~J} 9)\end{array}$} & \multirow[t]{4}{*}{ IGHV1-69 } & total & 579 & 43179 \\
\hline & & $\operatorname{IgM}$ & 10 & 98 \\
\hline & & $\operatorname{IgG}$ & 568 & 42315 \\
\hline & & $\operatorname{IgA}$ & 1 & 764 \\
\hline \multirow{4}{*}{$\begin{array}{c}\text { CF9 } \\
(\mathrm{K} 11, \mathrm{~L} 3, \mathrm{M} 4, \mathrm{M} 11, \mathrm{O} 4)\end{array}$} & \multirow[t]{4}{*}{ IGHV1-69 } & total & 673 & 35793 \\
\hline & & $\operatorname{IgM}$ & 12 & 103 \\
\hline & & $\operatorname{IgG}$ & 656 & 34444 \\
\hline & & $\operatorname{Ig} \mathrm{A}$ & 5 & 1246 \\
\hline CF8 & IGHV1-69 & total & 10 & 7349 \\
\hline$\left(\mathrm{J} 3,403 \_\mathrm{P} 4\right)$ & & $\operatorname{IgM}$ & 0 & 16 \\
\hline
\end{tabular}




\begin{tabular}{|c|c|c|c|c|}
\hline & & $\begin{array}{l}\mathrm{IgG} \\
\mathrm{IgA}\end{array}$ & $\begin{array}{c}10 \\
0 \\
\end{array}$ & $\begin{array}{c}7001 \\
332 \\
\end{array}$ \\
\hline $\begin{array}{c}\text { CF3 } \\
\left(405 \_ \text {P4, I13) }\right.\end{array}$ & IGHV1-18 & $\begin{array}{l}\text { total } \\
\text { IgM } \\
\text { IgG } \\
\text { IgA }\end{array}$ & $\begin{array}{c}10 \\
1 \\
9 \\
0\end{array}$ & $\begin{array}{c}2993 \\
6 \\
2899 \\
88\end{array}$ \\
\hline $\begin{array}{c}\text { CF1 } \\
(\mathrm{B} 10, \mathrm{M} 1, \mathrm{D} 8)\end{array}$ & IGHV4-39 & $\begin{array}{l}\text { total } \\
\text { IgM } \\
\text { IgG } \\
\text { IgA }\end{array}$ & $\begin{array}{l}4 \\
1 \\
3 \\
0\end{array}$ & $\begin{array}{c}1087 \\
11 \\
1049 \\
27\end{array}$ \\
\hline $\begin{array}{c}\text { CF2 } \\
(\mathrm{H} 3, \mathrm{M} 6)\end{array}$ & IGHV1-69 & $\begin{array}{l}\text { total } \\
\text { IgM } \\
\text { IgG } \\
\text { IgA }\end{array}$ & $\begin{array}{l}0 \\
0 \\
0 \\
0\end{array}$ & $\begin{array}{c}1087 \\
7 \\
1066 \\
14\end{array}$ \\
\hline $\begin{array}{c}\text { CF11 } \\
(\mathrm{E} 9, \mathrm{I})\end{array}$ & IGHV3-30-3 & $\begin{array}{l}\text { total } \\
\text { IgM } \\
\text { IgG } \\
\text { IgA }\end{array}$ & $\begin{array}{l}0 \\
0 \\
0 \\
0\end{array}$ & $\begin{array}{c}19 \\
0 \\
19 \\
0 \\
\end{array}$ \\
\hline
\end{tabular}


Figure S1

\begin{tabular}{|c|c|c|c|c|c|c|c|c|c|c|c|c|c|c|c|c|c|}
\hline \multirow{2}{*}{ Patient ID } & \multirow{2}{*}{ Clonal family ID } & \multirow{2}{*}{ mAb name } & \multicolumn{3}{|c|}{ VH } & \multicolumn{3}{|c|}{$\overline{\mathrm{VL}}$} & \multirow{2}{*}{$\begin{array}{c}\text { Crude [lgG] } \\
\text { (ug/mL) }\end{array}$} & \multicolumn{2}{|c|}{ Fold change in binding } & \multicolumn{6}{|c|}{ \% Neutralization } \\
\hline & & & Gene & $\%$ nt mutation & CDR3 aa length & Gene & $\%$ nt mutation & CDR3 aa length & & DENV2 rE & DENV2 RVP & DENV1 & DENV2 & DENV3 & DENV4 & ZIKV & WNV \\
\hline 020 & CF1 & B10 & $4-39$ & 2.68 & 10 & $1-9$ & 2.47 & 9 & 3.21 & 6 & & 65 & 43 & 64 & 69 & 38 & 11 \\
\hline 013 & & M1 & $4-39$ & 10.77 & 10 & $1-9$ & 1.06 & $\frac{5}{9}$ & 4.77 & 4 & 13 & 73 & 77 & 65 & 84 & 33 & 47 \\
\hline 020 & & D8 & $4-39$ & 5.30 & 10 & $1-9$ & 2.13 & 9 & 1.77 & 2 & 15 & 48 & 41 & 55 & 42 & 28 & 44 \\
\hline 013 & CF2 & M6 & $1-69$ & 2.72 & 15 & $1-40$ & 4.73 & 11 & 4.88 & $\frac{2}{2}$ & 1 & -6 & 10 & 36 & 53 & 27 & 36 \\
\hline 013 & & $\mathrm{H} 3$ & $1-69$ & 5.44 & 15 & $1-5$ & 3.48 & 10 & 1.26 & & $\frac{1}{7}$ & 41 & 72 & 64 & 84 & 0 & 47 \\
\hline 013 & CF3 & P4(405) & $1-18$ & 7.53 & 16 & $2-14$ & 1.68 & 10 & $<0.0005$ & $\mathrm{n} / \mathrm{a}$ & $\mathrm{n} / \mathrm{a}$ & $\mathrm{n} / \mathrm{a}$ & $\mathrm{n} / \mathrm{a}$ & $\mathrm{n} / \mathrm{a}$ & $\mathrm{n} / \mathrm{a}$ & $\mathrm{n} / \mathrm{a}$ & $\mathrm{n} / \mathrm{a}$ \\
\hline 013 & & 113 & $1-18$ & 7.53 & 16 & $2-14$ & 3.37 & 10 & $<0.0005$ & $\mathrm{n} / \mathrm{a}$ & $\mathrm{n} / \mathrm{a}$ & $\mathrm{n} / \mathrm{a}$ & $\mathrm{n} / \mathrm{a}$ & $\mathrm{n} / \mathrm{a}$ & $\mathrm{n} / \mathrm{a}$ & $\mathrm{n} / \mathrm{a}$ & $\mathrm{n} / \mathrm{a}$ \\
\hline 020 & $\overline{C F 4}$ & $\frac{17}{17}$ & $1-3$ & 5.42 & 16 & $1-39$ & 7.04 & 9 & 1.65 & $117 \mathrm{a}$ & & 41 & 67 & 57 & 49 & 13 & 76 \\
\hline 013 & CF5 & C4 & $1-69$ & 10.17 & 17 & $1-5$ & 2.12 & 8 & 2.47 & 1 & 1 & 96 & 74 & 96 & 65 & 22 & 46 \\
\hline 013 & & $\mathrm{~J} 2$ & $1-69$ & 10.51 & 17 & $1-5$ & 2.47 & 8 & $<0.0005$ & $\mathrm{n} / \mathrm{a}$ & $\mathrm{n} / \mathrm{a}$ & $\mathrm{n} / \mathrm{a}$ & $\mathrm{n} / \mathrm{a}$ & $\mathrm{n} / \mathrm{a}$ & $\mathrm{n} / \mathrm{a}$ & $\mathrm{n} / \mathrm{a}$ & $\mathrm{n} / \mathrm{a}$ \\
\hline 013 & & N2 & $1-69$ & 8.81 & 17 & $1-5$ & $\begin{array}{l}2.41 \\
2.12\end{array}$ & 8 & 1.97 & 1 & 1 & 1110 & -10 & 65 & 69 & 3 & 39 \\
\hline 020 & CF6 & $\mathrm{L} 8$ & $1-69$ & 4.07 & 13 & $1-40$ & 0.67 & 12 & 3.93 & 9 & 7 & 68 & 81 & 78 & 92 & 28 & 45 \\
\hline 020 & & $\mathrm{H} 1$ & $1-69$ & 4.41 & 13 & $1-40$ & 0.67 & 12 & $<0.0005$ & $\mathrm{n} / \mathrm{a}$ & $\mathrm{n} / \mathrm{a}$ & $\mathrm{n} / \mathrm{a}$ & $\mathrm{n} / \mathrm{a}$ & $\mathrm{n} / \mathrm{a}$ & $\mathrm{n} / \mathrm{a}$ & $\mathrm{n} / \mathrm{a}$ & $\mathrm{n} / \mathrm{a}$ \\
\hline 013 & CF7 & J8 & $1-69$ & 9.86 & 16 & $3-11$ & 1.39 & 12 & $<0.0005$ & $\mathrm{n} / \mathrm{a}$ & $\mathrm{n} / \mathrm{a}$ & $\mathrm{n} / \mathrm{a}$ & $\mathrm{n} / \mathrm{a}$ & $\mathrm{n} / \mathrm{a}$ & $\mathrm{n} / \mathrm{a}$ & $\mathrm{n} / \mathrm{a}$ & $\mathrm{n} / \mathrm{a}$ \\
\hline 013 & & J9 & $1-69$ & 10.44 & 16 & $3-11$ & 3.83 & 12 & 4.04 & 1 & 5 & 100 & 100 & 100 & 100 & 20 & 29 \\
\hline 013 & CF8 & J3 & $1-69$ & 9.22 & 17 & $2-14$ & 7.22 & 12 & 0.95 & 1 & 2 & 97 & 59 & 74 & 40 & 6 & 30 \\
\hline $\begin{array}{l}013 \\
013\end{array}$ & & $\frac{\mathrm{JS}}{\mathrm{P}(403)}$ & $\begin{array}{l}1-69 \\
1-69\end{array}$ & $\frac{9.22}{7.51}$ & $\frac{11}{17}$ & $\frac{2-14}{2-14}$ & $\begin{array}{l}3.22 \\
3.48\end{array}$ & $\frac{12}{12}$ & $\frac{1.95}{2.35}$ & $\frac{1}{1}$ & $\frac{2}{1}$ & $\frac{91}{100}$ & 44 & 78 & $\frac{40}{43}$ & $\frac{0}{5}$ & 25 \\
\hline 013 & CF9 & M11 & $1-69$ & 8.45 & 20 & $3-15$ & 3.48 & 9 & 4.04 & 1 & 2 & 100 & 39 & 59 & 56 & 25 & 49 \\
\hline 013 & & M4 & $1-69$ & 6.76 & 20 & $3-15$ & 2.44 & 9 & 2.54 & 1 & 1 & 100 & 1 & 39 & 40 & 5 & 33 \\
\hline 013 & & L3 & $\begin{array}{l}1-65 \\
1-69\end{array}$ & $\begin{array}{l}.10 \\
5.07\end{array}$ & $\frac{20}{20}$ & $\frac{3-15}{3-15}$ & $\begin{array}{l}2.44 \\
2.44\end{array}$ & $\frac{9}{9}$ & $\frac{2.04}{2.40}$ & $\frac{1}{1}$ & $\frac{1}{2}$ & 100 & $\frac{1}{18}$ & 53 & 53 & 22 & 45 \\
\hline 013 & & K11 & $1-69$ & 6.08 & 20 & $3-15$ & 2.79 & 9 & 3.97 & 1 & 1 & 100 & -17 & 47 & 44 & 14 & 33 \\
\hline 013 & & O4 & $1-69$ & 7.43 & 20 & $\frac{3-15}{3-15}$ & $\begin{array}{l}2.15 \\
2.44\end{array}$ & $\frac{9}{9}$ & $\begin{array}{l}.51 \\
1.74\end{array}$ & $\frac{1}{1}$ & $\frac{1}{1}$ & 100 & $\frac{-11}{0}$ & 40 & $\begin{array}{l}44 \\
58\end{array}$ & $\frac{14}{5}$ & 34 \\
\hline 013 & CF10 & 111 & $3-30-3$ & 3.08 & 14 & $3-15$ & $\begin{array}{l}1.77 \\
\end{array}$ & 8 & 1.61 & 2 & 3 & 84 & 10 & 31 & 57 & 14 & 22 \\
\hline 013 & & C1 & $3-30-3$ & 4.11 & 14 & $3-15$ & 3.92 & 8 & $<0.0005$ & $\mathrm{n} / \mathrm{a}$ & $\mathrm{n} / \mathrm{a}$ & $\mathrm{n} / \mathrm{a}$ & $\mathrm{n} / \mathrm{a}$ & $\mathrm{n} / \mathrm{a}$ & $\mathrm{n} / \mathrm{a}$ & $\mathrm{n} / \mathrm{a}$ & $\mathrm{n} / \mathrm{a}$ \\
\hline 013 & & G5 & $3-30-3$ & 4.80 & 14 & $3-15$ & 1.43 & 8 & $\mathrm{nc}$ & $\mathrm{n} / \mathrm{a}$ & $\mathrm{n} / \mathrm{a}$ & $\mathrm{n} / \mathrm{a}$ & $\mathrm{n} / \mathrm{a}$ & $\mathrm{n} / \mathrm{a}$ & $\mathrm{n} / \mathrm{a}$ & $\mathrm{n} / \mathrm{a}$ & $\mathrm{n} / \mathrm{a}$ \\
\hline 013 & & P2 & $3-30-3$ & 5.14 & 14 & $3-15$ & 3.90 & 8 & 4.13 & 1 & 1 & 96 & 16 & 34 & 49 & 7 & 28 \\
\hline 013 & & A7 & $\begin{array}{l}3-50-5 \\
3-30-3\end{array}$ & $\begin{array}{l}.14 \\
10.27\end{array}$ & $\frac{14}{14}$ & $\frac{3-15}{3-15}$ & $\begin{array}{l}4.90 \\
4.26\end{array}$ & $\frac{0}{8}$ & $\begin{array}{l}4.15 \\
2.16\end{array}$ & $\frac{1}{1}$ & $\frac{1}{2}$ & 97 & 30 & $\begin{array}{l}34 \\
20\end{array}$ & 55 & 14 & $\begin{array}{l}20 \\
32\end{array}$ \\
\hline 013 & & L9 & $3-30-3$ & 5.78 & 14 & $3-15$ & 4.26 & 8 & 1.92 & & 2 & -16 & 0 & 52 & 78 & 19 & 35 \\
\hline 013 & CF11 & E9 & $3-30-3$ & 8.11 & 23 & $1-40$ & 3.43 & 10 & $<0.0005$ & $\mathrm{n} / \mathrm{a}$ & $\mathrm{n} / \mathrm{a}$ & $\mathrm{n} / \mathrm{a}$ & $\mathrm{n} / \mathrm{a}$ & $\mathrm{n} / \mathrm{a}$ & $\mathrm{n} / \mathrm{a}$ & $\mathrm{n} / \mathrm{a}$ & $\mathrm{n} / \mathrm{a}$ \\
\hline 013 & & $\frac{159}{18}$ & $3-30-3$ & $\begin{array}{l}.11 \\
8.78\end{array}$ & $\frac{25}{23}$ & $\frac{1-40}{1-40}$ & $\begin{array}{l}.45 \\
4.45\end{array}$ & 10 & $\frac{0.000}{\mathrm{nc}}$ & $\mathrm{n} / \mathrm{a}$ & $\mathrm{n} / \mathrm{a}$ & $\mathrm{n} / \mathrm{a}$ & $\mathrm{n} / \mathrm{a}$ & $\mathrm{n} / \mathrm{a}$ & $\mathrm{n} / \mathrm{a}$ & $\mathrm{n} / \mathrm{a}$ & $\mathrm{n} / \mathrm{a}$ \\
\hline 020 & CF12 & $\mathrm{E} 1$ & $3-7$ & 2.71 & 17 & $8-61$ & 2.03 & 10 & $<0.0005$ & $\mathrm{n} / \mathrm{a}$ & $\mathrm{n} / \mathrm{a}$ & $\mathrm{n} / \mathrm{a}$ & $\mathrm{n} / \mathrm{a}$ & $\mathrm{n} / \mathrm{a}$ & $\mathrm{n} / \mathrm{a}$ & $\mathrm{n} / \mathrm{a}$ & $\mathrm{n} / \mathrm{a}$ \\
\hline 020 & & F10 & $3-7$ & 4.41 & 17 & $8-61$ & 2.70 & 10 & 3.96 & 2 & 3 & -28 & -8 & 40 & 63 & 6 & 15 \\
\hline 013 & CF13 & N8 & $4-1$ & $\begin{array}{l}.41 \\
7.85\end{array}$ & $\frac{11}{18}$ & $\frac{0.01}{2-14}$ & $\frac{1.10}{6.49}$ & $\frac{10}{12}$ & $\frac{0.90}{2.55}$ & $\frac{2}{1}$ & $\frac{3}{1}$ & $\frac{-20}{99}$ & $\frac{-0}{0}$ & $\frac{40}{34}$ & $\frac{05}{61}$ & $\frac{0}{4}$ & $\frac{10}{11}$ \\
\hline 013 & & $\mathrm{~F} 4$ & $4-34$ & 5.12 & 18 & $2-14$ & 3.05 & 12 & 1.41 & 1 & 1 & 100 & 1 & 48 & 58 & 6 & 20 \\
\hline 020 & CF14 & $\mathrm{K} 2$ & $4-39$ & 2.34 & 15 & $1-5$ & 1.76 & 8 & 2.09 & 1 & 1 & -32 & 24 & 44 & 54 & 26 & 39 \\
\hline $\begin{array}{l}020 \\
020\end{array}$ & & A2 & $\begin{array}{l}4-39 \\
4-39\end{array}$ & $\begin{array}{l}.04 \\
1.67\end{array}$ & 15 & $\begin{array}{l}1-5 \\
1-5\end{array}$ & $\begin{array}{l}1.10 \\
1.41\end{array}$ & 8 & $\begin{array}{l}.09 \\
.63\end{array}$ & $\frac{1}{1}$ & $\frac{1}{1}$ & $\frac{-52}{-5}$ & $\begin{array}{l}24 \\
23\end{array}$ & $\begin{array}{l}53 \\
53\end{array}$ & 74 & $\frac{20}{20}$ & 37 \\
\hline 013 & CF15 & $\mathrm{P} 10$ & $4-59$ & 6.21 & 23 & $1-39$ & 2.11 & 8 & 0.72 & $\frac{1}{1}$ & & 25 & $\frac{25}{68}$ & 66 & 74 & 27 & 20 \\
\hline 013 & & L2 & $4-59$ & 7.29 & 23 & $1-39$ & 6.43 & 8 & 4.66 & 1 & 14 & 10 & 61 & 60 & 61 & 25 & 9 \\
\hline $3 \mathrm{H} 5-1$ & DENV2-S & cific $\mathrm{mAb}$ & $\mathrm{n} / \mathrm{a}$ & $\mathrm{n} / \mathrm{a}$ & $\mathrm{n} / \mathrm{a}$ & $\mathrm{n} / \mathrm{a}$ & $\mathrm{n} / \mathrm{a}$ & $\mathrm{n} / \mathrm{a}$ & $\mathrm{n} / \mathrm{a}$ & & 10 & nd & nd & nd & nd & nd & nd \\
\hline EDE2 B7 & DENV cross & eactive $\mathrm{mAb}$ & $3-74$ & 6.94 & 26 & $2-23$ & 4.51 & 10 & $\mathrm{n} / \mathrm{a}$ & 1 & 3 & nd & nd & nd & nd & nd & nd \\
\hline EDE1 C10 & DENV cross & eactive $\mathrm{mAb}$ & $1-3$ & 2.78 & 21 & $2-14$ & 3.82 & 10 & $\mathrm{n} / \mathrm{a}$ & nd & nd & & & 92 & & & -99 \\
\hline CR4354 & WNV-sp & cific mAb & $\mathrm{n} / \mathrm{a}$ & $\mathrm{n} / \mathrm{a}$ & $\mathrm{n} / \mathrm{a}$ & $\mathrm{n} / \mathrm{a}$ & $\mathrm{n} / \mathrm{a}$ & $\mathrm{n} / \mathrm{a}$ & $\mathrm{n} / \mathrm{a}$ & nd & nd & -127 & -57 & -149 & -139 & -48 & 0 \\
\hline
\end{tabular}

\begin{tabular}{|c|c|}
\hline $\begin{array}{c}\begin{array}{c}\text { Fold change } \\
\text { in binding }\end{array} \\
\end{array}$ & \% Neutralization \\
\hline & $\frac{90-100}{75-89}$ \\
\hline $5-10$ & $51-74$ \\
\hline $2-4$ & $\leq 50$ \\
\hline 1 & \\
\hline
\end{tabular}


bioRxiv preprint doi: https://doi.org/10.1101/790642; this version posted October 2, 2019. The copyright holder for this preprint (which was not certified by peer review) is the author/funder, who has granted bioRxiv a license to display the preprint in perpetuity. It is made available under aCC-BY-NC 4.0 International license.

Figure S2

A

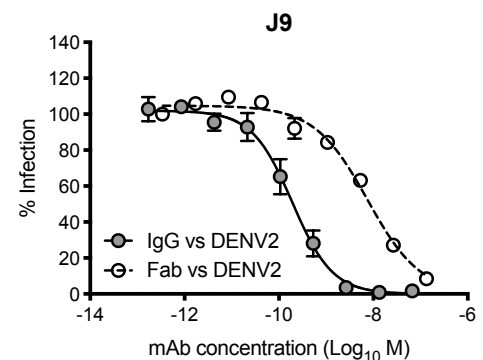

C

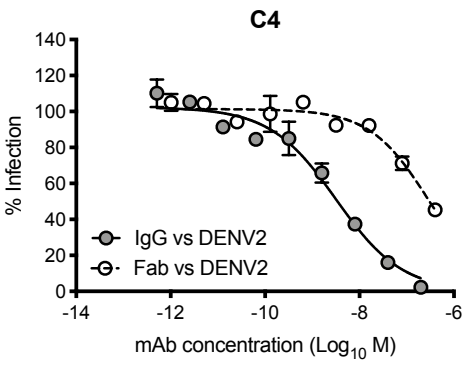

$\mathrm{B}$

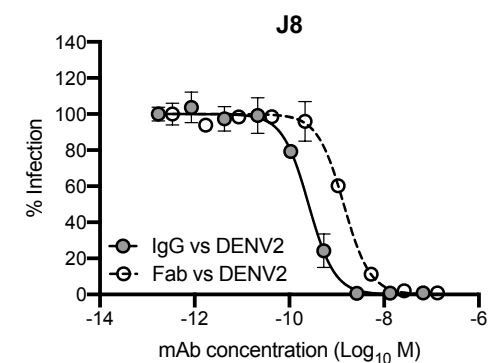

D

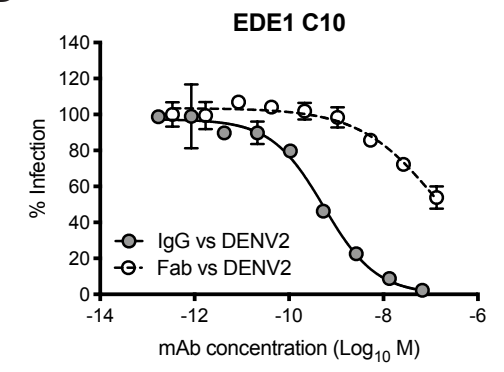

$E$

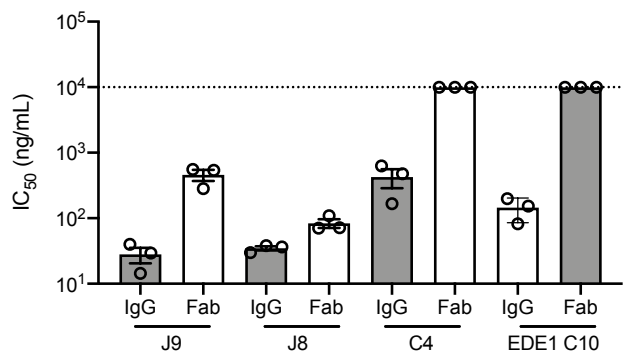




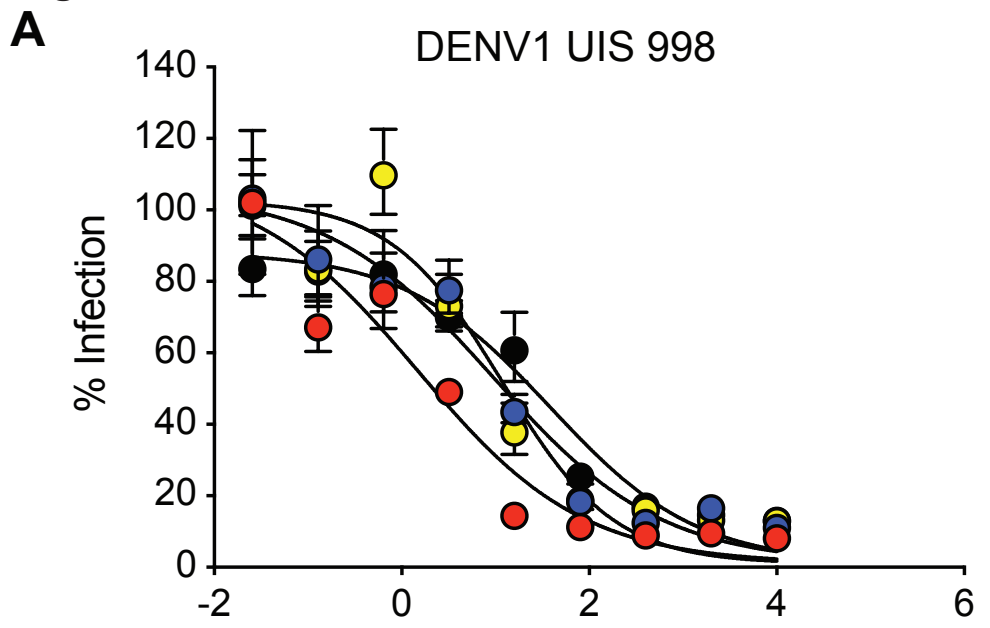

$\mathrm{mAb}$ concentration $\left(\log _{10} \mathrm{ng} / \mathrm{mL}\right)$

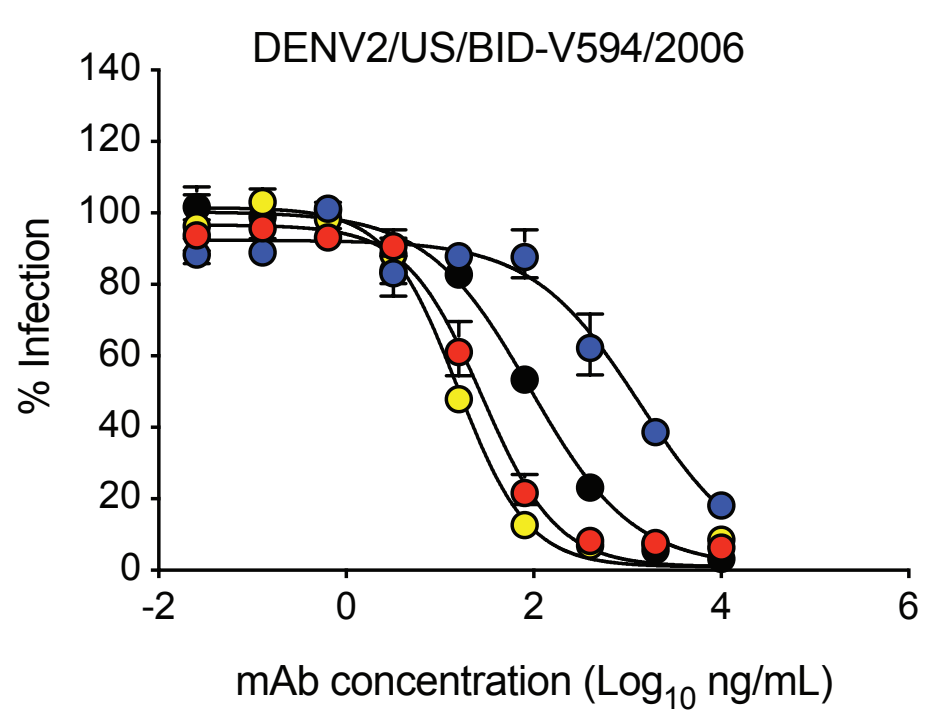

$\mathrm{mAb}$ concentration $\left(\log _{10} \mathrm{ng} / \mathrm{mL}\right)$
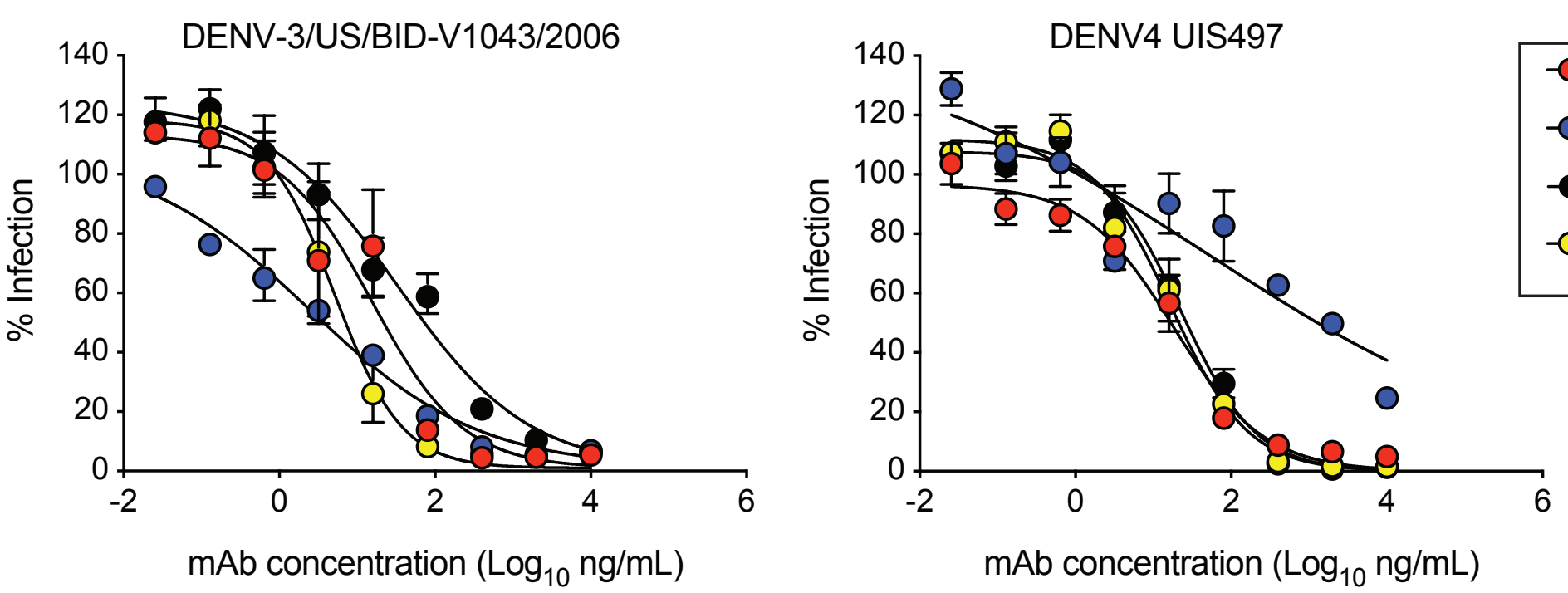

-o- $J 9$

C4

- EDE1 C10

EDE2 B7

J8

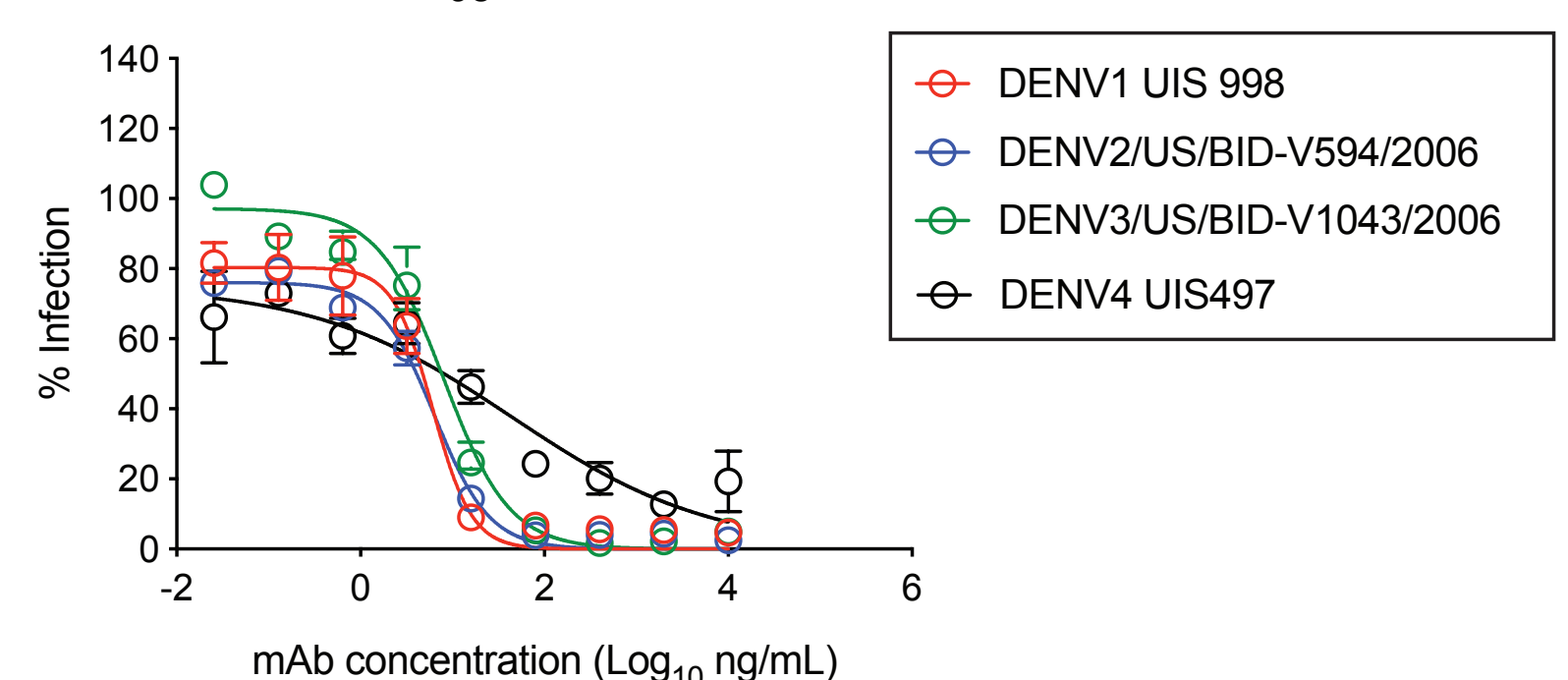

$\mathrm{mAb}$ concentration $\left(\log _{10} \mathrm{ng} / \mathrm{mL}\right)$ 
bioRxiv preprint doi: https://doi.org/10.1101/790642; this version posted October 2, 2019. The copyright holder for this preprint (which was not certified by peer review) is the author/funder, who has granted bioRxiv a license to display the preprint in perpetuity. It is made available under

Figure S4
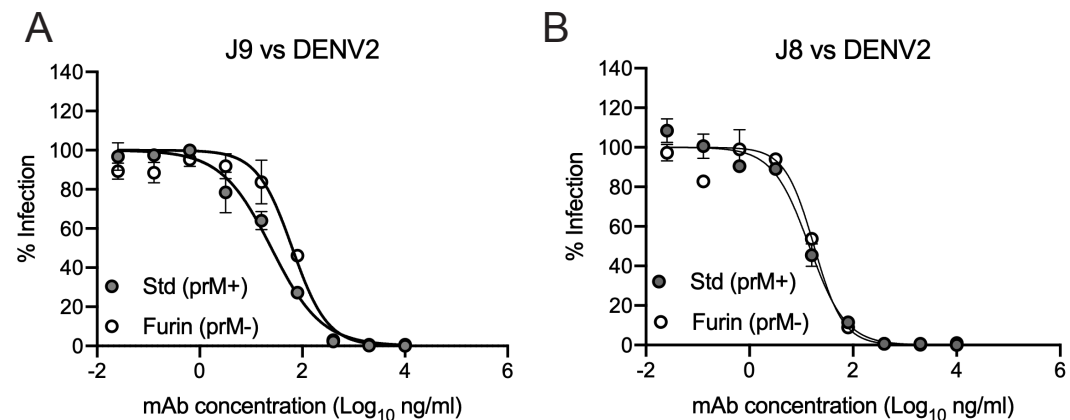

C

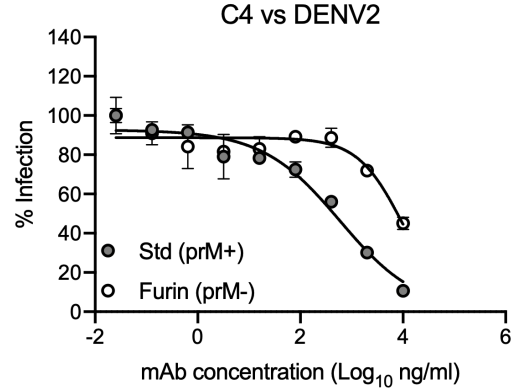

E

D
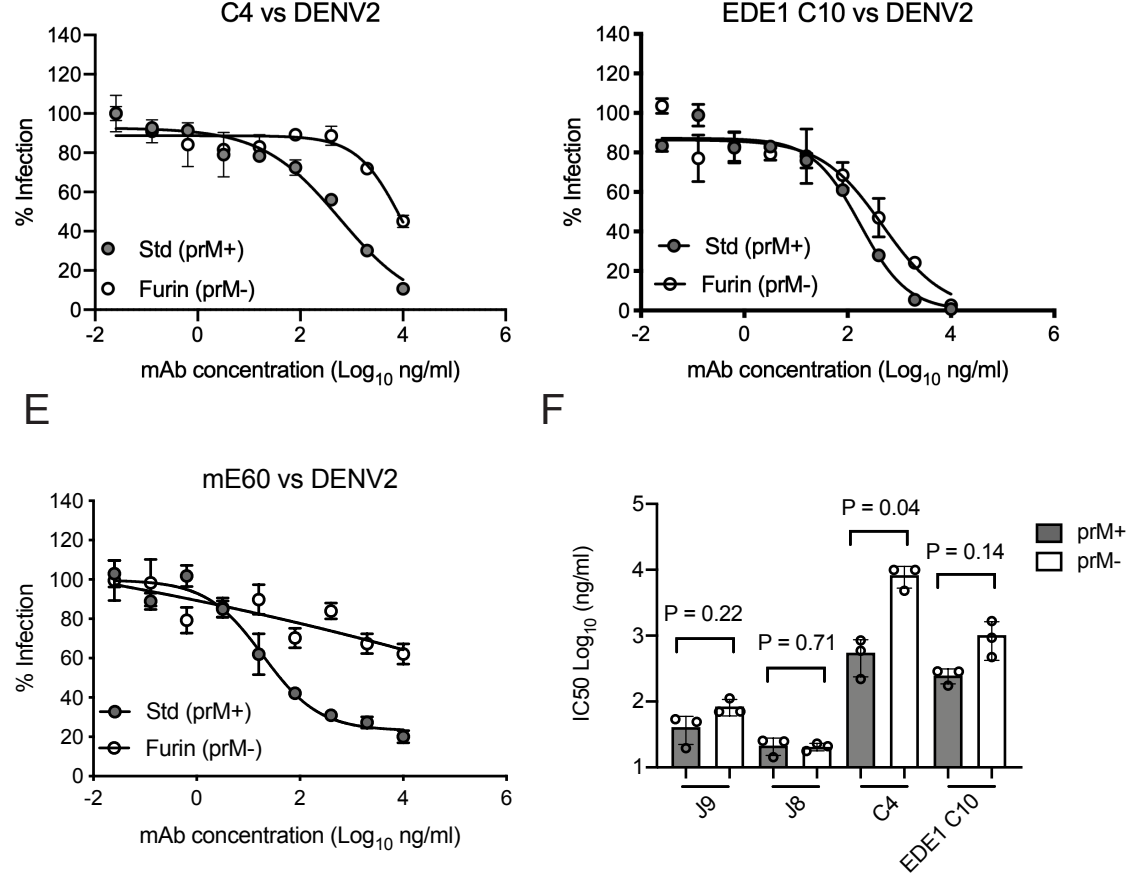
bioRxiv preprint doi: https://doi.org/10.1101/790642; this version posted October 2, 2019. The copyright holder for this preprint (which was not certified by peer review) is the author/funder, who has granted bioRxiv a license to display the preprint in perpetuity. It is made available under Figure S5

A

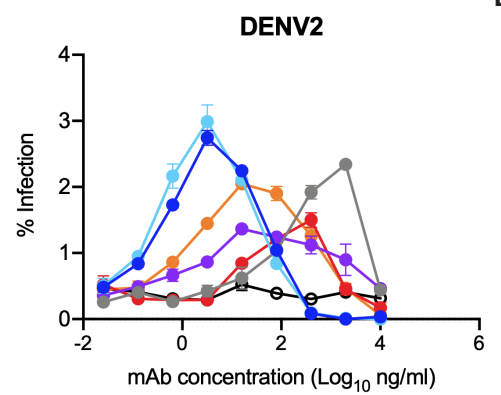

D

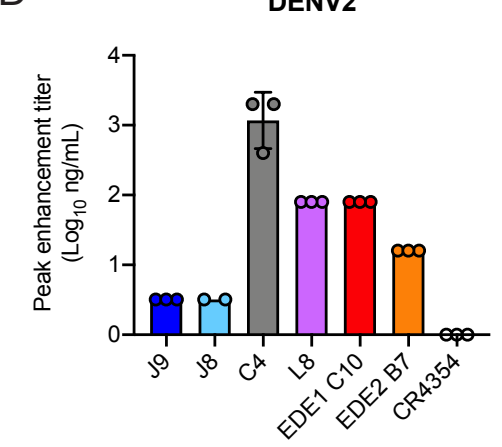

B

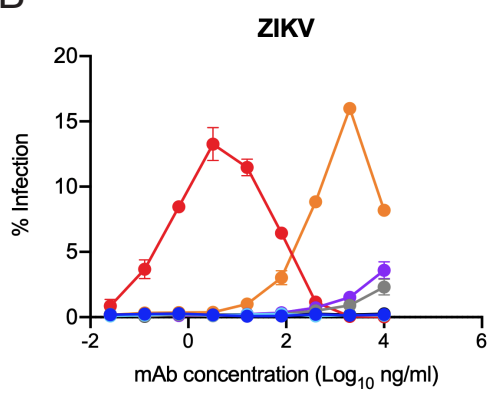

$\mathrm{E}$

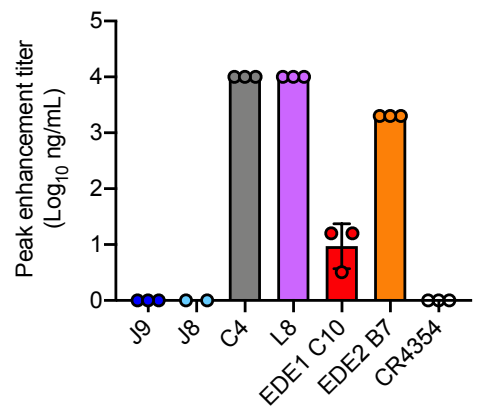

C

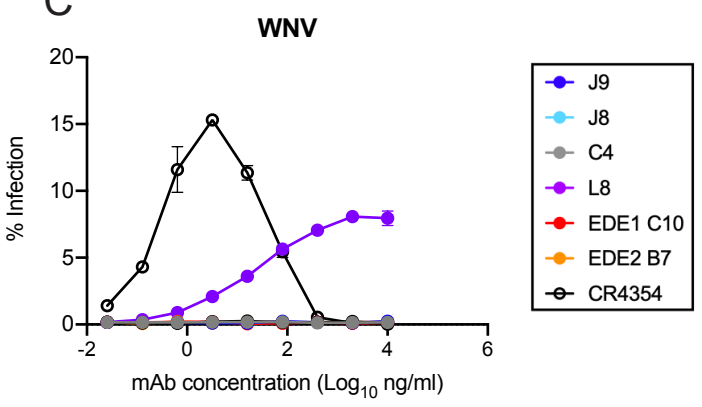

$\mathrm{F}$

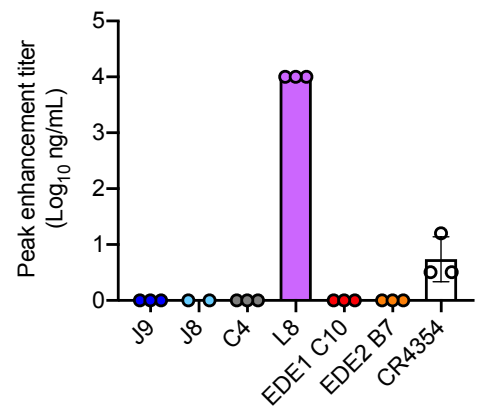


FibjoRxiv greprint doi: https://doi.org/10.1101/790642; this version posted October 2, 2019. The copyright holder for this preprint (which was not peer review) is the author/funder, who has granted bioRxiv a license to display the preprint in perpetuity. It is made available under aCC-BY-NC 4.0 International license.

A

DENV1 WP AAN06983.1 DENV2 $16 \overline{6} 81$ NP 739583.2 DENV3 CH53489 AAB69126.2 DENV4 TVP360 ANK35835.1 ZIKV HPF 2013 AHZ 13508.1 WNVI NY99 ADD23565.1 JEV_SA14_AAA2 1436.1 YFV_Asibi_AHB63685.1

DENV1_WP_AAN06983.1 DENV2 $16 \overline{6} 81$ NP 739583.2 DENV3 CH53489 AAB69126.2

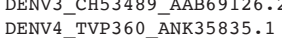
DENV4_TVP360_ANK35835.1 ZIKV_HPF2013_AHZ13508 WNVI_NY99_ADD23565.1 JEV_SA14_AAA2 1436.1

DENV1_WP_AAN06983.1 DENV2 16681 NP 739583.2 DENV3 CH53489 AAB69126.2 DENV4 TVP360 ANK35835.1 ZIKV HPF 2013 AHZ 13508.1 WNVI NY99 ADD23565.1 JEV_SA14_AAA2 1436.1 YFV_Asibí_AHB63685.1

DENV1_WP_AAN06983.1 DENV2_16681_NP_739583.2 DENV3 CH53489 AAB69126.2 DENV4 TVP360 ANK35835.1 ZIKV HPF 2013_AHZ13508.1 WNVI NY99 ADD23565.1 JEV_SA14_AAA21436.1 YFV_Asibí_AHB63685.1

DENV1_WP_AAN06983.1 DENV2_16681_NP_739583.2 DENV3 CH53489 AAB69126.2 DENV4 TVP360 ANK35835.1 ZIKV HPF 2013 AHZ13508.1 WNVI NY99 ADD23565.1 JEV SA14 AAA21436.1 YFV_Asibi_AHB63685.1

DENV1_WP_AAN06983.1 DENV2_16681_NP_739583.2 DENV3 CH53489_AAB69126.2 DENV4_TVP360_ĀNK35835.1 ZIKV HPF 2013 AHZ 13508.1 WNVI NY99 ADD23565.1 JEV SA14 AAA21436.1 YFV_Asibi_AHB63685.1

DENV1_WP_AAN06983.1 DENV2_16681_NP_739583.2 DENV3_CH53489_AAB69126.2 DENV4_TVP360_ANK35835.1 ZIKV HPF 2013 AHZ 13508.1 WNVI NY99 ADD23565.1 JEV SA14 AAA21436.1 YFV_Asibí_AHB63685.1
MRCVGIGNRDFVEGLSGATWVDVVLEHGSCVTTMAKDKPTLDIELLKTEVTNPAVLRKLC MRCIGMSNRDFVEGVSGGSWVDIVLFHGSCVTTMAKNKPTLDFFIIKTEAKOPATLRKYC MRCVGVGNRDFVEGLSGATWVDVVLEHGGCVTTMAKNKPTLDIELOKTEATOLATLRKLC MRCVGGNDFG MRCVGVGNRDFVEGVSGGAWVDLVLEHGGCVTTMAOGKPTLDFELTKTTAKEVALLRTYC IRCIGVSNRDFVEGMSGGTWVDVVLEHGGCVTVMAQDKPTVDIELVTTTVSNMAEVRSYC
FNCLGMSNRDFLEGVSGATWVDLVLEGDSCVTIMSKDKPTIDVKMMNMEAANLAEVRSYC FNCLGMGNRDF IEGASGATWVDLVLEGDSCLTIMANDKPTLDVRMINIEASOLAEVRSYC AHCIGITDRDF IEGVHGGTWVSATLEODKCVTVMAPDKPSLDISLETVAIDGPAEARKVC

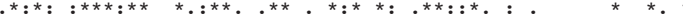
…

IEAKISNTTTDSRCPTOGEATLVEEODTNFVCRRTFVDRGWGNGCGLFGKGSLITCAKFK IEAKLTNTTTESRCPTOGEPSLNEEODKRFVCKHSMVDRGWGNGCGLFGKGGIVTCAMFR IEAKLINIUESRCPIQGEPSLEEDKRFVKR YLATVSDLSTKAACPTMGEAHNDKRADPAFVCROGVVDRGWGNGCGLFGKGSIDTCAKFA YHASVTDISTVARCPTTGEAHNEKRADSSYVCKOGFTDRGWGNGCGLFGKGSIDTCAKFS YNAVLTHVKINDKCPSTGEAHLAEENEGDNACKRTYSDRGWGNGCGLFGKGSIVACAKFT

. : : $\quad * *: * * \quad: .: \quad *:: \quad * * * * * * * * * * * * .:: * * *$
CVTKLEGKIVOYENLKYSVIVTVHTGDQ---H-----OVGNETTEHGTTATITPOAPTSE CKKNMEGKVVOPENLEYTIVITPHSGEE-H CKK CLESIEGKVVQHENLKYTVI ITVHTGDQ---H-----QVGNET--QGVTAEITPQASTVE CSGKITGNLVOIENLEYTVVVTVHNGDT---H-----AVGNDTSNHGVTAMITPRSPSVE

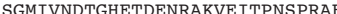
CSTKAIGRTILKENIKYEVAIFVHGPTTVESHGNYSTOVGA---TOAGRFSITPAAPSYT CTSKAIGRTIQPENIKYEVGIFVHGTTTSENHGNYSAQVGA---SQAAKFTVTPNAPSIT CAKSMSLFEVDQTKIQYVIRAQLHVGAKOENW---N---------TDIKTLKFDALSGSOE *. : : ::* : * ${ }^{*}$

IOLTDYGALTLDCSPRTGLDFNEMVLLTMEKKSWLVHKOWFLDLPLPWTSGASTSOETWN ATIDYGTVTMECSPRTGLDFNMVILOMENKAWLVHROWFIDIPI PWT AIT VKLPD ATLGGFGSLGLDCEPRTCIDFSDLYYLTMNNKHWLVHKEWFHDIPLPHA LKLGEYGEVTVDCEPRSGIDTNAYYVMTVGTKTFLVHREWFMDLNLPWSSAG---STVWR LKLGDYGEVTLDCEPRSGLNTEAFYVMTVGSKSFLVHREWFHDLALPWTSPS---STAWR AEFTGYGKATLECOVQTAVDFGNSYIAEMEKESWIVDROWAQDLTLPWOSGS---GGVWR : :* : :*. ::.:: $\quad$ : .: : :*.::* *:***. * * RODLLVTFKTAHAKKOEVVVLGSOEGAMHTALTGATEIOTSGT----TTIFAGHLKCRLK OKETLVTFKNPHAKKODVVVLGSOEGAMHTALTGATEIOMSSG----NLLFTGHLKCRLR RKELVTFKNAHAKKOEVVVLS YKE YKERVTFKVPHAKRQDVTVLGSOEGAMHSAAAGALVDSGDG-M-MHMEAGH 作 NRELLMEFEEAHATKOSVVALGSOEGGLHQALAGAIVVEYSS-S---VKLTSGHLKCRLK EMHHLVEFEPPHAATIRVLALGNOEGSLKTALTGAMRVTKDTNDNNLYKLHGGHVSCRVK$$
\cdot::^{*} \cdot{ }^{*} \quad * .^{* *} \cdot{ }^{* *} .:::^{* *}: * *
$$

MDKLTLKGMSYVMCTGSFKLEKEVAETOHGTVLVOVKYEGTDAPCKIPFSSO-DEKGVTO MDKLQLKGMSYSMCTGKFKVVKEIAETQHGTIVIRVQYEGDGSPCKIPFEIM-DLEKRHV MDKLELKGMSYMCLNTFVLKKEVSETOHGTII IKVEYKGEDAPCKIPFSTE-DGOGKA MFKTRIKGMSYTMCSGKFSIDKEMAETQHGTVVKVKYEGAGAPCKVPIEIR-DV 作 MDKLALKGTTYGMCTEKFSFAKNPADTGHGTVVIELSYSGSDGPCKIPIVSVASLNDMTP LSALTLKGTSYKMCTDKMSFVKNPTDTGHGTVVMOVKVP-KGAPCKIPVIVADDLTAAIN $:$ * $^{* * *}:$ : $^{*} \quad: \quad . \quad:: * * * * \quad: .: \quad \ldots * * * * *$ NGRLITANPIVTDKE--KPVNIEAEPPFGESYIVVGAGEKALKLSWFKKG LGRLITVNPIVTEKD--SPVNIEAEPPFGDSYI I IGVEPGQLKLNWFKKG NGRLITANPVVTKKE--EPVNIEAEPPFGESNIVIGIGDKALK INWYKKG VGRIISSTPLAENTN--SVTNIELEPPFGDSYIVIGVGNSALTLHWFRKG VGRLITANPVITESTENSKMMLELDPPFGDSYIVIGVGEKKITHHWHRSG VGRIVTVNPFSVANANA VGRLVTVNPFVSVATANAKVLIELEPPFGDSYIVVGRGEQQINHHWHKSG VGRLVTVNPFVATSSANSKVLVEMEPPFGDSY IVVGRGDKOINHHWHKAG
KGILVTVNPIASTND--DEVLIEVNPPFGDSYI IVGTGDSRLTYOWHKEG

$$
\text { * : : : *. } \quad: *: * * *: * *:: * \quad: *^{*}:{ }^{*}
$$

60
60
60
60
60
60
60
60

120

120

120

120

120
120

120

172

172

170

177

177
177

169

232

232

230

237

234

234
226

288

288

286

288
294

291

290
286

347
347
345

345
347

347
354

351

350
345
B

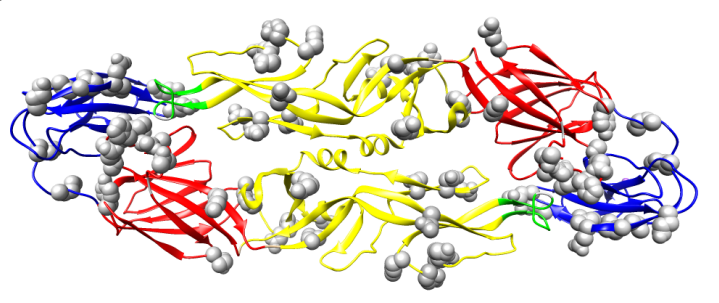

C

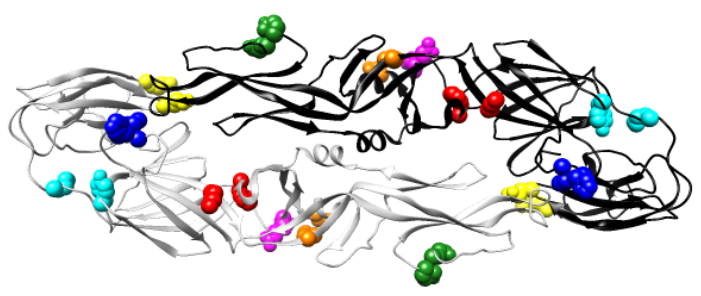




\section{Figure S7}

A aCC-BY-NC 4.0 International license.

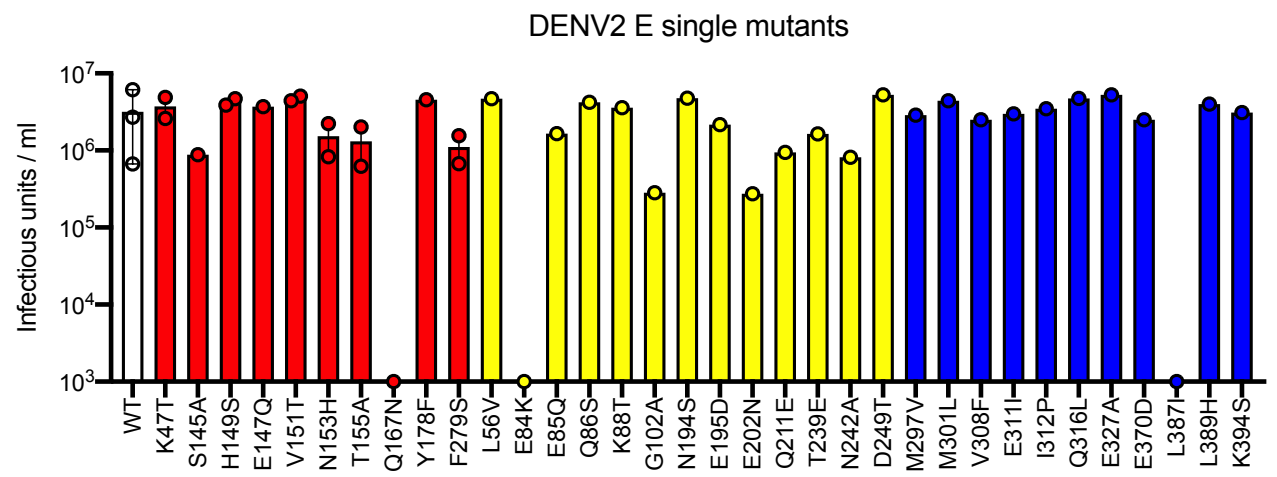

B

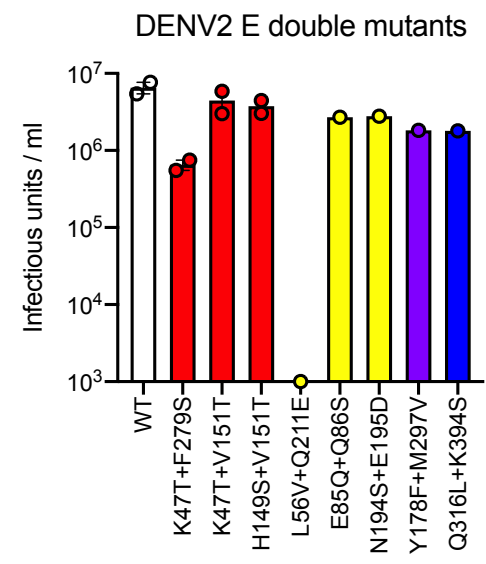


Figure $\$ 8$ xiv preprint doi: https://doi.org/10.1101/790642; this version posted October 2, 2019. The copyright holder for this preprint (which was not

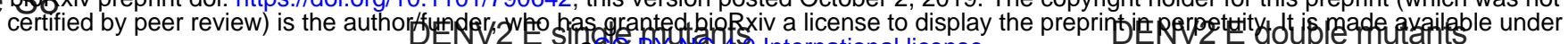

A

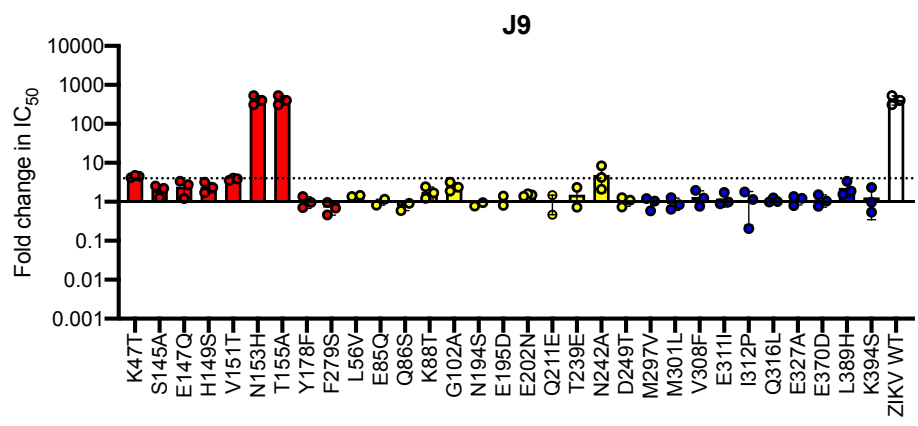

B

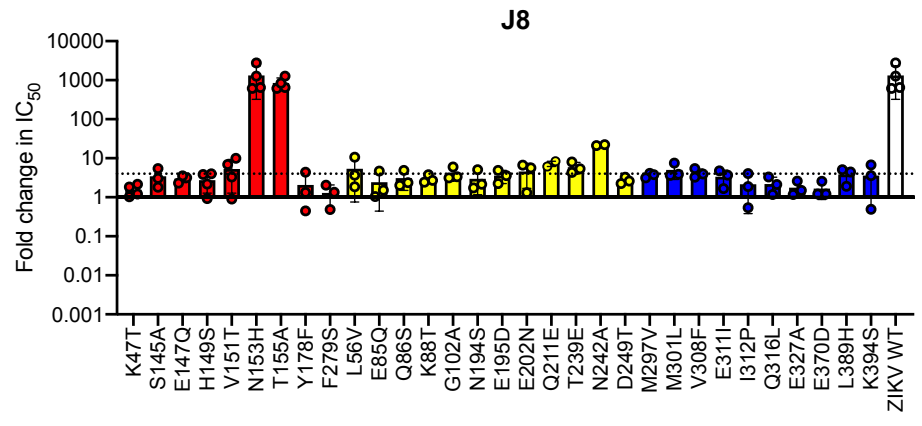

C

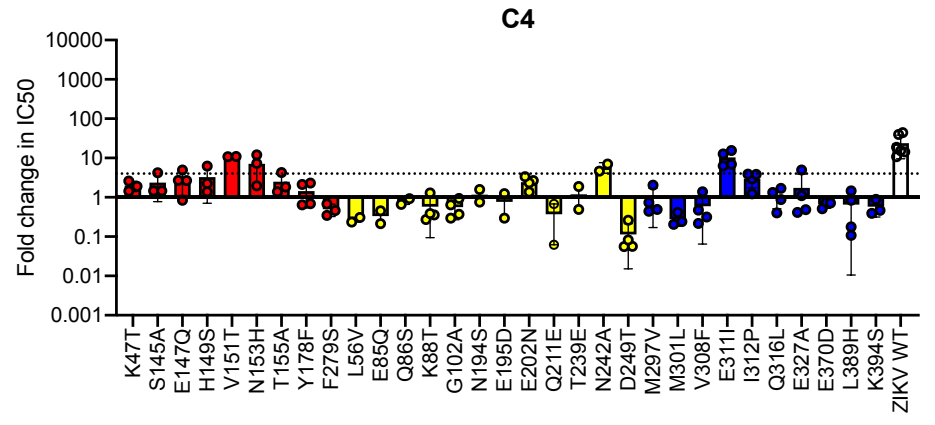

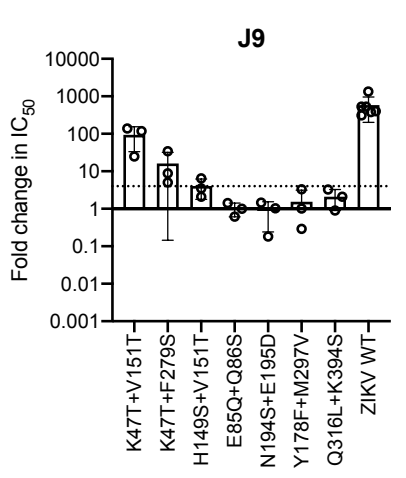
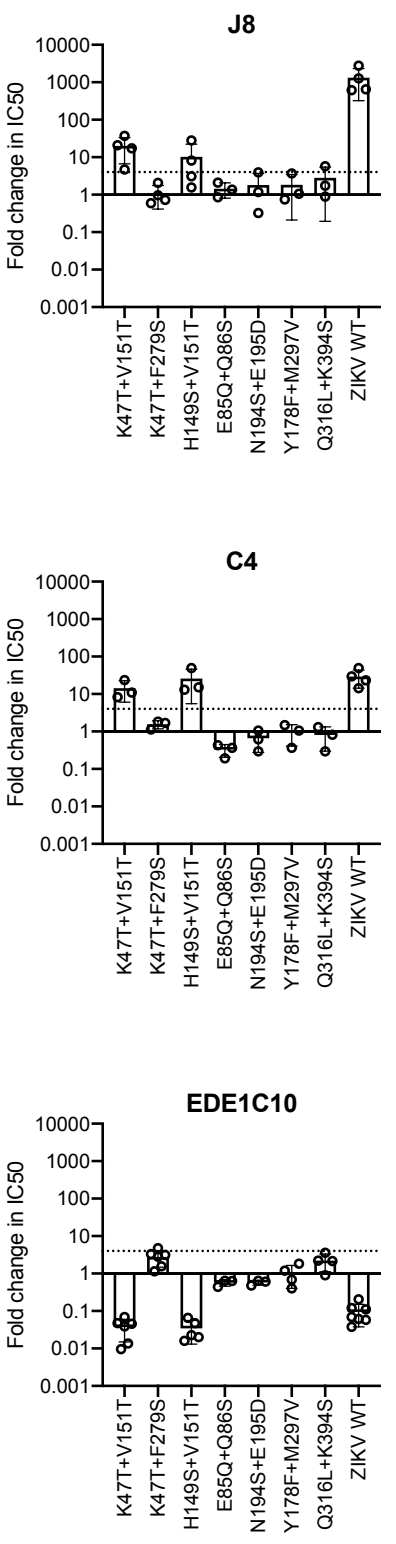

$E$

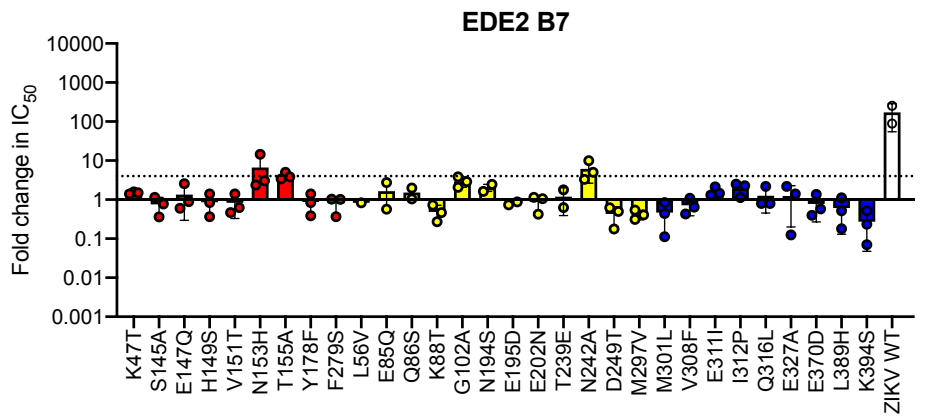

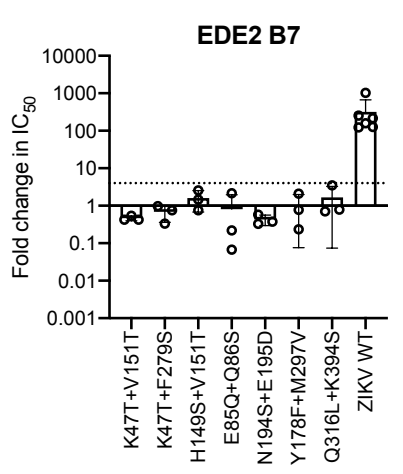



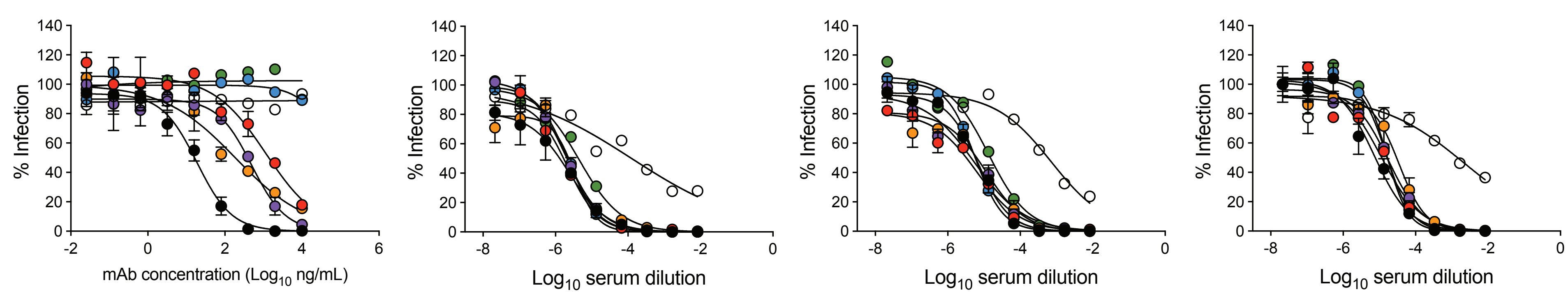

- DENV2 WT

○ ZIKV WT

- - DENV2 N47K_V151T

- DENV2 N47K_F279S

-O- DENV2 H149S_V151T

-O- DENV2 N153H

- DENV2 T155A 
bioRxiv preprint doi: https://doi.org/10.1101/790642; this version posted October 2 2019. The copyright holder for this preprint (which was not certified by peer review) is the author/funder, who has granted bioRxiv a license to display the preprint in perpetuity. It is made available under aCC-BY-NC 4.0 International license.

\section{Figure S10}

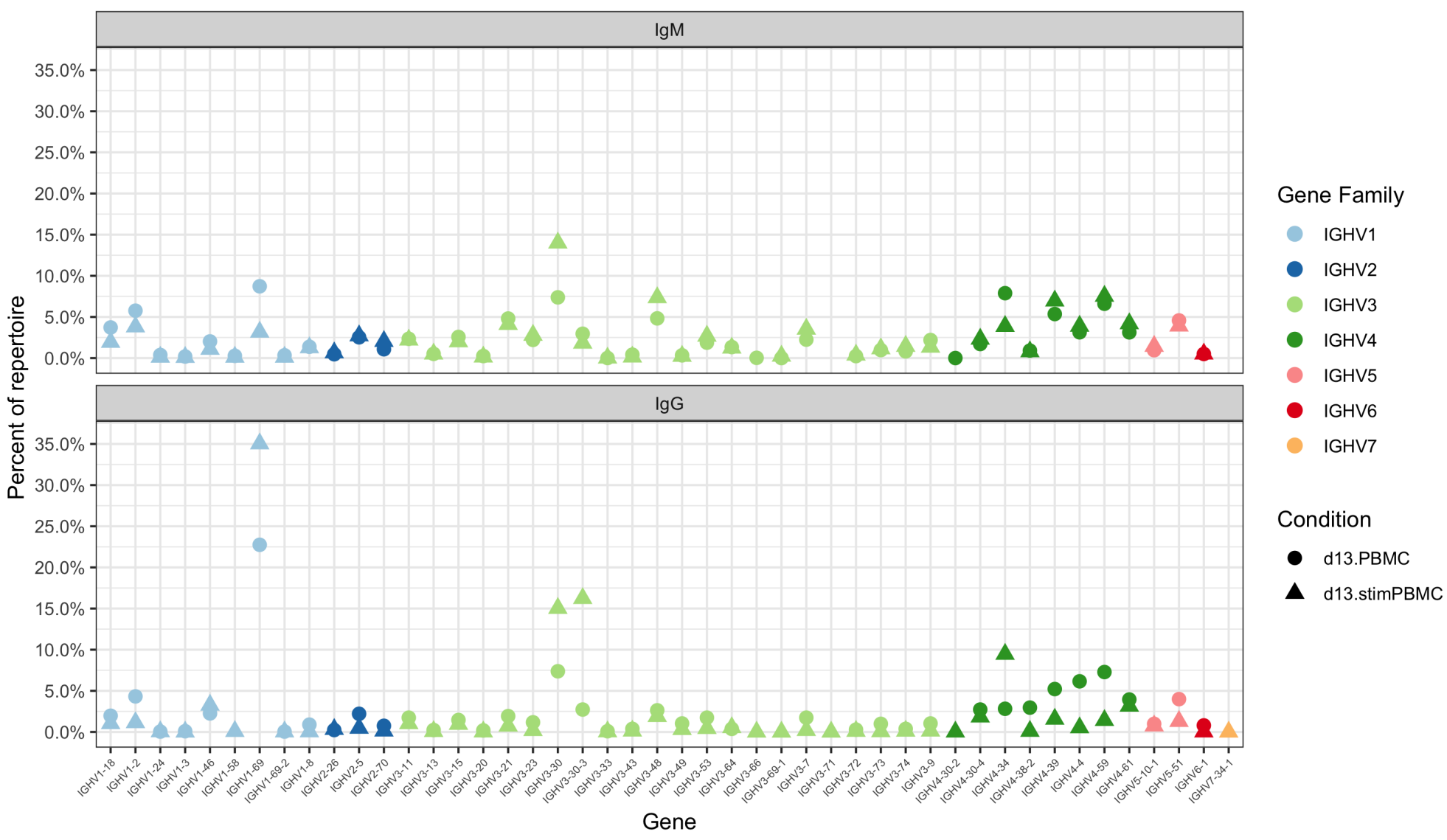


bioRxiv preprint doi: https://doi.org/10.1101/790642; this version posted October 2, 2019. The copyright holder for this preprint (which was not certified by peer review) is the author/funder, who has granted bioRxiv a license to display the preprint in perpetuity. It is made available under aCC-BY-NC 4.0 International license.

\section{Figure S11}

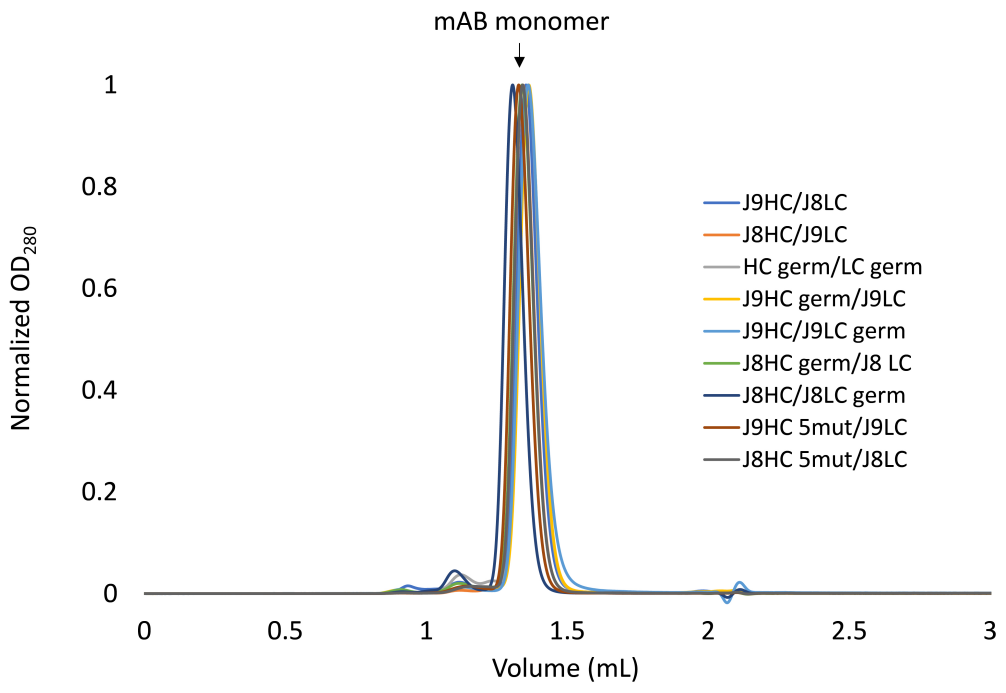

